\title{
BEES AND HOW TO KEEP THEM
}

By C. B. GOODERHAM, B.S.A.

DOMINION APIARIST

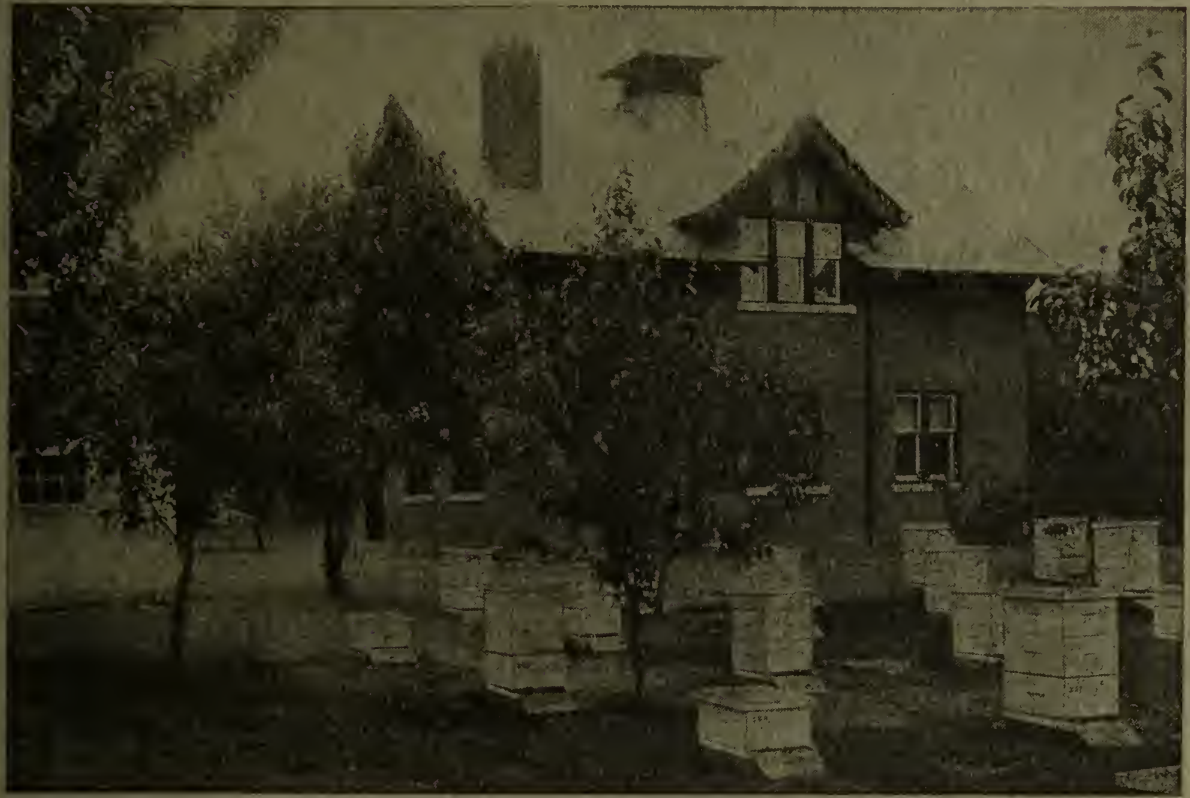

Fig. 1.-The Apicultural Building, Central Experimental Farm, Ottawa.

630.4

C212

B 33

n.s.

1923

C.2
DOMINION OF CANADA

DEPARTMENT OF AGRICULTURE

BULLETIN NO, 33-NEW SERIES

Revised from Bulletin No. 26

\section{BEE DIVISION}

DOMINION EXPERIMENTAL FARMS

Published by direction of the Hon. W. R. Motherwell, Minister of Agriculture, Ottawa, 1923 


\title{
DOMINION EXPERIMENTAL FARMS BRANCH
}

\author{
PERSONNEL
}

Director, E. S. Archibald, B.A., B.S.A.

Dominion Field Husbaadman............... E. S. Hopkins, B.S.A., M.S.

Dominion Chemist....................... Frank T. Shutt, M.A., D.Sc.

Dominion Horticulturist..................... T. Macoun.

Dominion Cerealist......................... Hewman, B.S.A.

Dominion Botanist....................... Güssow.

Dominion Animal Husbandman................... B. Rothwell, B.S.A.

Dominion Forage Crop Specialist............. G. P. McRostie, B.S.A., Ph.D.

Dominion Poultry Husbandman................ . C. Elford.

Dominion Tobacco Husbandman................ Charlan, B.Sc.

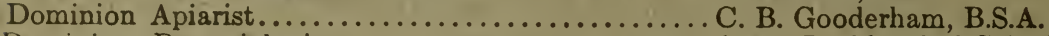

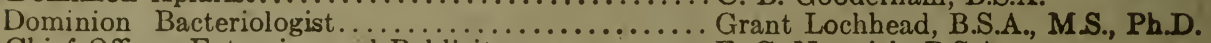

Chief Officer, Extension and Publicity ............ F. C. Nunnick, B.S.A.

Chief Supervisor of Illustration Stations............ John Fixter.

Economic Fibre Specialist.................... J. Hutchinson.

\section{ALBERTA}

Superintendent, Experimental Station, Lacombe; Alta., F. H. Reed, B.S.A.

Superintendent, Experimental Station, Lethbridge, Alta., W. H. Fairfield, M.Sc.

Superintendent, Experimental Sub-station, Beaverlodge, Alta., W. D. Albright.

Superintendent, Experimental Sub-station, Fort Vermilion, Alta., Robt. Jones.

\section{BRITISH COLUMBIA}

Superintendent, Experimental Farm, Agassiz, B.C., W. H. Hicks, B.S.A.

Superintendent, Experimental Station, Summerland, B.C., W. T. Hunter, B.S.A. Superintendent, Experimental Station, Invermere, B.C., R. G. Newton, B.S.A.

Superintendent, Experimental Station, Sidney, B.C., E. M. Straight, B.S.A.

\section{MANITOBA}

Superintendent, Experimental Farm, Brandon, Man., W. C. McKillican, B.S.A.

Superintendent, Experimental Station, Morden, Man., W. R. Leslie, B.S.A.

\section{SASKATCHEWAN}

Superintendent, Experimental Farm, Indian Head, Sask., N.D. McKenzie, B.S.A. Superintendent, Experimental Station, Rosthern, Sask., W. A. Munro, B.A., B.S.A., Superintendent, Experimental Station, Scott, Sask., M. J. Tinline, B.S.A.

Superintendent, Experimental Station, Swift Current, Sask., J. G. Taggart, B.S.A.

\section{NEW BRUNSWICK}

Superintendent, Experimental Station, Fredericton, N.B., C. F. Bailey, B.S.A.

\section{NOVA SCOTIA}

Superintendent, Experimental Farm, Nappan, N.S., W. W. Baird, B.S.A.

Superintendent, Experimental Station, Kentville, N.S., W. S. Blair.

\section{PRINCE EDWARD ISLAND}

Superintendent, Experimental Station, Charlottetown, P.E.I., J. A. Clark, B.S.A.

\section{ONTARIO}

Central Experimental Farm, Ottawa, Ont.

Superintendent, Experimental Station, Kapuskasing, Ont., S. Ballantyne.

Superintendent, Tobacco Experimental Station, Harrow, Ont., D. D. Digges, B.S.A., M.S.A.

\section{QUEBEC}

Superintendent, Experimental Station, Cap Rouge, Que., G. A. Langelier, B.Sc.A.

Superintendent, Experimental Station, Lennoxville, Que., J. A. McClary.

Superintendent, Experimental Station, Ste. Anne de la Pocatière, Que., J. A. Ste. Marie, B.S.A.

Superintendent, Experimental Station, La Ferme, Que., P. Fortier, Agr.

Superintendent, Tobaceo Experimental Station, Farnham, Que., J. E. Montreuil, B.S.A. 
Introduction $\ldots \ldots \ldots \ldots \ldots \ldots \ldots \ldots$

The Advantages of Beekeeping. . . $\ldots \ldots \ldots \ldots \ldots$

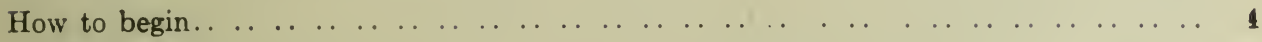

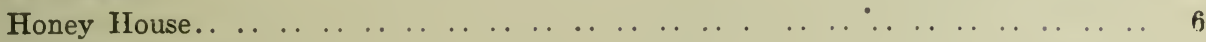

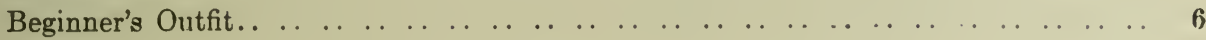

Location of the Apiary.

Races of Bees... . $\ldots \ldots \ldots \ldots \ldots$

The Bees and how they develop..

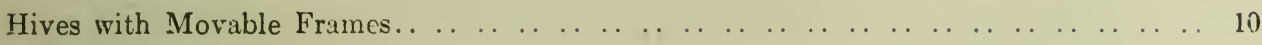

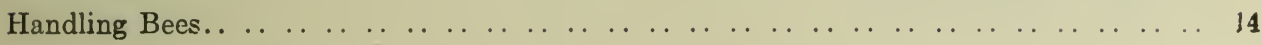

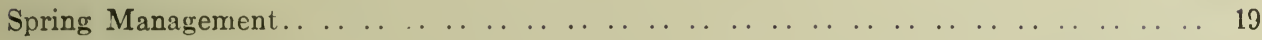

Production of Honey. . . . . . . . . . . . . . . . . . . . . . . . . . 21

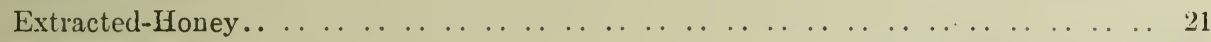

Comb-Honey. . . . . . . . . . . . . . . . . . . . . . . . . . . . . . . . . . . . . . 26

List of principal Honey Plants.. . . . . . . . . . . . . . . . . . . . . . . . . . . 28

Swarming.. $\ldots \ldots \ldots \ldots \ldots \ldots$

Swarm Control.. . . . . . . . . . . . . . . . . . . . . . . . . . . . . . . . . . . . . 36

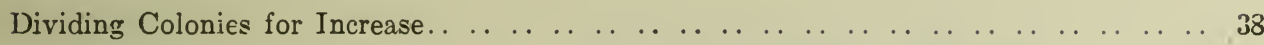

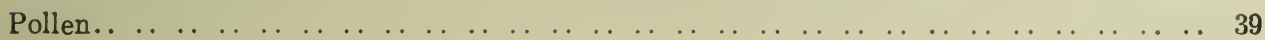

Production of $\mathrm{Wax} . \ldots \ldots \ldots \ldots \ldots$

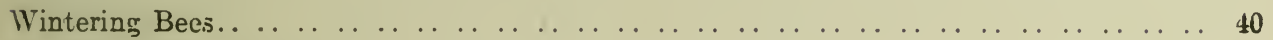

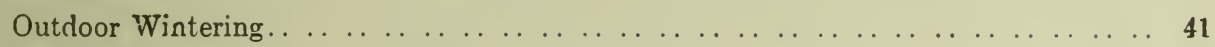

Cellar Wintering. . . . . $\ldots \ldots \ldots \ldots \ldots \ldots$

Transferring. $\ldots \ldots \ldots \ldots \ldots \ldots$

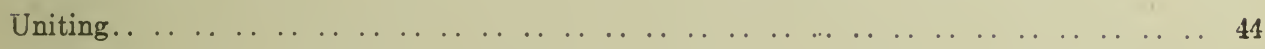

Requeening. . . . . . . . . . . . . . . . . . . . . . . . . . . . . . 46

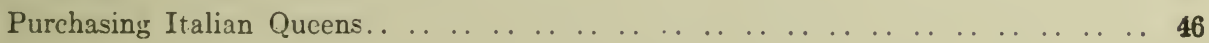

Queen introduction. . . . . . . . . . . . . . . . . . . . . . . . . . . . . . . . . 46

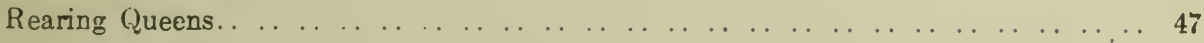

Fieeding. . 


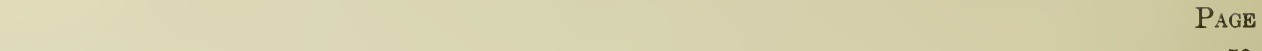

Robbing.

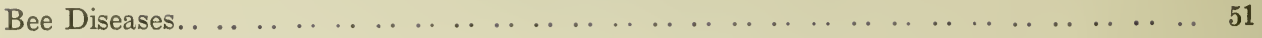

American fioul Brood. . . . . . . . . . . . . . . . . . . . . . . . . . . . . . . . . . . . . . . .

European Foul Brood. . . . . . . . . . . . . . . . . . . . . . . . . . . . . . . . . . . . . 52

Methods of Spreading Foul Brood. . . . . . . . . . . . . . . . . . . . . . 53

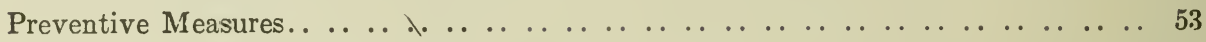

Treatment of Ameriean Foul Brood. . . . . . . . . . . . . . . . . . . . . . 54

Treatment of European Foul Brood. . . . . . . . . . . . . . . . . . . . . 55

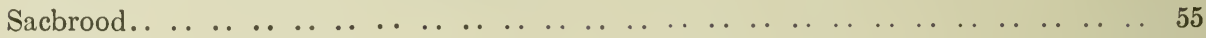

Treatment of Sacbrood.. . . . . . . . . . . . . . . . . . . . . . . . . . . . . . .

Other Affections of the Brood. . . . . . . . . . . . . . . . . . . . . . 55

Diseases of Adults. . . . . . . . . . . . . . . . . . . . . . . . . . . . . . . . . . . 55

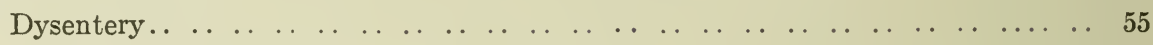

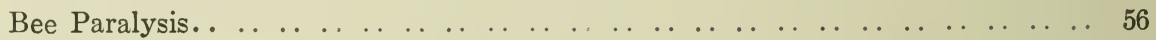

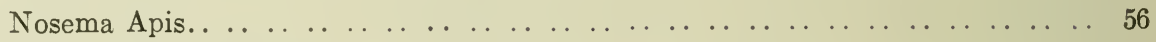

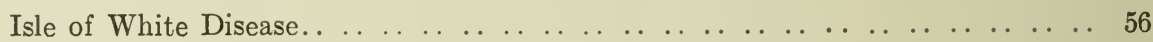

Enemies of the Bee.... $\ldots \ldots \ldots \ldots \ldots \ldots$

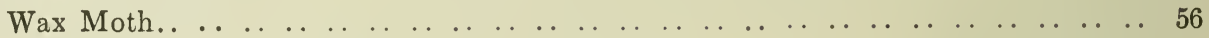

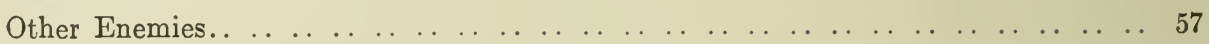

Bee Disease Legislation.

Bees and Fruit.

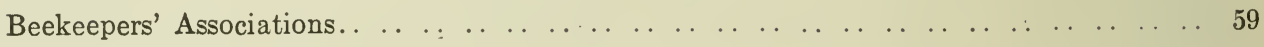

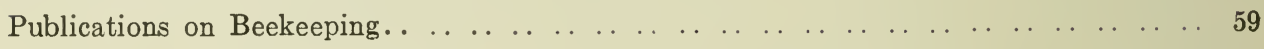

Beekeeping at the Dominion Experimental Farms... . . . . . . . . . . . . . . . . . $\quad 60$

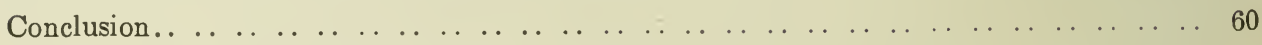




\section{BEES AND HOW TO KEEP THEM}

\section{INTRODUCTION}

The purpose of this bulletin is three fold; to point out the advantages of beekeeping; to give, very briefly, reliable advice to the beginner, and to show those who are keeping bees in an old fashioned or neglectful way how their profits may be doubled or trebled by the adoption of modern methods. Hidden in their hives, the bees seldom show any outward sign that they need attention; therefore, they are too often left to take care of themselves. The opportunities of beekeeping are not widely enough recognized and that proper management of the apiary is well repaid. There are thousands of tons of honey going to waste annually in Canada for the want of bees to gather it. Bees are not only of value for the amount of honey or wax they produce but are of equal importance to the producer of seed and fruit.

In revising this bulletin much of the original matter is retained but the greater part of it has been rewritten in order that all the information contained may be up to date.

\section{THE ADVANTAGES OF BEEKEEPING}

The saying "the resources of Canada are inexhaustible" is true of no food product more than of honey. An abundance of nectar-secreting flowers, with a high average of favourable weather for the production and ingathering of nectar, make Canada a good country for the beekeeper. Moreover, the bulk of Canadian honey is of unsurpassed quality, and has become, as it deserves to be, a staple article of food in many places, selling readily at satisfactory prices when properly distributed.

Honey has a claim to be regularly used in every home both on account of its sweetness, which is delicately flavoured according to the different kinds of flowers from which it is gathered and also because of its high food value, it being a concentrated and easily assimilated heat and energy-producing food. It also readily takes the place of sugar in cooking, preserving fruits, etc.

Throughout Canada there is an increasing number of people who make beekeeping their principal business and there are thousands who find it an auxiliary pursuit that yields no mean profit and that it combines a healthy outdoor occupation in pleasant weather with the fascinating study of an insect whose marvellous habits are a subject of absorbing interest to the nature lover.

All kinds of people keep bees-young and old, rich and poor, educated and uneducated, dwellers in the city and dwellers in the country. Among the principal vocations represented are farmers, fruit growers, clergymen, school teachers, merchants and clerks. More than one student has paid his way through college by keeping bees during the summer vacation. With a little help for the heaviest work, women frequently make successful beekeepers. Many a farmer has found that, for the small amount of capital invested and the time required to take care of them, bees will yield a larger return than anything else on the farm. In cases where the farmer or fruit grower is unable to spare time to give the proper attention to the apiary, some member of his family will frequently take charge of it with the most satisfactory results. The successful management of any apiary, however, does not require the expenditure of a large amount of time, but consists chiefly in knowing what to do and in doing it at the right time. This knowledge can only be acquired through the study of the life history and habits of the bees.

$62612-1 \frac{1}{2}$ 
The amount of honey that may be obtained from a well-managed apiary. is hard to state, because it varies with the locality, but most localities will be covered if it is put at from 50 to 150 pounds per colony in an average year. The yields also vary from year to year, principally on account of climatic conditions. In an average year a colony will far more than pay for itself in the average locality; but seasons in which the honey crop is a failure occur even in the best districts. Consequently, the prospective professional beekeeper should have sufficient capital to tide himself over a bad season or he should have some additional source of income.

Up to one hundred and sometimes two hundred colonies, can be kept profitably in a good location. Better results, however, will be obtained with a series of smaller apiaries. Commercial apiarists frequently keep one or more outapiaries, these being situated not less than two or three miles from the home apiary and from each other. The peculiar advantages of beekeeping are not sufficiently recognized. Without investing in land or expensive equipment, a man or woman who has the aptitude can learn to make money in the production and sale of an article of food which one is never compelled to sell at temporarily depressed prices, because it will keep in good marketable condition, even from year to year if necessary.

A crop of loney and a little wax do not represent all that is to be gained by keeping bees. To the fruit growers, bees may be more valuable for ensuring the crop of fruit than for honey production. It has been experimentally proved that the production of most kinds of apples, pears, plums, cherries, raspberries, gooseberries, and some other fruits, depends upon cross pollination, e.g., the transmission of the pollen from the blossoms of one variety of fruit to another by insects. 'T'he industrious and methodical honey bee is by far the most eflicient insert for this work, and in regions or seasons where wild bees are scarce, or when frequently unfavourable weather during the blossoming period demands that pollination be accomplished quickly, a few hives of bees in or near the orchard become a necessity. Bees are also useful pollinizers of several farm and garden crops. In the alsike seed growing districts the farmers are glad to have the specialist beekeeper locate his apiary near their fields because an abundance of bees increase the seed crop. Bees are also sometimes used in hot houses where cucumbers are growr.

\section{HOW TO BEGIN}

Before starting to keep bees the beginner should, if possible, spend one full season working with a good beekeeper. If one is unable to do this much may be learned by visiting neighbouring beekeepers and watching their methods of manipulating colonies. Several of the Agricultural Colleges now put on short courses in beekeeping. Some of these are given during the winter months, others during the active season.

It is a mistake to start on a large scale, as nothing is more discouraging to the beginner, after he has gone extensively into the business, than to lose most of the bees through bad wintering or some other cause, all from the want of a little experience. One or two colonies are enough to begin with. This number can be increased as experience is gained. It is a good plan to make the bees pay for themselves after the first outlay, which need not be very high.

'The best time of the year to begin beekeeping is in the spring. Colonies complete in their hives may be obtained in May-April in British Columbiaor swarms can be had during June or early July. A colony of bees obtained in the early spring will, with proper management, give a full crop of honey and one colony increase. A higher increase than this is made at the expense of the crop. A swarm is not likely to produce much honey the first year unless it is an early one. 
The colony or swarm should be fairly strong and headed with a young fertile queen. The apiary from which it comes should be free from disease. It is best, if possible, to purchase the bees in your own vicinity, one reason being that bees sent long distances may die in large numbers during transportation unless packed skilfully; another reason is that the risk of introducing disease into the district is avoided. If the colony is procured in April or May the bees will travel with less risk than in the height of summer, because there wil! be fewer bees and less honey in the hive and the weather will probably be cooler. Colonies should be moved during the autumn or early spring if the distance is less than two miles in order to avoid the return of many of the bees to the old location.

If colonies are purchased it is very desirable that they should be in modern hives. Sometimes bees can be bought very cheaply in box hives, or a colony may be found in a hollow tree. Such colonies will have to be transferred to modern hives. (See transferring).

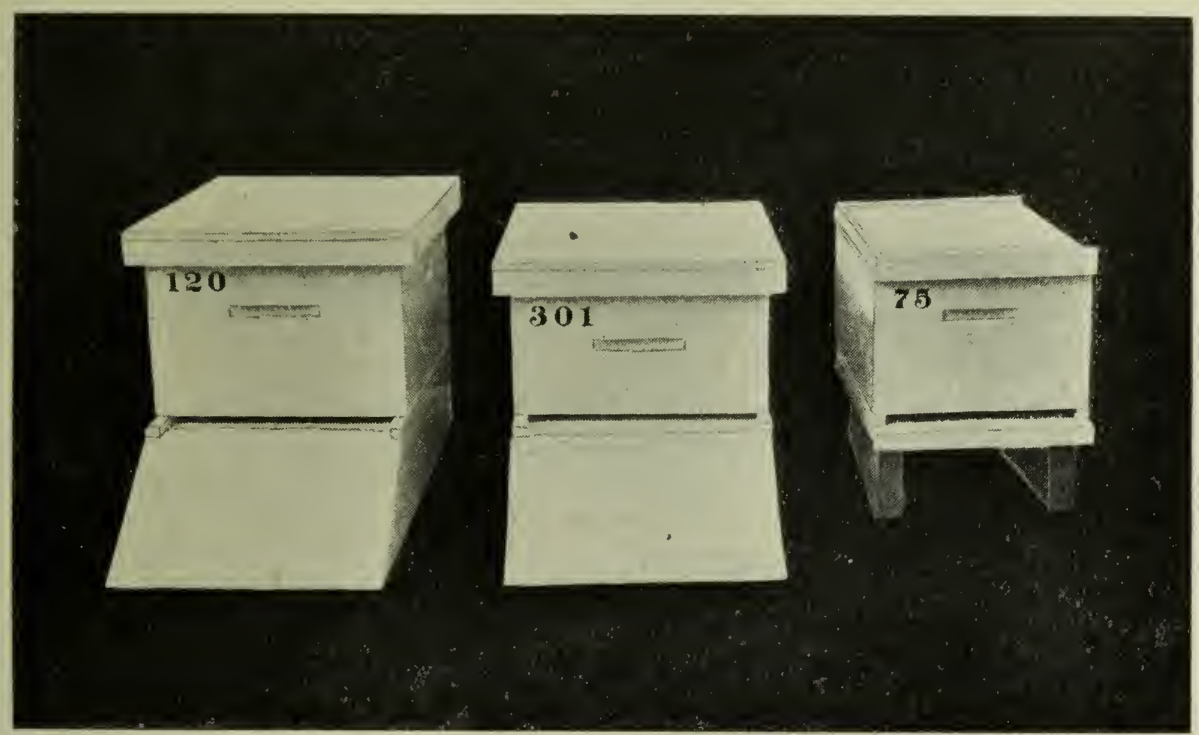

Fic. 2.-Hives-(Left) Jumbc, (Centre) 10-frame Langstroth, (Right) 8-frame Langstroth.

Another method of buying bees that is proving highly satisfactory is by weight, without combs, in boxes specially constructed for the purpose. Packed with care the bees will survive a journey lasting several days and will not be likely to carry brood diseases. Packages containing two or three pounds of bees including a tested queen are the most satisfactory. Before purchasing bees by the package, however, one should have on hand the necessary hives and other accessuries for hiving them.

Before deciding to obtain bees from places outside the province one should communicate with the Provincial Apiarist or local bee inspector, as some of the provinces have regulations regarding the movement of bees into the province.

Those who desire advice as to where bees may be procured should communicate with the secretary of the provincial or local beekeepers' association, or consult the advertising columns of the bee journals. The Bee Division, Central Experimental Farm, Ottawa, or the Provincial Department may be able to supply names of beekeepers who have bees for sale. 


\section{HONEY HOUSE}

A suitable building for the storage of supplies and combs, for making up the hives and fittings, and for the extracting and putting up the honey, is indispensable to the beekeeper. The honey house may be a simple frame structure or a more solid structure such as concrete or brick. In any case the building should be made large enough for the beekeeper's needs and absolutely bee tight. A convenient size of house for an apiary of forty or fifty colonies is 20 feet long by 15 feet wide. The floor should be firm and capable of supporting a heavy weight of honey. In a single story building it is advisable to have a raised platform for the honey tanks. The windows should be removable or sliding and the window openings covered with wire cloth with small holes at the top to allow any bees that may be brought into the honey house to escape. The door should fit closely. It is convenient to have two doors, the inner one made to swing both ways and shutting automatically. A cellar may be constructed beneath the honey house as a repository for the bees during the winter.

\section{BEGINNER'S OUTFIT}

The equipment for a beginner need not be very expensive. One should avoid purchasing unnecessary supplies but should confine himself to that which is necessary.

The following is a list of items that will be needed for making a start with two colonies of bees:-

Two colonies of bees in modern hives.

Two hives complete with frames, floor boards and covers for increase. For these two hives $2 \frac{1}{2}$ pounds of light or medium brood foundation.

One No. 1 Bee Smoker.

One Bee Veil.

One pound No. 28 tinned wire.

One spur or Electric Wire Embeddor.

One hive tool.

For Extracted Honey Production.

Six deep or twelve shallow supers fitted with frames.

Seven and one-half pounds of light brood foundation.

Two wire queen excluders.

Two bee escape boards fitted with bee escapes.

One honey extractor with 12 -inch by 18 -inch baskets.

Uncapping knives.

For Comb Honey Production.

Eight comb honey supers.

About 300 sections.

Four pounds thin foundation.

Two wire queen excluders.

Two bee escape boards fitted with bee escapes.

Prices on the above equipment can be obtained from the manufacturers' catalogues, which can be had free upon application.

\section{LOCATION OF THE APIARY}

It has been remarked that the quantity of honey that bees will gather varies considerably in different places. There are, however, few places in Cianada that will not yield enough to make beekeping profitable. 
While the beginner or amateur is usually limited in the choice of a location to the vicinity of his home, the man who has learned to be successful in managing bees and desires to go more extensively into the honey-producing business may find it profitable to move to a new location or to establish out-apiaries. A good location is one that will supply a fairly continuous nectar supply from spring to fall and in which one or more of the most important honey plants are plentiful within a radius of two or three miles.

In the Prairie Provinces more honey from wild flowers may be expected on the scrub and timber lands than on the open prairie.

The spot chosen for the apiary should be sheltered from high winds and especially from cold winds in the spring, which in most places are usually from the north and northwest. If the bees are to be wintered outside, protection from the wind needs special attention (see Wintering). It is also desirable to have the hives partly shaded during the hottest part of the day in summer. This can be accomplished by placing the apiary in an old orchard or on the edge of some wood lot. Planting evergreen trees or bushes in the apiary will often supply shade enough. Usually the best place for a small apiary, especially in the case of the beginner, is in the home garden from which horses and cattle are excluded by a fence, and where the hives are within sight or hearing of the house so that any swarms that may come out are seen or heard at once. The bees should not be placed near a public highway, nor where children are likely to run about in front of the hives. A valley is a better place for an apiary than a hilltop. A situation that is likely to be covered with floods should be avoided.

The ground around the hives should be kept clean, especially in front of the entrances, the grass and weeds being cut every few days.

\section{RACES OF BEES}

Two races of bees merit consideration-the black bee and the Italian bee. In the black bee the horny skin under the hair is entirely black; whereas in the Italian the abdomen is striped with yellow. The black bee was introduced into North America from Western Europe nearly three hundred years ago and has now spread all over Canada. . The Italian bee was introduced into the United States from Northern Italy in 1859. The Italian is more prolific than the black bee, gentler and less excitable under manipulation and therefore easier to handle. In regions where the summer is warm, and where most of the honey gathering takes place at a temperature above 70 degrees, it is more industrious than the black bee; but the black bee is less adversely affected by unfavourable weather in spring when the temperature hovers for long between 50 degrees and 60 degrees F., and the colonies consume less food in August. Thus it happens that the Italians are preferred by most progressive beekeepers in Ontario, western Quebec, the Prairie Provinces and the inland parts of British Columbia; while the blacks have their strongest supporters in the St. Lawrence Gulf region and in the northern part of Nova Scotia. Italians resist European foul brood much better than blacks, and in regions where this disease occurs it is necessary to keep Italians in order to make a success of beekeeping.

It is quite easy to Italianize an apiary of black bees. This is done by replacing the black queens with fertilized Italian queens, which may be purchased from a specialist in queen breeding.

Hybrids between blacks and Italians have the prolific qualities of Italians and the hardiness of blacks, and they are often more industrious than either race, but they are rather more inclined to sting. This is especially the case with the darker-coloured hybrids.

Golden Italians, in which the first three or four segments of the abdomen are clear yellow, are not, if pure, quite so hardy as three-banded Italians in which these segments are edged with black. 
Carniolan bees are sometimes recommended on account of their rapid breeding in the spring, their white-capped honey-comb, and when pure, their gentle temper, but they have the serious fault of an excessive tendency to swarm. With the larger hives now in use this may not be so serious as when smaller hives were in common use.

\section{THE BEES, AND HOW THEY DEVELOP}

A colony of bees consists normally of one queen bee, which is the mother of the colony, from 10,000 to 75,000 or more workers, which are undeveloped females specialized for a life of labour and, in the summer, a few hundred drones or males. These three kinds of individuals may be recognized by their size and shape. (See fig. 3.)

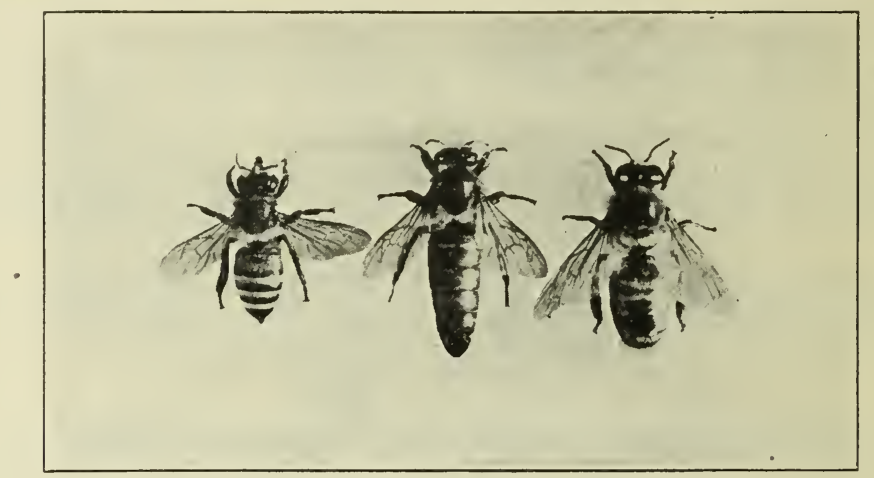

Fir. 3.-Worker bee, queen and drone.

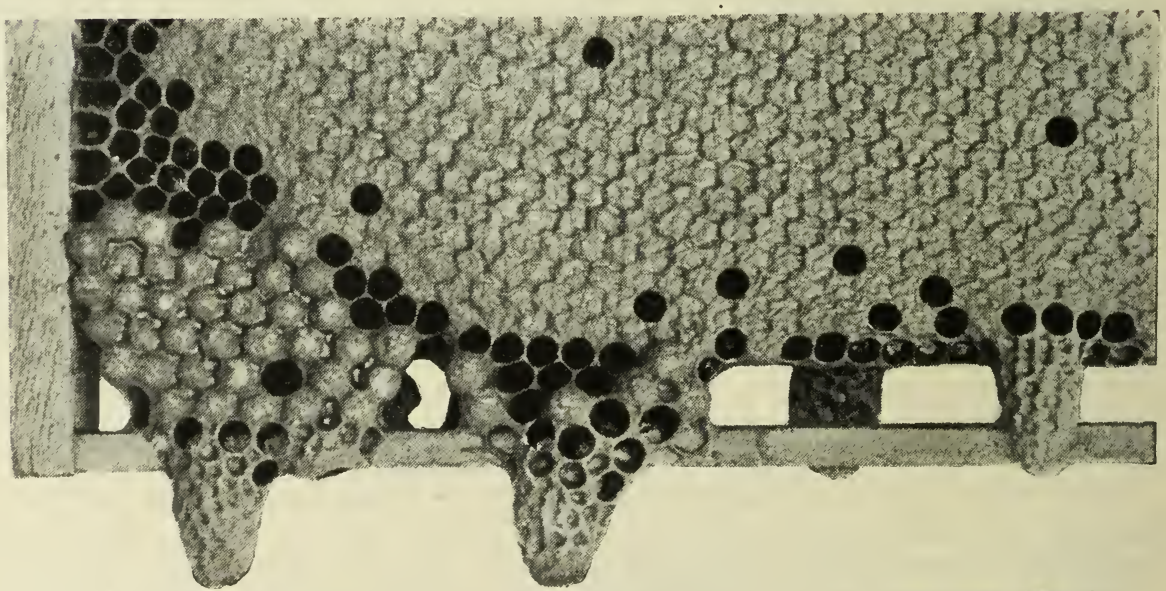

FIG. 4.-Corner of brood comb showing capped worker brood, capped drone brood and four capped queen cells.

The combs which fill the interior of the bees' dwelling are composed of wax secreted by the workers from glands situated in the under side of the abdomen, and are in the form of vertical slabs built downward from the top of the cavity or hive. Each comb consists of a dividing wall with hexagonal cells on either side. 
The honey is stored in the cells in the upper part of the combs, and in the outer combs. In the cells in the middle and lower part of the interior combs, are reared the young bees. This region of the hive is called the brood nest. Pollen is stored in the cells surrounding the young brood. The majority of the cells in the brood nest are about one-fifth of an inch in diameter, and are used for rearing the worker bees, one in each cell.

There is also a small quantity of comb consisting of larger cells measuring one-fourth of an inch aiross; in these the drones are reared. The drones are stingless and do not visit the flowers to gather honey. Their function is to fertilize the queens, for which purpose but a few are needed. The beekeeper can control the production of drones by using full sheets of worker foundation in the brood frames.

A worker bee does not commence to gather nectar until about two weeks old, and during a period of abundant nectar gathering it is worn out and dies at the age of about six weeks, but one that emerges late in the summer will live until spring. To replace the constant loss of bees and also to build up the colony after the heary loss of life during the winter and early spring, the queen must necessarily be very prolific. She commences to lay on the first signs of spring, and it has been estimated that in June a good queen will lay from two to three. thousand eggs per day. The larva or maggot hatches from the egg at the end of the third day. It is fed during the first three days on a milky food rich in protein, and then for three days upon a mixture into which a considerable amount of honey enters. On the ninth day after the egg was laid the cell is capped over with wax. Within the capped cell the larva throws off its last skin and becomes a pupa. This develops into the perfect bee, which emerges twenty-one days after the egg was laid. Sixteen days are needed for the queen and twenty-four for the drone to pass through the same stages.

The work of preparing the food for the larvæ and of feeding them is carried out chiefly by the young bees.

In the production of a queen to replace one that has died or is failing, the workers select a number of worler larvæ that have not yet been weaned from the richer food and supply them with an excess of this food, upon which the larvæ floats and feeds during the rest of its growing period. At the same time the cell containing the larva is enlarged and extended downwards to form what. is known as the queen cell, which is capped over in due time. Queen cells are also made when the bees are preparing to swarm. These are not built over young larvæ, but they take the form of inverted cups constructed on the comb, chiefly along its bottom edge and the queen lays an egg destined to develop into a queen in each. The queen usually emerges from her cell sixteen days from the time the egg was laid. As the queen will not tolerate another in the same hive, the first of the young queens to emerge will destroy the others in their cells; or, if it is in the swarming season and the colony is strong, she may lead off a swarm. Four or five days after emergence-later, if the weather is unfavourable-the queen leaves the hive for her nuptial flight. The drones follow her and one is successful at the cost of his life. The queen is impregnated for the remainder of her life, which may extend to five years, although her fertility becomes impaired, and she is consequently usually not worth keeping after the second year. If, as a result of long-continued unfavourable weather. or through injury to or malformation of her wings, or through scarcity of drones, a queen fails to get mated within about five weeks after emergence she will commence to lay eggs, but these eggs will produce drones only. Occasionally a fertilized queen that produces only or mostly drones is found. A drone-breeding queen is worthless and should be replaced. In a colony that has been long queenless, certain workers may lay eggs which, also, produce drones only. The presence of a drone-breeding queen or fertile workers may be detected before the drones actually emerge by the much raised and very convex capping of the brood. The capping of worker brood is almost flat.

62812-2 


\section{HIVES WITH MOVABLE FRAMES}

During the nineteenth century the ignorant and barbaric methods of beekeeping that had previously been in vogue gradually gave place to intelligent and humane methods, with the result that the production of the hive was greatly increased. Nothing contributed to this great change more than the adoption of movable frames for the combs. A frame hive was invented by Huber in Switzerland about 1789, and Langstroth in the United States introduced an improved type of hive with movable frames in 1852. The Langstroth hive with slight modifications is the standard hive in North America at the present time.

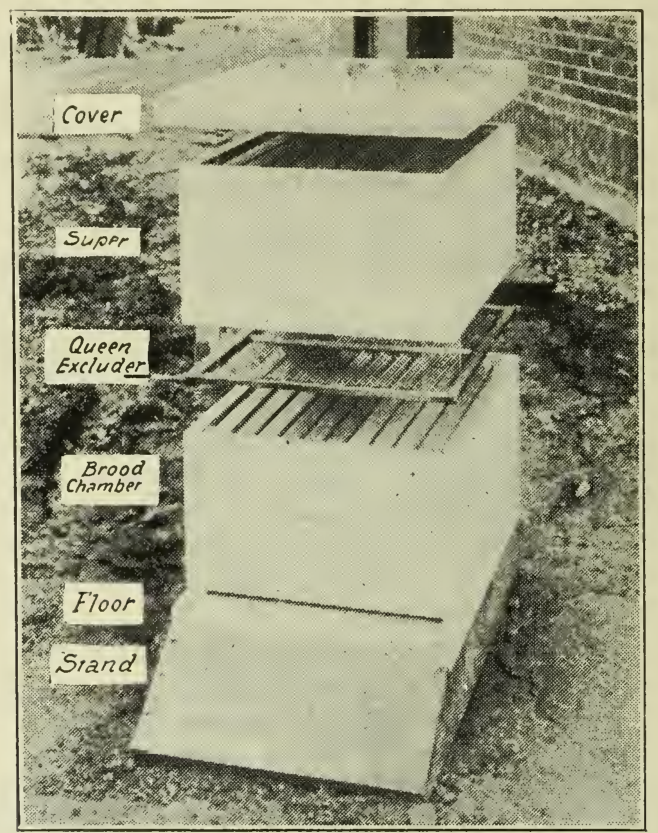

FIG. 5.-A 10-frame Langstroth hive, with upper parts separated.

Unfortunately, bees in box hives without frames are still to be found in the older settled parts of Canada, but the poor returns from, and heavy loss of bees in, such hives, due to the impossibility of making a proper examination of the combs and so discovering and supplying the bees' needs, are causing their gradual disappearance. At the present time no one who understands bees keeps them in frameless hives. The method of taking the honey that is usually employed by those who keep such hives, namely, destroying the bees by the fumes of burning sulphur or by drowning is unjustifiable destruction of valuable live stock and a relic of the barbarism of the middle ages.

The form of Langstroth hive recommended in this bulletin is shown in the accompanying engraving. It consists essentially of (1) a plain wooden box known as the hive-body or brood chamber, with (2) a loose bottom-board or floor, and (3) a cover which constitutes the roof. The frames containing the combs are suspended from rabbets in the top of the hive-body, so that they hang free in the hive and do not touch the sides or bottom, one-quarter to fivesixteenths of an inch space being left for the bees to pass around the sides of the frames and about five-eighths of an inch being left beneath the frames. In the majority of hives the last mentioned space is provided entirely in the floor section and there is a bee space of one-quarter of an inch above the frames. 
The Langstroth frame is of a certain size- $-17 \frac{5}{8}$ inches long and $9 \frac{1}{8}$ inches deep, outside measurements. This is the size most generally adopted, but frames of other sizes are used in some apiaries. The interchangeability of frames is one of the great benefits of movable frame hives, and the adoption of the Langstroth size has the great advantage that fresh supplies of these frames, together with the hives made to take them, can always be obtained from the principal dealers in beekeepers' supplies.

Four sizes of the Langstroth hive, taking $8,9,10$ and 12 frames, are in general use. The beginner is advised to adopt the 10 -frame size. The 8 or 9 -frame sizes do not provide nearly enough space in the one chamber for a prolific queen to lay her eggs, and the 12 -frame size is too cumbersome. It is well to have the hive large enough to take besides the ten frames a thin division board, also to place over the frames a quilt made of heavy duck or a honey board.

During the past few years the 10 -frame Jumbo hive has attracted a great deal of attention and is now being used by many beekeepers. This hive is of the same length and width as the 10-frame Langstroth hive but is two inches deeper. Standard floorboards and covers can be used with this hive, which is used principally for the brood chamber. Either the deep or shallow extracting supers may be used in combination with it.

Various styles of covers are made and used, but one that consists of an inner wooden cover with a space above it for about one inch of packing and with a sheet of non-rusting metal covering the top is the best. The sides and ends of this cover should telescope at least one inch over the brood chamber.

The hive should be well painted, preferably of a white colour, as a white hive does not get overheated by the sunshine.

The hive should be kept off the ground, preferably by a stand made up like a box of four rough boards, one of which forms an inclined plane extending from the entrance of the hive to the ground to act as an alighting board. The back end of the hive may be raised an inch to prevent rain running in at the entrance.

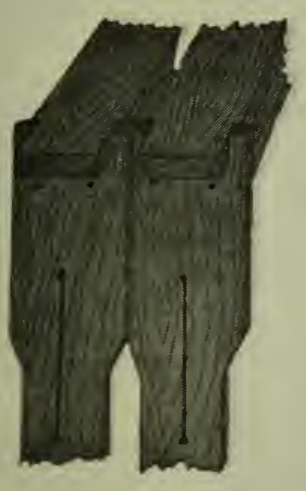

Fig. 6.-(a) Hoffman self-spacing frames.

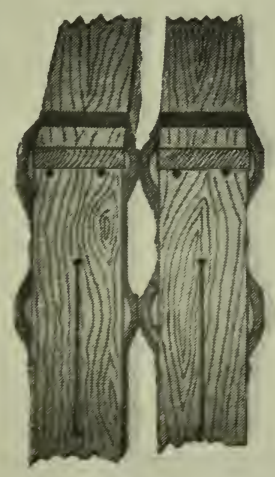

(b) Metal spaced frames.

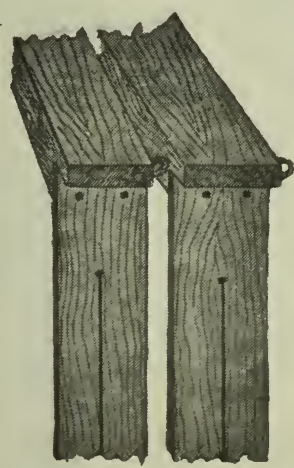

(c) Staple spaced frames.

The frames should be spaced in the hive at a distance of one and threeeighths to one and a half inches from centre to centre.

It is a great convenience to have the frames self-spacing. This may be done by driving a fine staple into each side of the top bar as shown in (c), $62612-2 \frac{1}{2}$ 
figure 6, or by metal spacing (b), figure 6, or by using the Hoffman self-spacing frame, in which the upper one-third of each end bar is widened to one and threeeighths inches, $(a)$, figure 6 . This frame will not rock when the hives are moved. In regions where the widened parts of the end bars of the Hoffman frames are liable to be firmly glued together by propolis, a resinous substance gathered by bees from the buds and stems of certain trees and used by them to fill crevices in the hive, fine wire nails should be driven into them to prevent the projections from splitting off during manipulation when the frames are separated, or the staple or metal spaced frame may be used.

In order to get the bees to build straight combs in the frames, there must be fitted into each frame, and fastened to the top bar, a sheet of beeswax, embossed with the pattern of the bases of the cells. This wax sheet is called comb foundation.

Upon the foundation the bees build out their comb, of which it eventually becomes the midrib. Full sheets of foundation should be used in each frame and these should be supported by stretching at least four horizontal wires lengthwise of the frames, threading it through holes made in the end bars. This wire should be drawn taut and firmly imbedded into the foundation by means of a spur wire imbedder (see fig. 9), or by an electric imbedder. No. 28 tinned wire should be used.

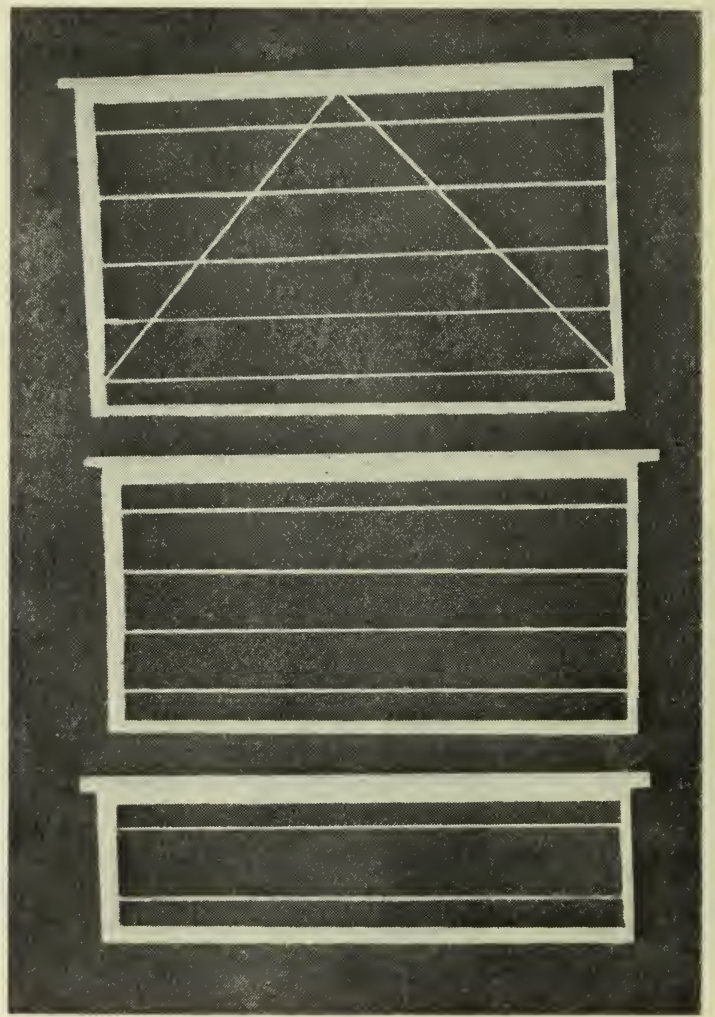

Frg. 7.-Jumbo, Langstroth and shallow frames wired ready for foundation.

The ordinary foundation sold by dealers is of the worker cell pattern and an additional advantage in using full sheets is that the production of a large force of useless drones is prevented. The frames supplied by dealers have two grooves in the underside of the top bar. In the one nearer the centre the foundation is 
placed and in the other a wooden wedge is driven to hold it tight. The top bars can also be had with only one groove into which the foundation is placed and fastened with hot wax.

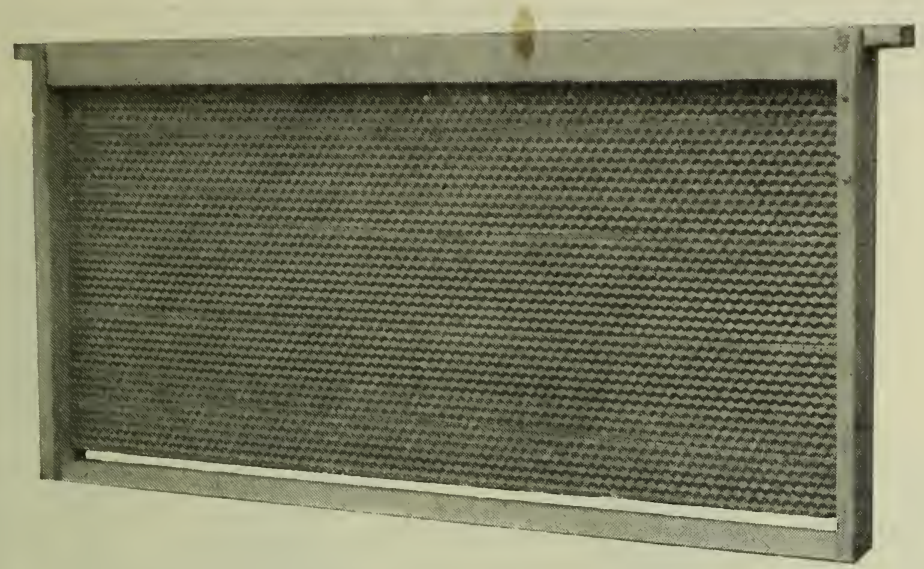

Frg. 8.-Hoffman frame with full sheet of foundation wired in.

Upon the approach of the honey flow a chamber, known as the super, to receive the surplus honey, is placed over the brood chamber. As the honey flow proceeds additional supers are usually needed.

Accuracy of dimensions in beehives and fittings is of prime inıportance, and it usually pays better to procure them from a reliable manufacturer or his agent than to make them oneself. At least a pattern hive should be so nbtained. For easy handling parts of the hive should be few, simply constructed, and as light as possible, consistent with strength and efficiency.

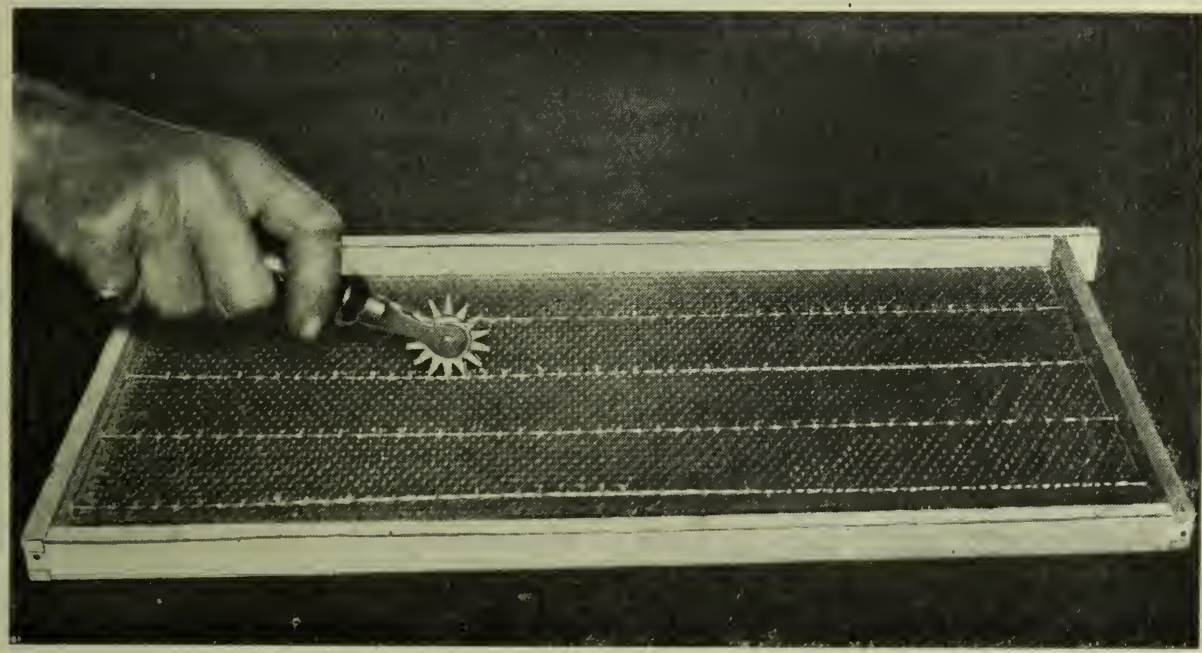

FIG. 9.-Spur wire embedder.

A sufficient supply of hives, supers, frames, foundation, etc., to cover all possible needs during the season should be ordered during the winter or early spring. The hives should be made up and painted and the frames put together and wired before the busy season. It is advisable to have the foundation shipped during mild weather, and to defer fitting it into the frames until just before these are to be given to the bees. 


\section{HANDLING BEES}

It is sometimes said that bees tolerate some people and dislike others. It would be more correct to say that they resent interference, but can be easily controlled by anybody who knows how to handle them. Fear induced by the smell of smoke and the opening up of the hives, makes the bees perfectly tractable provided they are in a active state and have not been previously irritated.

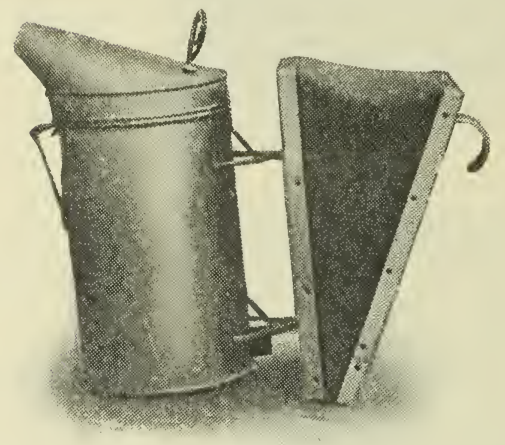

Fig. 10.-Bee Smoker.

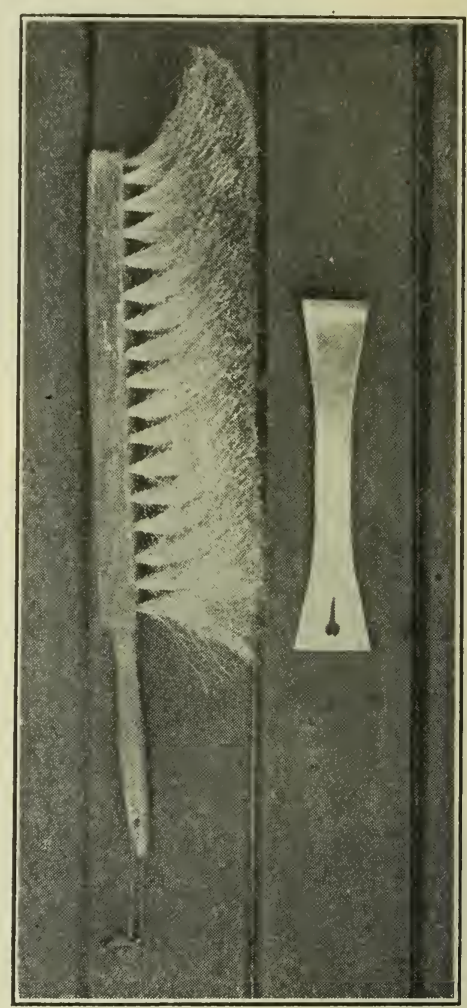

FIG. 11.-Hive Tool and Bee Brush.

I he best time to open the hive is on a fine warm day when the bees are flying freely. If possible they should not be disturbed in cold weather nor when rain threatens, and never at night. Care should be taken to avoid stings, not only because they are painful, but because the odour of the poison irritates the bees and makes them difficult to manage.

To apply the smoke a bee-smoker is required. This consists of a tin firebox attached to a pair of bellows. The best fuel for the smoker is dried cedar bark, dried rotten wood, planer shavings or pieces of old sacking. To start the smoker the firebox is opened and a small quantity of the fuel is lit and placed in the box. When, by the work of the bellows, this is well alight the remainder of the fuel is thrown in and the lid shut down. A few puffs, given occasionally, will keep the smoker alight. When not in use for a few minutes the smoker should be stood on end, as, if laid down upon its side is usually becomes extinguished.

To protect the face from possible stings, a bee-veil should be worn. The veil should be made of light and durable material, such as Brussels net. The upper end of the veil is gathered with an elastic band so as to fit closely around the crown of a broad brimmed hat. The lower end of the veil may be tucked 
inside the coat collar or held down with a string around the waist. Gloves may be worn by the beginner to create confidence, but they are more of a hindrance than a help and are seldom used by experts.

For separating frames and hive parts a hive tool, such as is advertised in supply catalogues, should be used. A screw-driver wiil serve the same purpose. A brush or large bird wing is useful for brushing the bees from their combs.

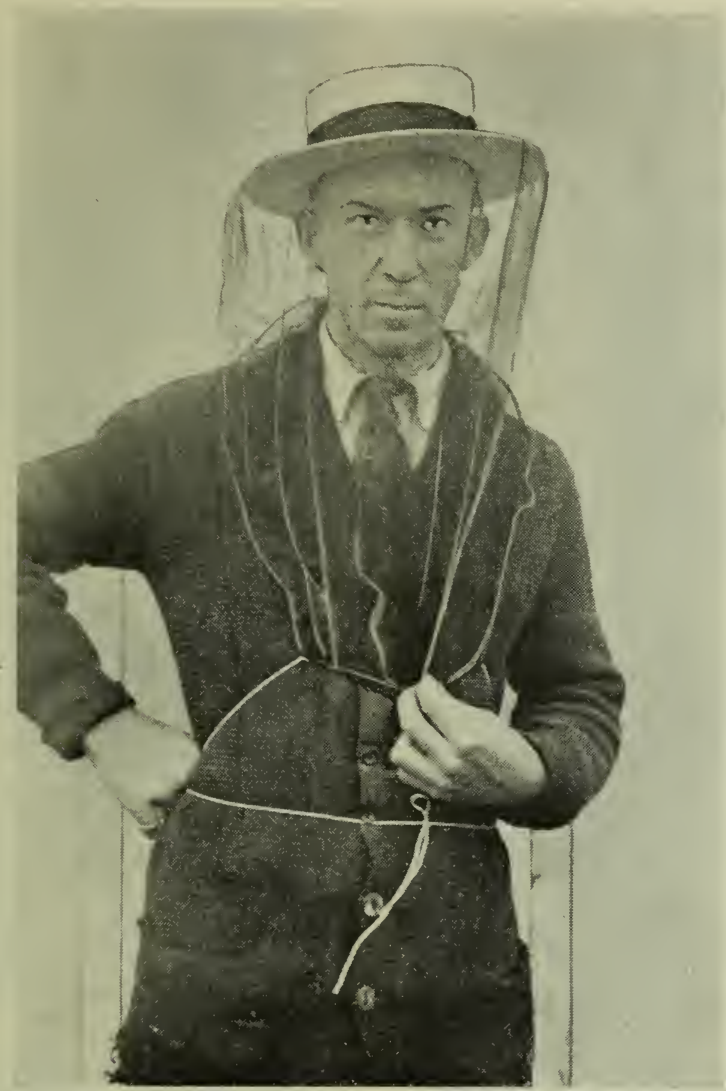

Fig. 12.-Bee Veil.

Before opening the hive have the smoker well alight and then drive a light puff or two into the entrance. Stand to one side of the hive so as not to interfere with the flight of the bees. Lift off the cover gently, turn back the quilt, and immediately direct a few light puffs of smoke downward between the frames. With the aid of the hive tool loosen and lift out the division board if one is present. The frame nearest to the operator should also be removed and stood up on end against the side of the hive taking care that the queen is not on this comb and not to crush the bees when setting it down. The other frames can now be easily removed and examined without danger of crushing the queen or bees. The work should be done quietly and as rapidly as possible, quick jerky movements being avoided. Another puff or two of smoke may be required when handling the frames, care, however, being taken not to give too much. The presence of worker brood in all stages in the central frames is evidence of the presence of a fertile queen and the well-being of the colony. The danger of the queen getting injured or getting lost by dropping off the comb should always 


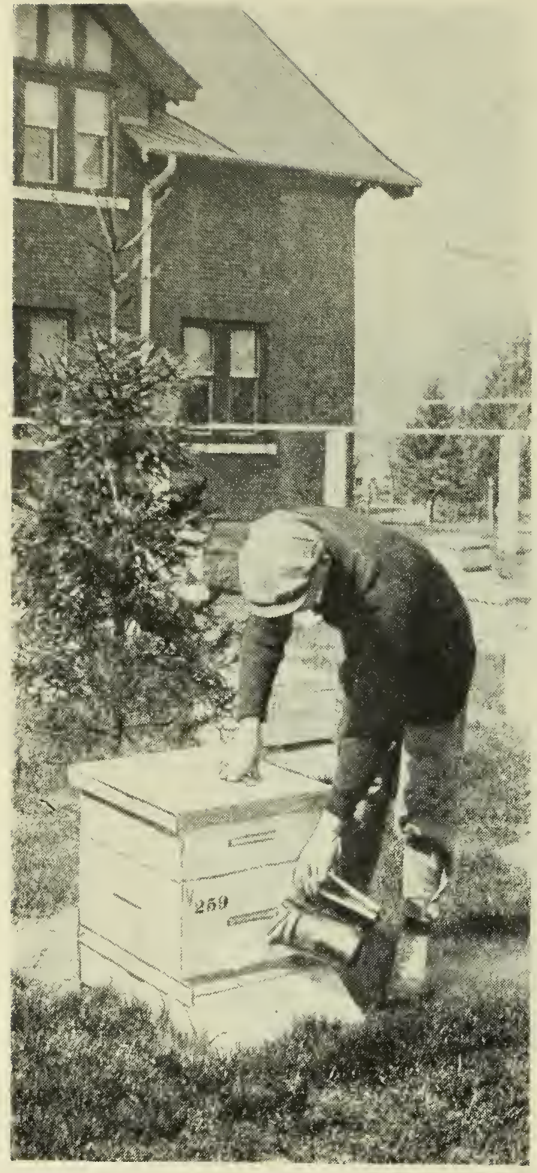

FIG. 13.-Smoking hive before opening.

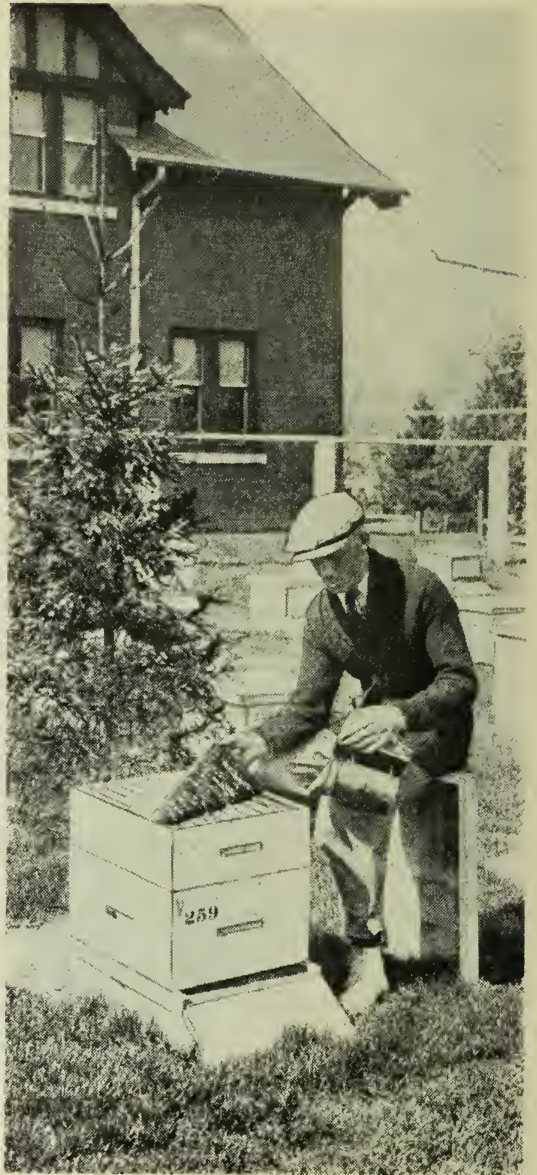

FIG. 14.-Removing quilt. 


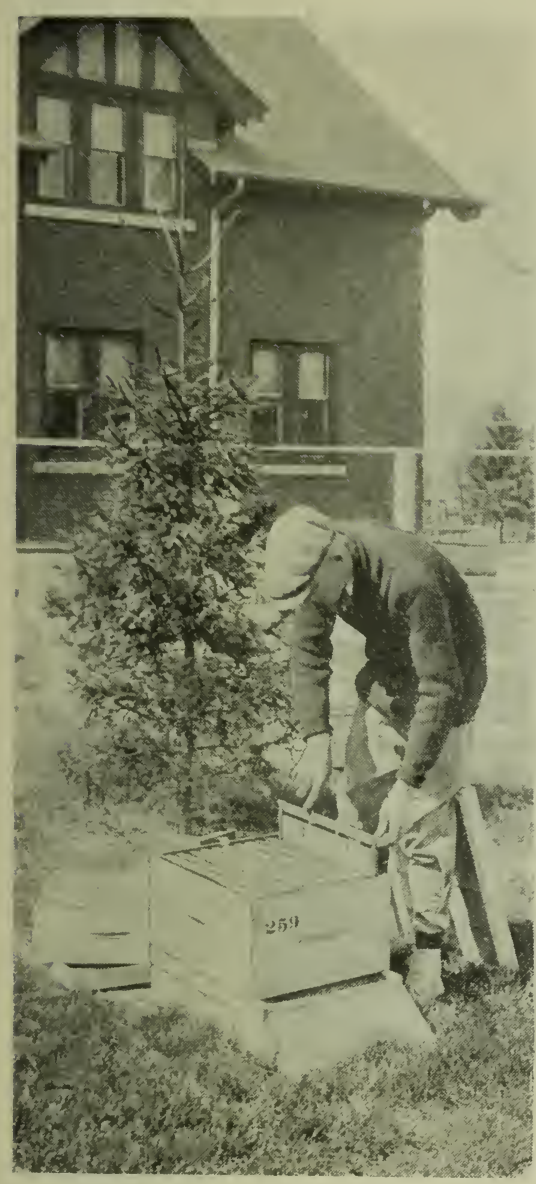

Frc. 15.-Removing division board.

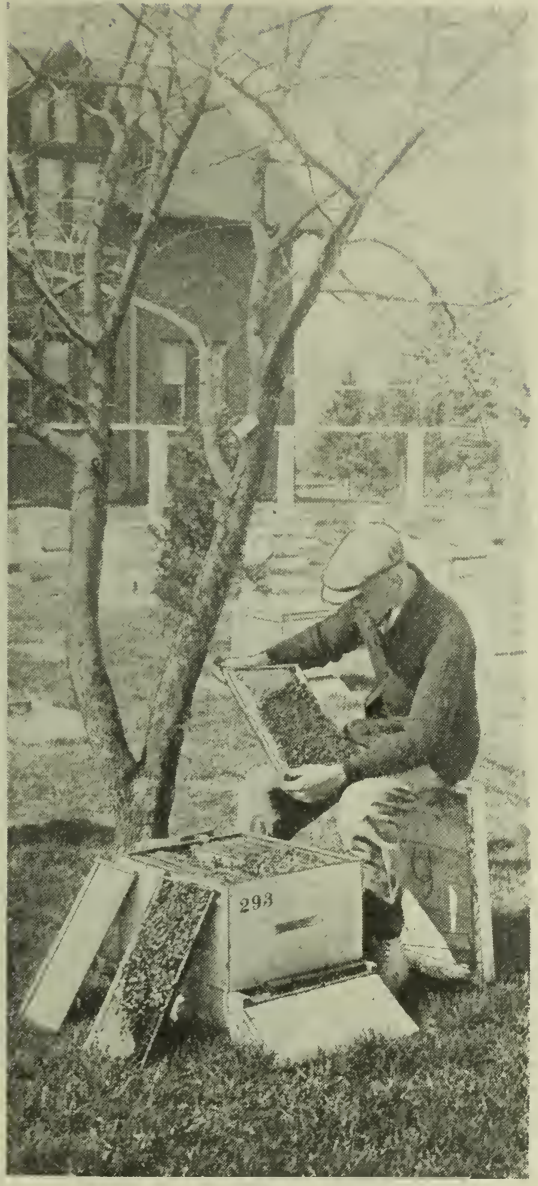

Frg. 16.-Examining comb. 
be borne in mind and guarded against. Hold the frame over the hive when examining it. Do not keep the hive open longer than is necessary; it taxes the patience of the bees and in cool weather may chill the brood. Whenever the bees show signs of restlessness a few more puffs of smoke should be given, but they should never be smoked heavily unless they have been allowed to become angry. Other things that may need to be noted are the number of combs well covered by the bees, the amount of brood present and whether it is healthy, the amount of stores and, during the honey flow, the progress of the work in the supers. It may be necessary to give a queen, to feed or to add or remove combs or supers.

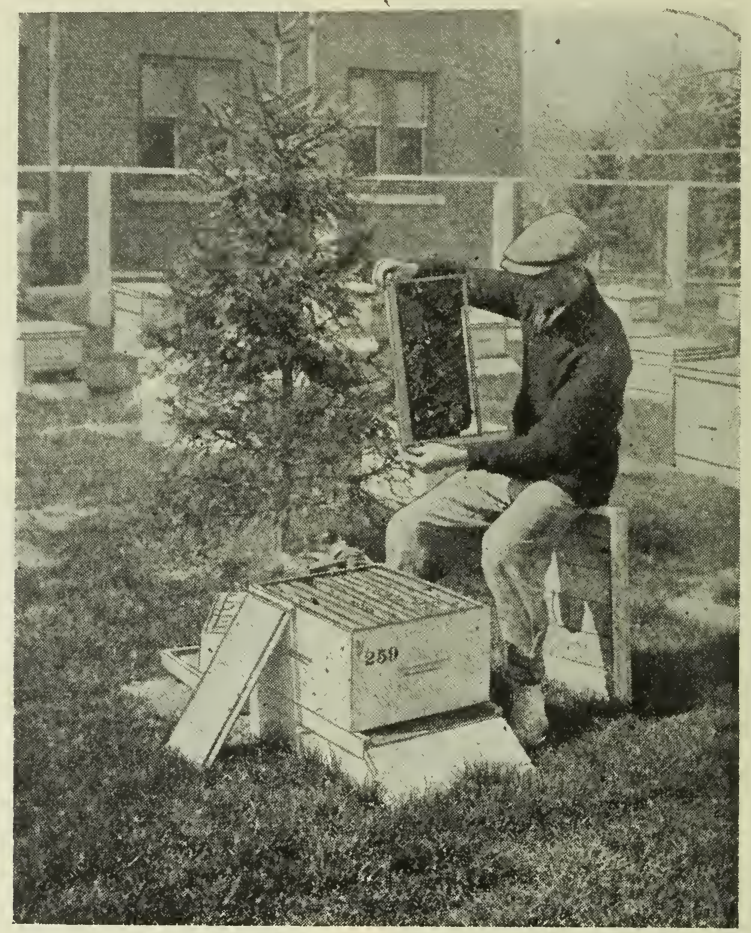

FIG. 17.-Turning the comb.

Bees need regular attention like every other kind of live stock, and this should be given in a systematic way. It is a very good plan to set apart a certain day of the week for apiary work. During the most active part of the season an examination of the colonies every eight or nine days to see if they need more room, etc., will not be too often, and it is of the greatest value in the control of swarming.

Not a few people are deterred from keeping bees by the fear of bee stings. This fear is generally unfounded. When bees are properly handled there is no risk of getting many stings. With the vast majority of people the effect of a bee-sting is one or two minutes of pain, followed by a little local swelling for a few hours or a day. Its severity usually diminishes with succeeding stings, the system gradually becoming immune by growing accustomed to the poison. In rare individuals, however, the effects of a bee-sting are more severe and prolonged, and it may sometimes cause a rash to appear over the body and difficulty in breathing. Persons who experience these symptoms should not go near an apiary. 
To minimize the unpleasant effects of a bee-sting, the sting, which is always left in the wound, should be extracted immediately, that is to say, before it has pumped in much poison. Rubbing the wound only aggravates the irritation and should be avoided. So-called sting antidotes for external application, such as solutions of ammonia and washing soda, are of practically no value, because the puncture made by the sting is so small that it closes immediately.

\section{SPRING MANAGEMENT}

Spring is an important and critical period of the bee year because it is during this season that the bees have to build up their strength, often under trying weather conditions and in a short time, in readiness for the honey flow, and also because colonies that are in bad condition may die if not attended to.

The principal object of spring management, therefore, is to get a large number of bees reared in each colony, and also later on, to prevent the tendency to swarm. For a maximum production of honey there should be, during the honey flow, an abundance of bees between the ages of two and six weeks.

If the bees have been well prepared for winter no anxiety need be felt about their condition in early spring and they are best left undisturbed for a while; but if any colonies are likely to run short of stores, or if so many bees have died in a colony that it is in danger of getting robbed out, or of perishing, a short superficial examination should be made on a warm day when the bees are flying. The weight of stores may often be estimated by lifting the hive Combs containing stores may be taken from colonies that have more than they need and given to those that are deficient, provided that no disease is present. If it is found there are not enough bees to cover two combs the colony should be united to a stronger one. It is often possible to save a weak colony by placing it on top of a strong one with a queen excluder between the two, care being taken to see that the weak colony has a little brood (taken, if need be, earlier in the day from the strong colony) to keep the bees from deserting. This work is best done towards evening and the colonies disturbed as little as possible. Two or three weeks later these colonies may be separated, moving the one containing the most brood to a new stand.

When the weather improves, a warm day, on which the bees are flying freely, should be selected for making a thorough examination of the brood nest. Evidence of the presence of a fertile queen may now be found in the appearance of worker brood. Any colony that is found to be queenless or to contain a drone-breeding queen should be united to one containing a fertile queen. Colonies may be equalized by shaking bees from the combs of strong colonies in front of the entrance of those to be helped, or by giving combs of emerging brood; of course the queen must not be included and precautions may have to be taken to avoid fighting. (See Uniting.)

Since a high temperature is needed for brood rearing, care should be taken to conserve the heat generated by the bees in the hive by providing good insulation. Colonies wintered out-of-doors should be kept in their wintering cases until settled warm weather. In most places this is not until the latter end of May or the first week in June. The amount of protection to be given to colonies that have been wintered in the cellar will depend on the spring climate and the extent of shelter from wind. In many places it pays to give special protection in the form of an outer case deep enough to cover the sides of the brood chamber and projecting several inches above it, giving room for several sacks or a chaff cushion to be placed over the bees. In exposed places and those subject to great changes in temperature it will be advisable to have the case large enough to take packing material between the hive and the case. The size of the entrance should be kept small in early spring-only an inch or two wide in the case of weak colonies.

$62612-3 \frac{1}{2}$ 
Bees need water in spring. If there is none within easy reach it should be supplied in a warm sheltered place in or near the apiary.

The building up of colonies may be seriously delayed by spring dwindling, that is, the dying of the bees that have wintered faster than the young bees can be reared. The common cause of dwindling is bad wintering, the bees having died in large numbers or become enfeebled through age or dysentry, and it is more likely to occur in coastal regions where the spring is long drawn out than in the interior where the transition from winter to summer is more rapid.

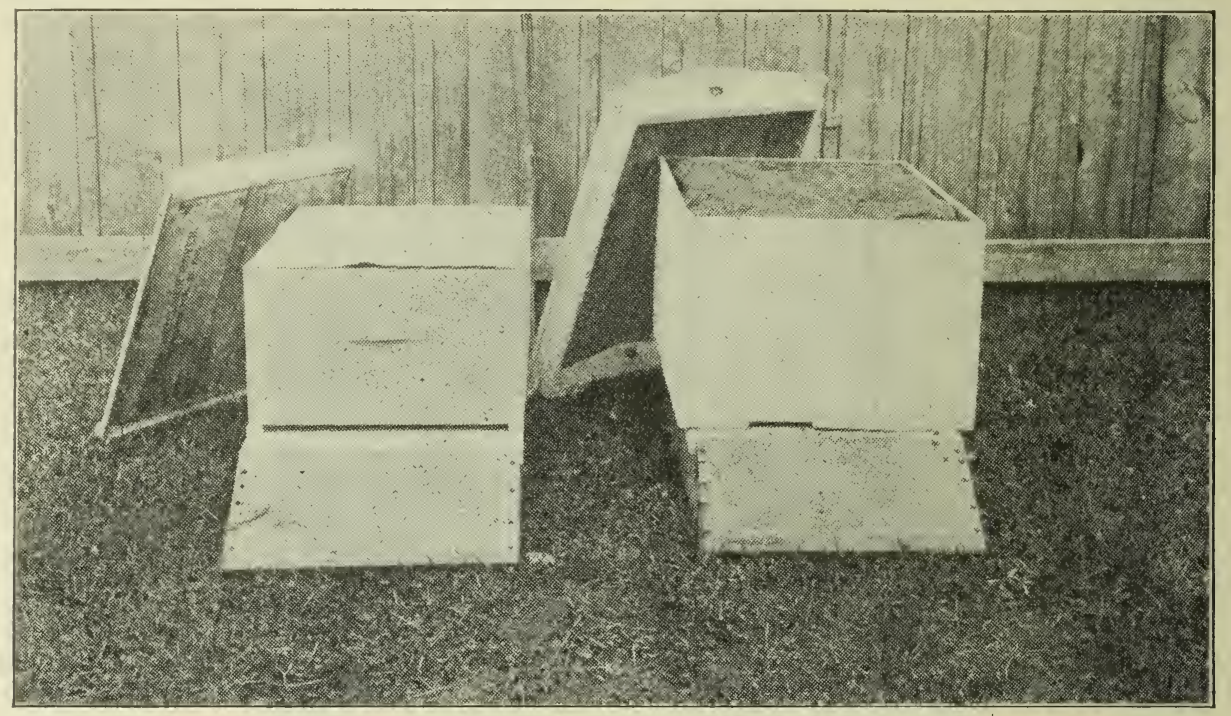

FIG. 18.-Case for light protection in spring after removal from cellar. An unprotected hive is shown on the left.

The colonies should be examined weekly, weather permitting, or fortnightly if the weather has been cool, to see that the brood nest is expanding properly, the aim being to get the bees gradually to consume the stores and replace them with brood. If stores accumulate it may be necessary to remove a portion of them and give empty comb.

The best stimulus to breeding is the natural gathering of honey and pollen in favourable weather; these are usually supplied in abundance, first by the willows and maples and later by dandelions, and, where it is plentiful, fruit bloom, as well as from a number of minor sources. In many places there is a short period of dearth between fruit bloom and the opening of the honey flow from alsike and white clover. If the weather during this period is warm and fine a little thin syrup given every evening will maintain breeding, but whether it will pay to do this depends on the duration of the honey-flow and other considerations.

Periods of inclement weather preventing the collecting of nectar may occur at any time in the spring. Short periods of this kind may be guarded against by making certain that the bees have a reserve store of a few pounds, but longer periods demand feeding to avert starvation, especially if such periods occur late in the spring or in the summer when the rate of food consumption is high. As spring advances the putting on of supers and preventing preparation for swarming will need attention. Systematic management of the apiary from this time forward is of great importance. 


\section{PRODUCTION OF HONEY}

The sources of nectar within a mile or two of the apiary should be studied so that the period and abundarce of the honey flows may be estimated and the bees may be managed to make the most of them.

The question whether it will pay better to produce extracted-honey or comb-honey needs careful consideration. In the production of extractedhoney the bees are saved the great labcur of building combs, these being emptied by means of a machine known as the honey extractor. They are then returned to the bees to be filled again and again. A colony will usually yield more extracted-honey than comb-honey, but this is balanced by the fact that the price of comb-honey is in many places much higher than that of extractedhoney. Extracted-honey is a marketable article at all seasons everywhere, is easily transported and keeps well. On the other hand, the demand for combhoney at a satisfactory price is limited, and it is somewhat fragile and difficult to keep. Comb-honey is not so easy to produce as extracted-honey, a rapid honey flow being desirable and skilful management being needed to control swarming and to get the sections finished. These considerations will lead, in many cases, to a decision in favour of extracted-honey for the bulk of the crop, but it must not be forgotten that comb-honey is a luxury that appeals to many people in a way that nothing put up in a tin can or a glass jar can do, so that it will not be wise to neglect it. The beginner will sometimes prefer to produce comb-honey in order to avoid the expense of a honey extractor the first year.

\section{EXTRACTED HONEY}

The extracting super may be of the same size as the brood chamber, taking frames of the same size, or a shallow super taking frames only $5 \frac{3}{8}$ inches deep may be used. A shallow super :s more readily occupied by the bees in the spring

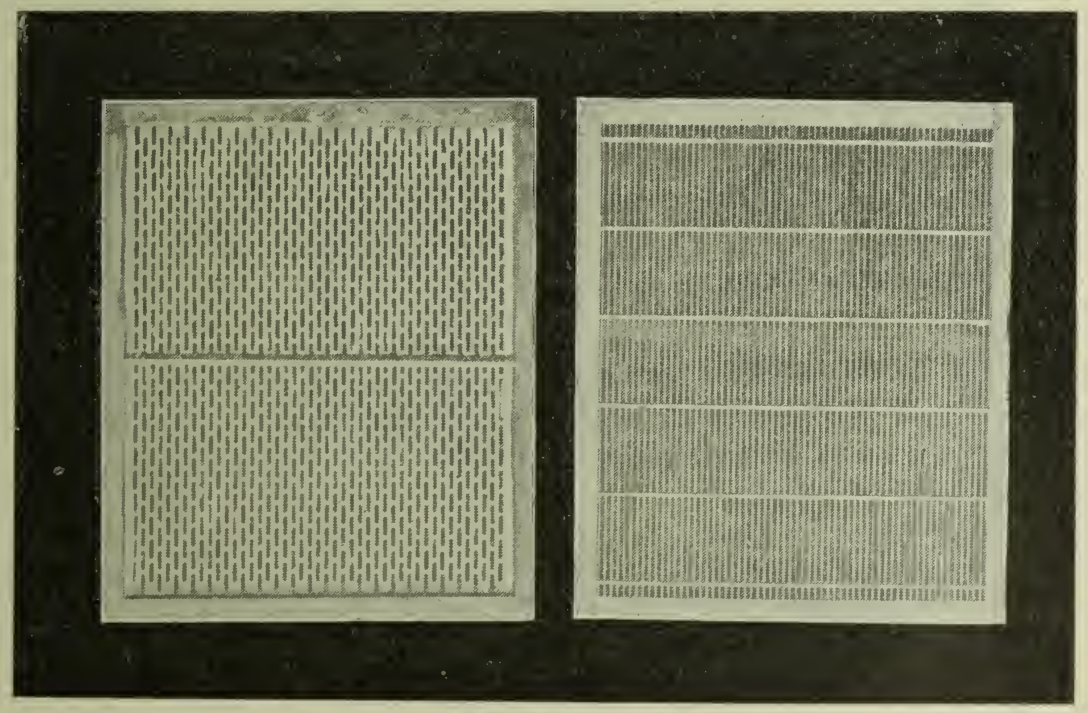

FIG. 19.-Zinc excludcr. Wire excluder.

and is not so heavy to remove when filled, but there are important advantages in having the frames in the brood chamber and the super interchangeable, and the employment of full depth supers saves much time in apiaries in regions where the honey flow is heavy. The extracting frames should be fitted with full sheets of foundation, which should be wired in, as already explained. It is also 
advisable to have one less frame in the extracting super than the brood chamber. That is a 10 -frame super should have only 9 frames, these to be evenly spaced so as to allow the bees to draw out the combs slightly beyond the edges of the frames. This makes the uncapping much easier.

To prevent the queen from entering the supers and laying eggs therein, a queen excluder is placed between the brood chamber and the supers. The queen excluder contains numerous holes about $165 / 1000$ of an inch wide which permit the passage of the workers, but are too small to allow a well-developed queen or drones to go through. The queen excluder may be made of wire or perforated zinc; the wire excluders, however, allow freer passage for the bees. In the hive there should be a clear bee space of a quarter of an inch on both sides of the queen excluder. This is obtained by having the metal excluder set in a frame of wood of the necessary thickness.

The queen excluder should be used in the production of extracted honey but it may be advisable, especially where the smaller hives are used, to allow the queen the use of the first super as part of the brood nest.

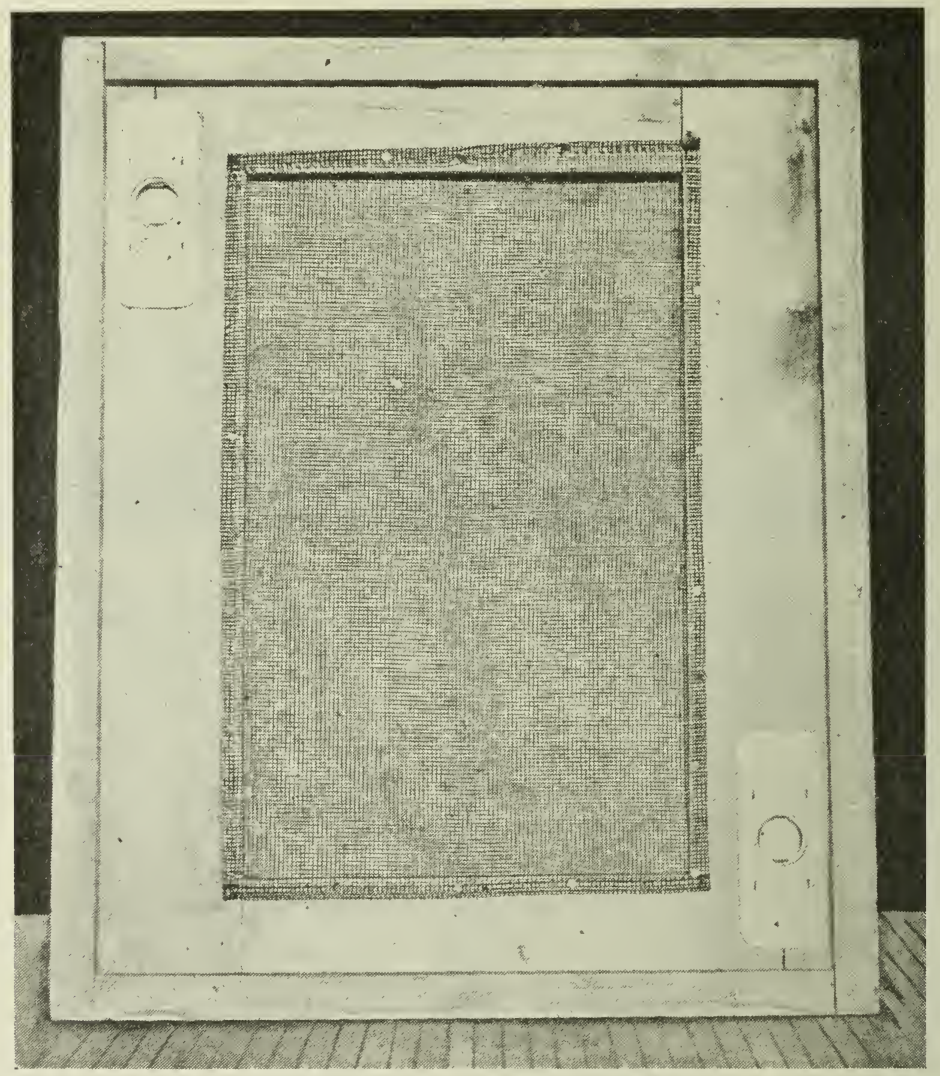

Fig. 20.-Wood-wire escape board.

The super should be placed on the hive as soon as the bees occupy the space between the outer combs and the wall of the hive, provided honey is being gathered. When the super is filling rapidly with honey and is about onethird full it should be raised and a second one placed beneath it. This will keep the bees occupied and help to discourage swarming. In removing the supers from the hive, which should not be done until the honey is all or nearly all capped over with wax, a super clearer such as is employed for the removal of comb-honey is used, or the bees may be shaken or brushed off the comb. 
The honey may be extracted as soon as the supers are removed from the hive, because it is easier to extract it when the combs are warm than when the honey has grown cold. Before the honey can be extracted it is necessary to uncap the comb on both sides; this is done by means of a sharp uncapping knife which has been heated in hot water or by a steam-heated knife.

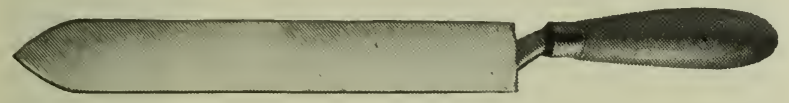

FIG. 21.-Uncapping Knife.

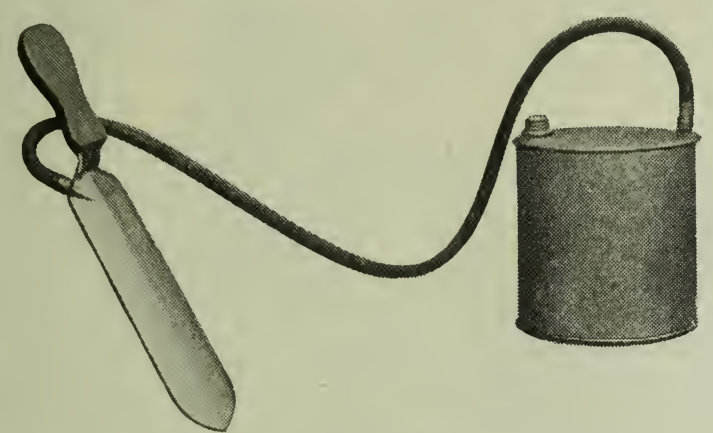

Fig. 22.-Steam heated uncapping knife with tank.

The uncapping should be done over some kind of a receptacle into which the cappings will fall. After the comb is uncapped it is placed in one of the cages of the extractor and the other cages are similarly filled. By turning the handle of the extractor the honey in the outer side of the combs is thrown out by centrifugal force. When the honey from one side has been thus removed the combs are reversed and the other side is emptied in a similar way. When honey is being extracted from new combs it is advisable to extract only part of the honey from the first side and then reverse the combs and empty the other side and then finishing the first side, otherwise the combs may be broken by the weight of honey on the inner side. In the best extractors the combs are reversed automatically. Larger extractors taking eight frames and driven by gasoline engines or electric motors may be profitably used in large apiaries. It is convenient to use a honey pump when employing a power outfit.

To expedite the work of uncapping, a pair of knives should be employed, the one not in use being kept in hot water; or a hollow knife heated by steam supplied through a rubber tube from a small boiler may be used.

It is sometimes advisable to keep the honey from different successive sources separate as far as possible, especially to prevent the main crop of light coloured and mild flavoured honey from becoming degraded by the admixture of darker coloured or stronger flavoured honey. In some parts of the country just before the main honey flow from clover comes on, small quantities of a disagreeably flavoured dark honey may be stored. This should be removed promptly. After the clover honey flow there will often be a crop, varying in colour and flavour, from buckwheat, golden rod, aster and other fall flowers.

The honey should be freed from particles of wax, etc., by straining through cheese cloth, or by allowing it to stand for a few days in a deep gravitation tank, in which the wax rises to the surface. The honey is drawn through a honey gate or tap fixed in the bottom of the tank.

Should any large amount of honey be extracted from uncapped cells, it will need to be ripened, that is, to have the excess of water evaporated out in a warm room before it is run into the containers. 


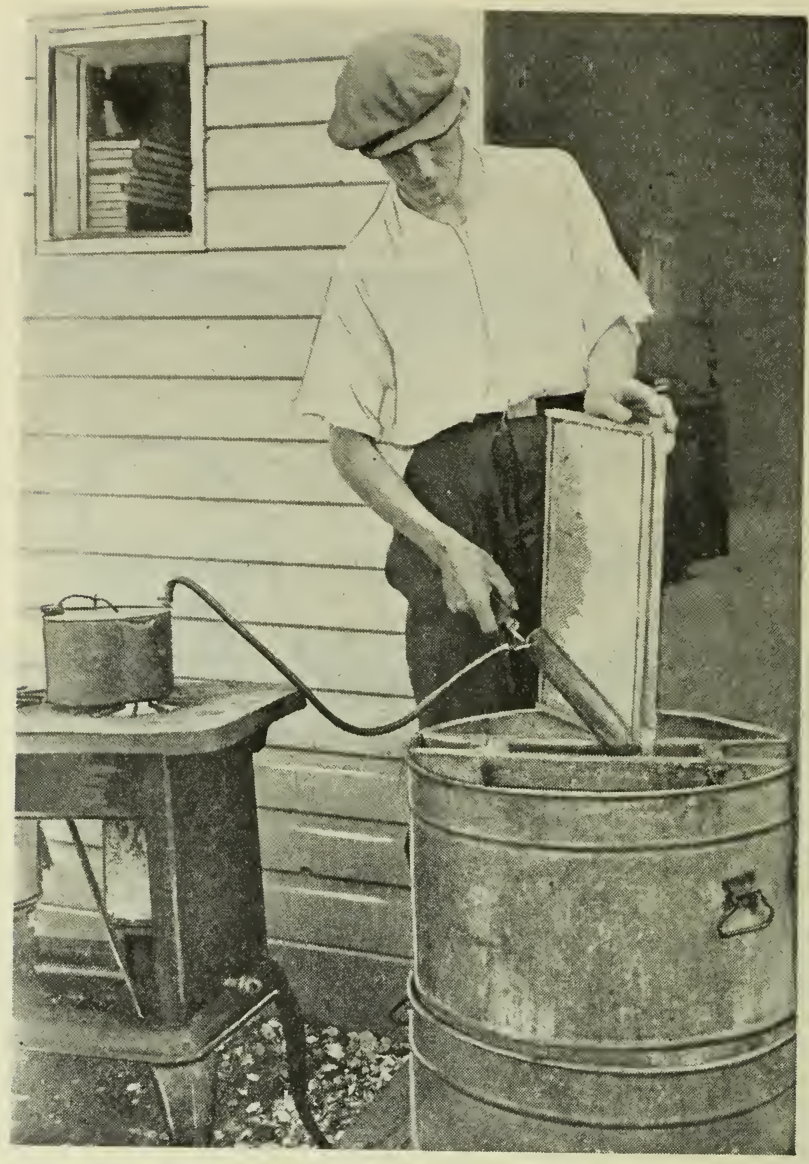

FIG. 23.-Uncapning comb of honey.

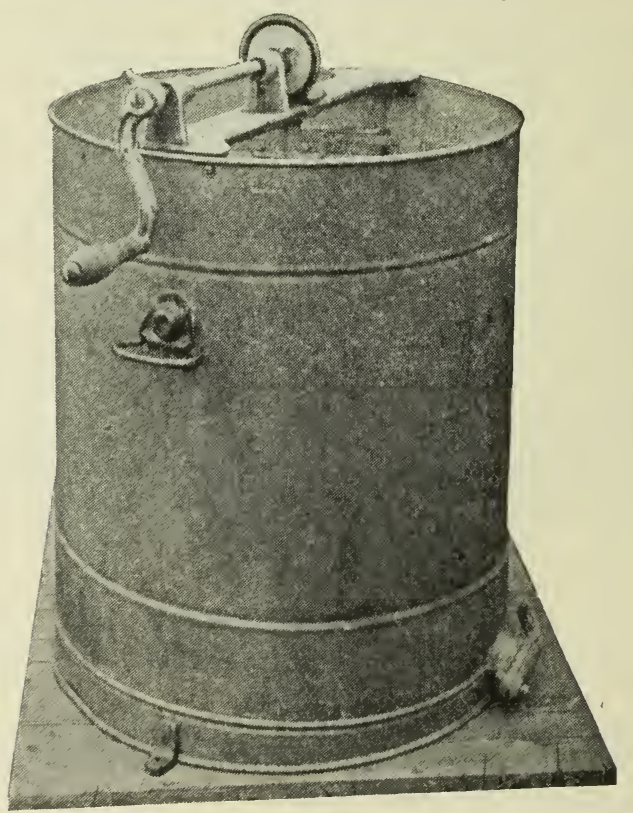

FIG. 24.-Honey extractor. 
At the end of the season the extracting combs may be returned to the bees to be cleaned prior to their being put away for the winter. A large supply of empty combs is a valuable asset.

Most kinds of honey granulate quickly after extracting. The honey should, therefore, be run into the containers as soon as it has been strained and is ripe. Stored in a dry place, honey will keep good for months and even years, but it will absorb moisture from moist air, and is then liable to ferment and decompose.

In view of the fact that nearly all Canadian honey is good enough for table use, for which purpose it realizes the highest price, the kind of container that is most likely to be in demand by consumers must be studied and selected. A convenient and economical package for distribution either through stores or direct to the consumer is the tin pail with lever lid and provided with a stout wire handle, the usual sizes hold 10 pounds, 5 pounds and $2 \frac{1}{2}$ pounds of honey.

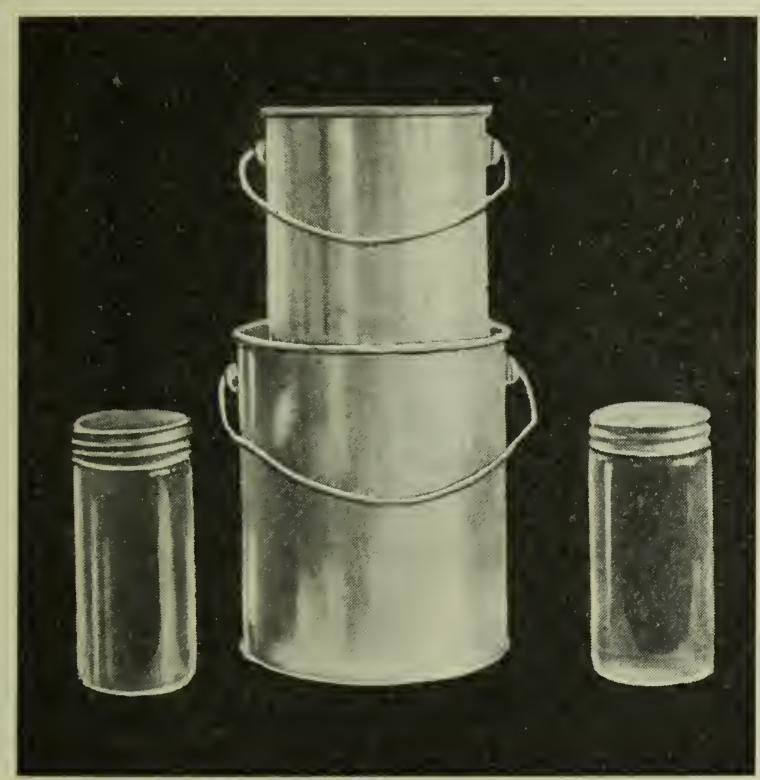

Fig. 25.-Honey Containers. 1 pound glasses; 5, 10 pound pails.

For family use, or for supplying honey to grocers to be bottled, tin cans holding 30 pounds and 60 pounds may be employed. Those who buy small quantities of honey in a retail way almost always prefer it in glass, despite the higher relative cost of the package. The most popular glass jar for retail stores is the metal screw-top jar, holding about one pound. Quart sealers holding about three pounds of honey are preferred in some places, and glass jars holding only about half a pound appeal to a small class of city dwellers. Honey in glass jars sells largely on account of its appearance. It will, therefore, pay to make it as attractive looking as possible. Care should be taken to see that the jars do not leak. For this purpose, the screw-top jars are provided with a wad or cork or other material and a circular piece of paraffined paper under it. A label, specially printed for the producer, attached to each tin or jar, helps wonderfully to sell the honey and to build up a demand for it. In many places it is easy to develop a local market for honey.

Honey in glass jars sells better in the liquid condition than when granulated. To liquefy honey so that it will remain liquid for some time, it should be placed in a water bath over a stove and heated to a temperature of about 150 degrees F. The temperature of the honev must not, be allowed to go higher

62612-4 
than 160 degrees $F$., because above that point the flavour is liable to be injured and the colour darkened. For this reason honey should never be heated directly over a stove or flame. Hermetically sealing the jars while the honey is still warm helps to prevent regranulation.

\section{CCMB-HONEY}

Comb-honey is now almost entirely produced in "sections"-small boxes made of basswood, each containing from twelve to sixteen ounces of honey when filled. The common size of the section is $4 \frac{1}{4}$ inches square. The 4 by 5 section, however, is becoming very popular because of its pleasing appearance and larger surface of comb. A comb-honey super usually contains from 28 to 32 sections. To ensure the building of the combs to a uniform thickness, a

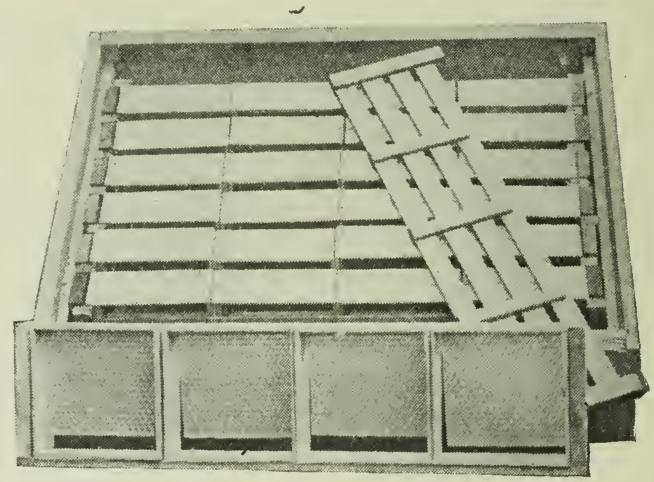

Fig. 26.-Comb-honey super.

thin sheet of wood or metal, known as a separator, should be placed between the faces of the sections. If the sections are self-spacing the separators used are plain, but if the sections are plain the separators are in the form of a fence to supply the necessary spacing.

Before the comb-honey super is placed upon the hive a sheet of comb foundation must be fitted into each section. Special thin foundation, known as thin or extra thin super foundation, is made for use in sections. Sections are usually made with a saw-cut in the top bar to receive this foundation. There are various devices for fitting the foundation into sections not having the saw-cut.

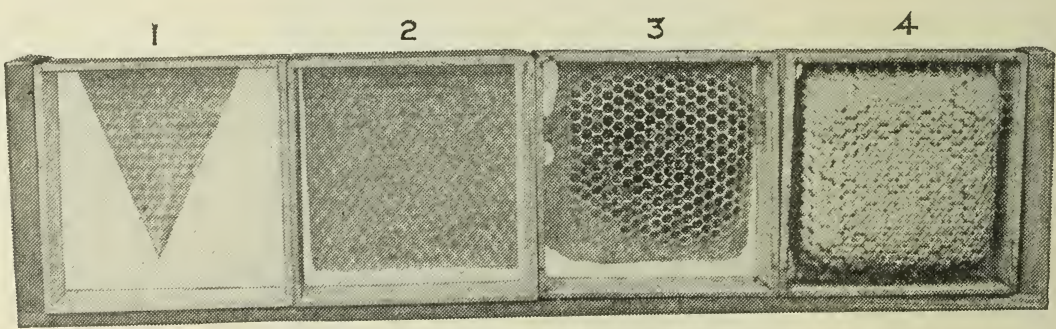

FIG. 27.-A row of sections in holder.

1. Section fitted with starter of thin super foundation.

2. Section fitted with full sheet of thin super foundation.

3. Partly filled section.

4. Completed section. 
The queen is less inclined to enter the comb-honey super than the extracting super, especially if the form of super in which each row of sections is placed in a section holder is used, consequently it is usually unnecessary to use a queen excluder for comb-honey production.

Early in the honey flow, if nectar is coming in quickly, a new super may be given to a strong colony as soon as work in the first super is well begun. As soon as all the sections in the super are capped over it should be removed from the hive. Before removal, the super should be emptied of bees by means of a super-clearer placed beneath it. The super-clearer consists of a board with a hole in the centre or at two corners into which is fitted a device known as a bee-escape through which the bees can pass only one way. The superclearer having a hole in each corner is usually fitted with a double thickness of wire cloth in the centre which acts as a ventilator. (See fig 20). In warm weather the super-clearer will empty a super of bees within twenty-four hours.

To ensure the best returns from comb-honey production, not only is it necessary to have a rapid flow of honey but the field force should be large and the bees crowded in the super in order that the filling of the sections may proceed as rapidly as possible. Unfortunately these conditions favour the development of the swarming impulse. If the bees swarm the swarm should be hived on the old stand as explained under Swarm Control, or the swarm may be made artificially, and it should be supplied with full sheets of foundation in the brood chamber in order that it may concentrate on the work in the super. One empty comb, however, should be given to receive the pollen. By treating swarms in this way almost as large a crop of honey may be obtained as when swarming does not take place.

The volume and duration of the honey flow must be well estimated in order that sufficient, but not too many, sections may be given, so that the bees may finish as large a proportion of them as possible, an unfinished section being of value only for extracting and for use in the following year as a bait comb to entice the bees into the super which with its many little compartments, is less readily taken possession of by the bees than an extracting super.

Since comb-honey is a fancy article it usually pays to produce it in perfection. A good section of honey should have all the cells filled and capped over, excepting perhaps a few in the row next the wood, and the wood should he scraped clean and free from propolis.

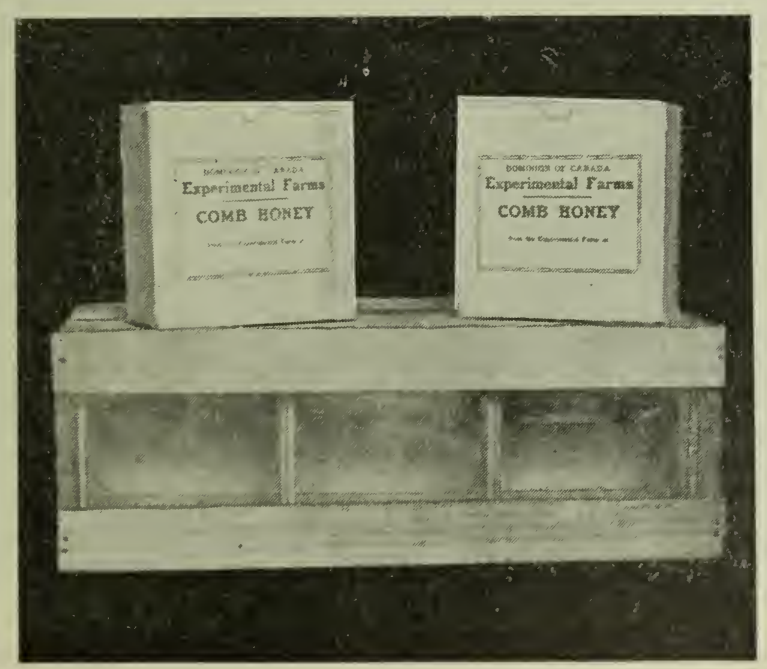

FIG. 28.--Shipping case and cartons for section honey. 
Comb-honey should be kept' in a dry warm place from the time it is removed from the hive until it is sold, and it calls for a package protecting it from dust and insects. For selling it in quantity a glass fronted shipping case containing 12 or 24 sections is perhaps the most satisfactory package. Single sections may be enclosed in cardboard cartons.

\section{List of Principal Honey-Producing Plants with Their Approximate SEASONS OF Yield}

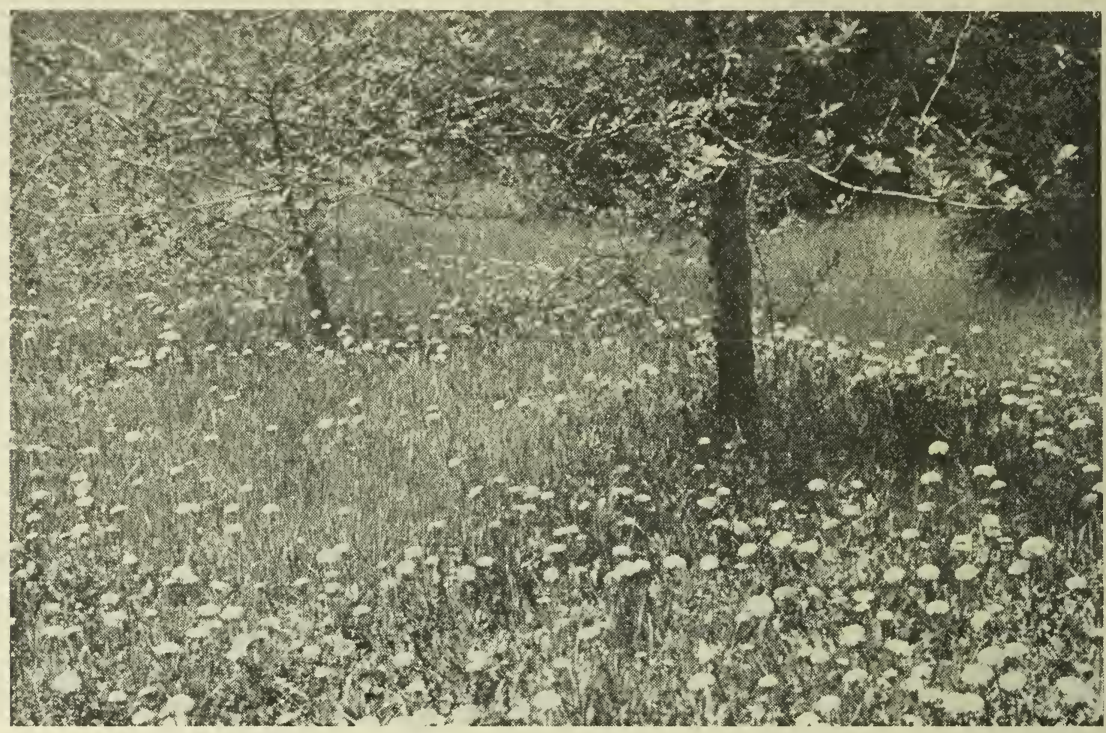

Fig. 29.-Dandelion.

FOR BROOD-REARING

Willows.-Mid-April to mid-May; on the Pacific coast, March.

Maples, various species.-The Pacific coast species are especially valuable, but the Manitoba maple and some of the eastern species are unimportant. April and May.

Dandelion.-Will often produce surplus honey in a favourable season. May and early June. On the Pacific coast, April.

Apple, Plum, Cherry and Peach Orchards.-In places where apples are grown extensively surplus honey is obtained from apple bloom in favourable seasons. May and early June. On the Pacific coast, April.

Bearberry (Arctostaphylos uva-ursi), known locally by the Indian name "Kinikinic," Kootenays, B.C., and other places. The abundant nectar in this plant is not entirely within reach of the bees, May.

Blueberries.-Eastern Canada, May. 

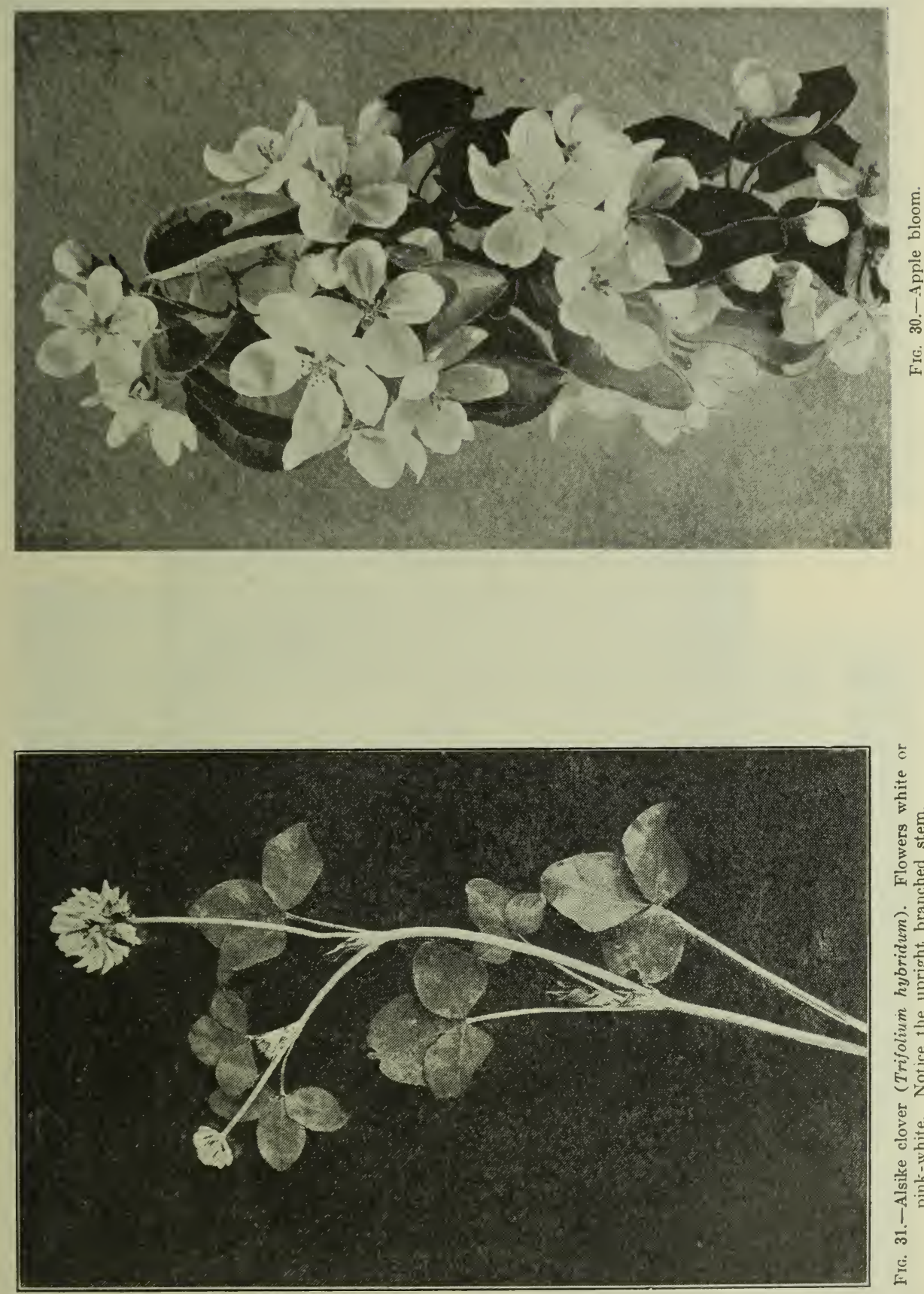

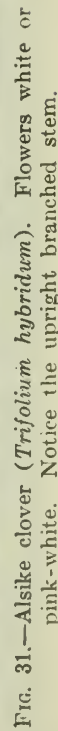


FOR SURPLUS HONEY PRODUCTION

Raspberry, principally in forest clearings. June.

Alsike Clover (Trifolium hybridum) and White Dutch Clover (Trifolium repens).-Wild and cultivated throughout the farming regions of Canada except on the drier parts of the prairies. These are the most important honey

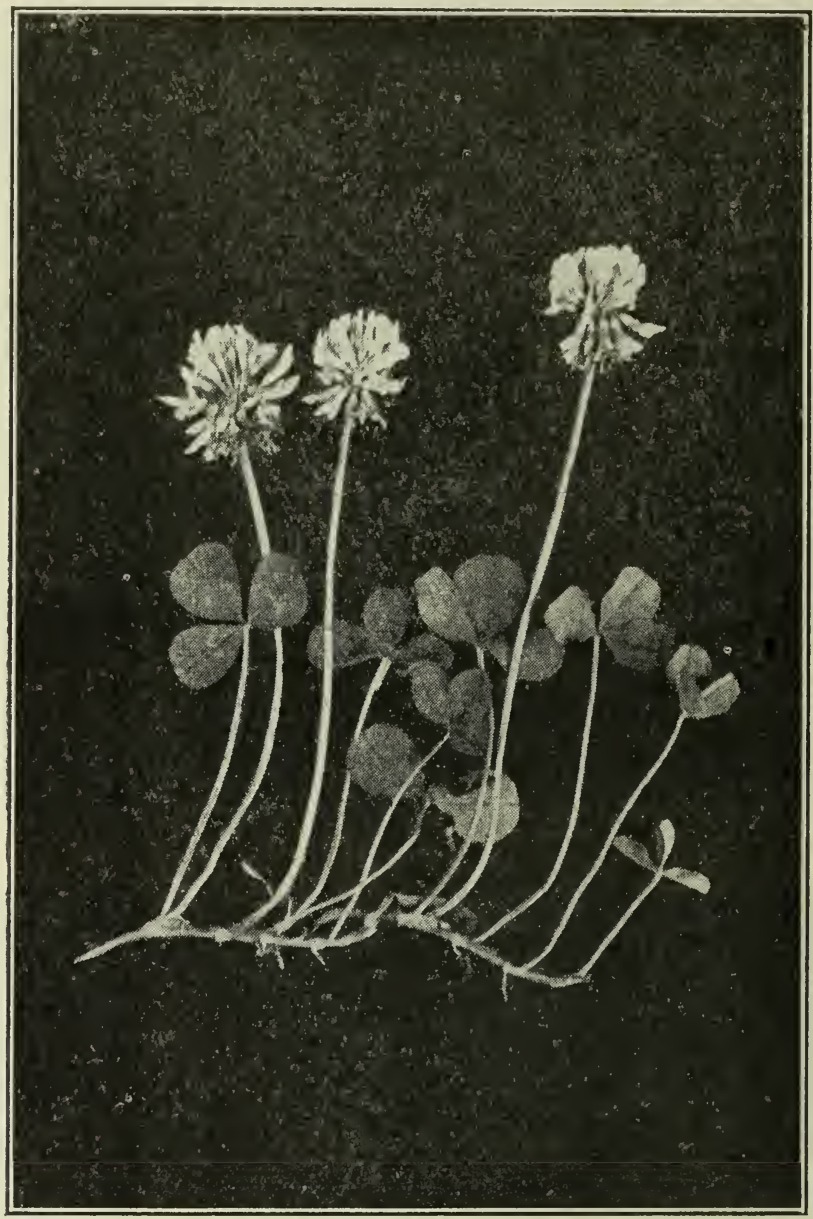

FIG. 32.-White Dutch Clover (Trifolium repens) Flowers white. Notice the creeping stem.

plants of Canada, but under excessively dry or cool conditions they fail to yield sooner than many other plants. In some years the amount of clover is much reduced by the plants being killed by repeated severe freezing and thawing when unprotected by snow in winter and spring. In the districts of Ontario where alsike clover is grown for seed, beekeeping is an important industry. Colour of honey light, flavour excellent. These clovers do not usually commence to yield nectar in Ontario and Quebec until they have been in bloom for one or two weeks, and on the Pacific coast for three or four weeks. Duration of honey flow, two to five weeks. Mid June to end of July.

Alfalfa.-Southern Alberta and British Columbia dry belt. Of no value for surplus honey production in the east. End of June to August. 


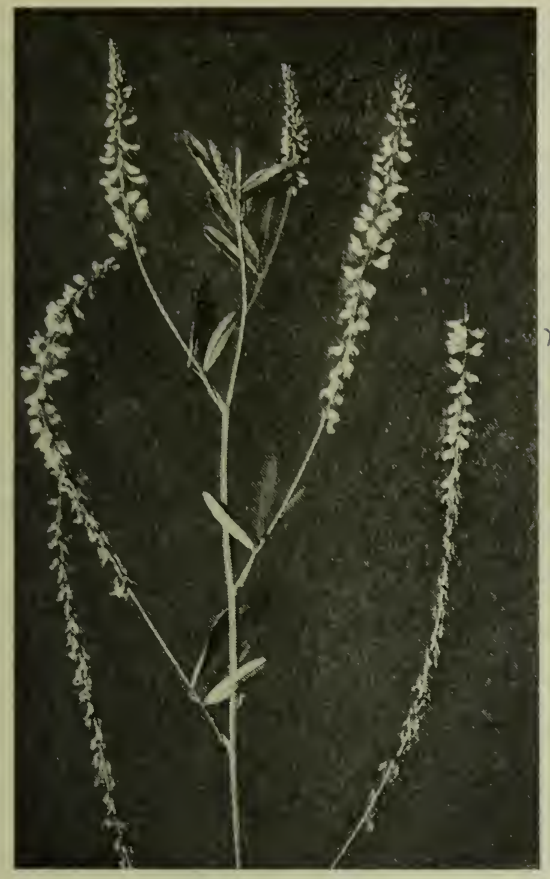

Fig. 33.-Sweet Clover.

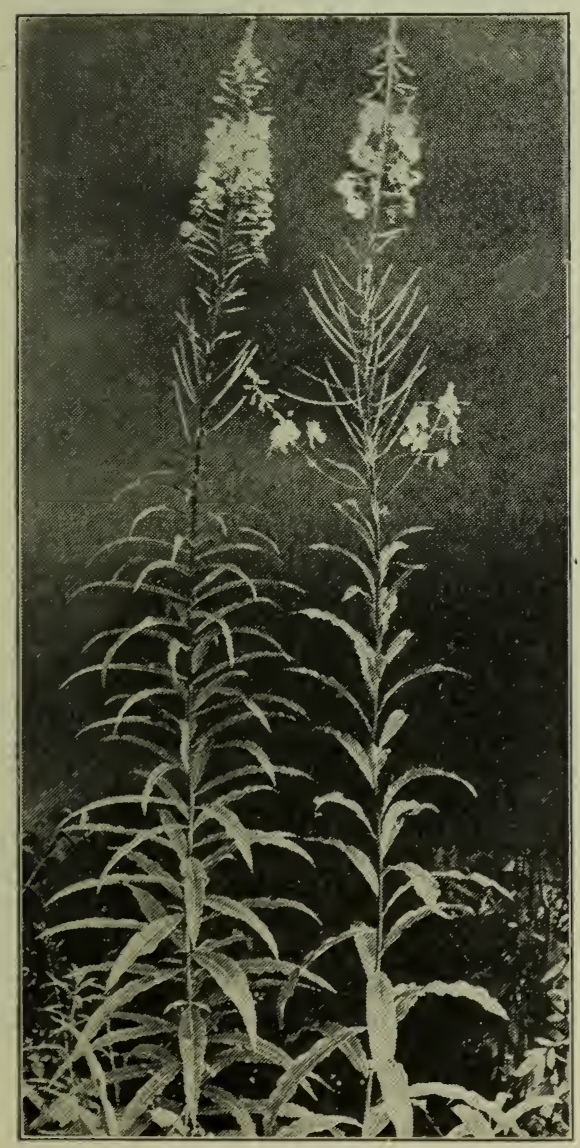

FiG. 35.-Fireweed.

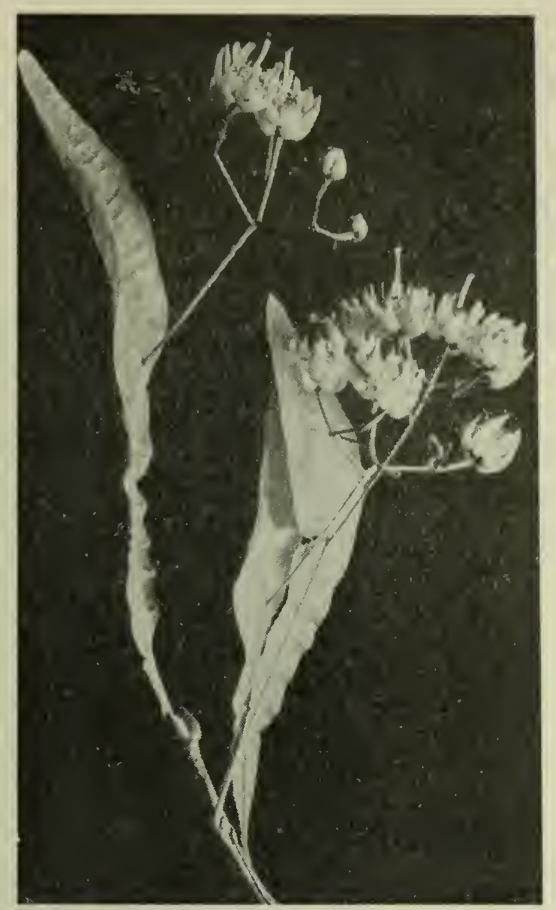

Fig. 34.-Basswood

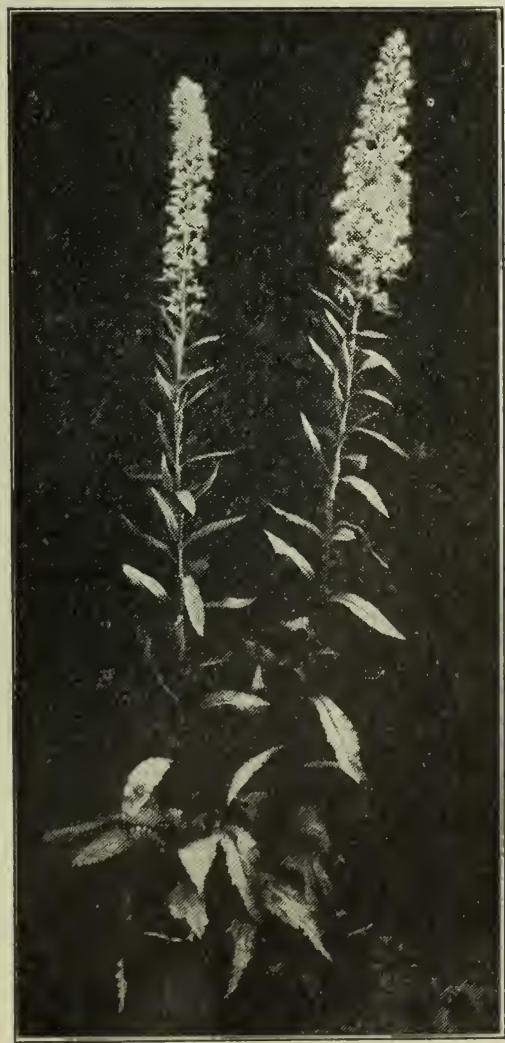

Fia. 36.-Golden Rod. 
Sainfoin.-May become a valuable source of honey in the Upper Columbia River Valley, B.C., and in other places where it can be cultivated successfully. End of June to August.

Wild flowers of different kinds found on the prairies. Collectively these are important. Among them may be mentioned Wild Bergamot (Monarda fistulosa) and various mint June to September.

Basswood (Tilia americana).-Ontario and Quebec. Less plentiful than formerly. Yield very uncertain, in some years heavy. Colour of honey light, flavour pronounced. July.

Snowberry (Symphoricarpos).-British Columbia. July.

Wild Radish (Raphanus raphanistrum).-Maritime Provinces. Abundant in the Annapolis Valley, N.S., where it yields a considerable amount of honey. July.

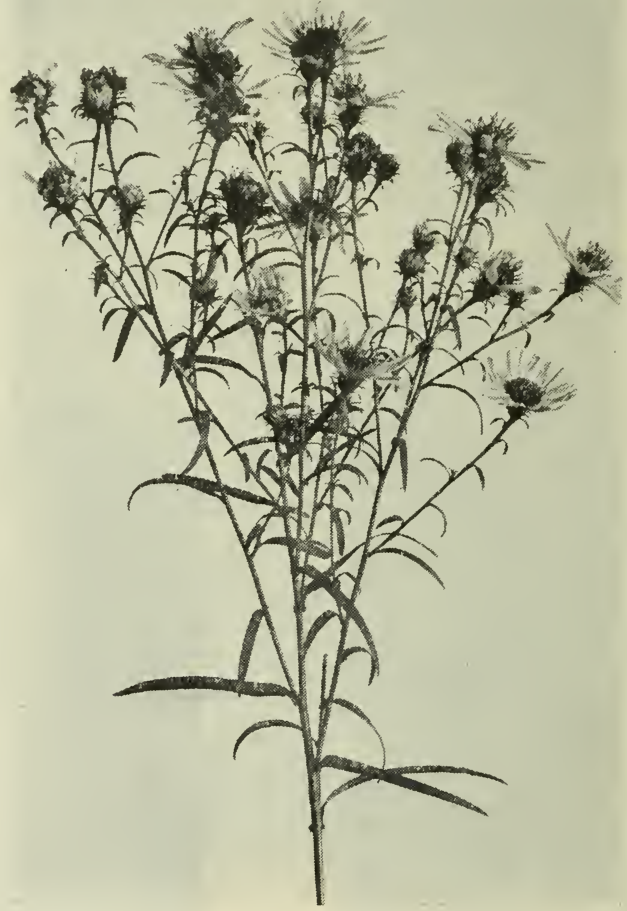

Fig. 37.-Aster.

Sweet Clover (Melilotus) whice and yellow.--Very attractive to bees and of growing importance because the plant is spreading. The honey is inferior to clover honey. July and August.

Great Willow-herb or Fireweed (Epilobium angustifolium).-A tall plant three to seven feet high with long racemes of showy red-purple flowers; a valuable source of honey in forest clearings and places recently devastated by fire. Colour of honey almost water white; flavour mild. In British Columbia the colour is darker, but this may be due to the admixture of other honeys. Duration of honey flow, seven to eight weeks, not stopped by drought. July and August. 


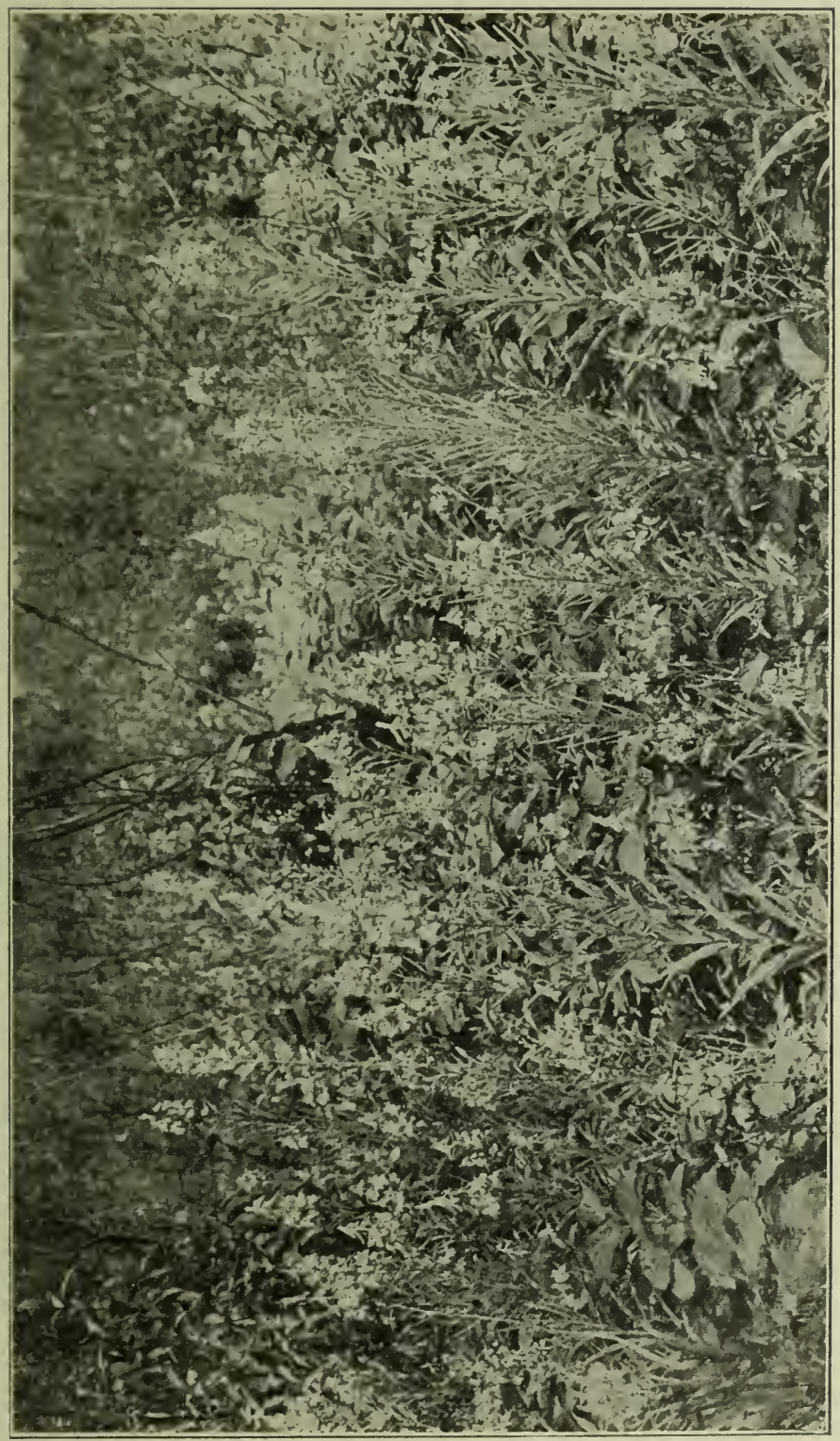


Buckwheat (Fagopyrum esculentum).-Important in the Upper St. Lawrence Valley, southern Quebec and old Ontario. Colour of honey is dark and flavour strong. August.

Golden Rod (Solidago); Aster.-Of the many species of golden rod and aster some are good honey producers under suitable conditions, especially in the east; others, including some of the common early flowering species, are of little value. The honey varies in colour and quality. That gathered in the Gatineau Valley, north of Ottawa, in September is white. Solidago puberlua and Solidago squarrosa have yielded about 40 pounds of lightcoloured honey per colony on a sandy plain forty miles north of Ottawa. August and September.

It should be noted that a large crop of honey depends not only upon the abundance of flowers but upon favourable weather-in the case of most plants, rain, followed by warm sunny weather during the honey flow-and also upon the climate, soil and other conditions best suited for each variety of plant. In some places and seasons the less important honey plants, of which there are many, yield surplus honey which frequently influences the colour and flavour of the honey gathered from the main sources. Among these may be mentioned:-

Milkweed (Asclepias)

Dogbane (Apocynum) especially in the British Columbia dry belt

Boneset (Eupatorium perfoliatum) (Ontario)

Viper's Bugloss (Echium vulgare) (Ontario)

Wild Mustard (Brassica arvensis)

Canada thistle

Buckthorn
Sumach (Ontario)

Button-bush (Southern Ontario)

Blackberry

Smartweed

Catnip

Motherwort

Hound's Tongue (Cynoglossum) (Ontario)

Sheep laurel (Kalmia)

Blue Vervain

Some of these produce considerable quantities of honey locally. It does not pay to grow crops specially for bees, but alsike, white clover, alfalfa, sainfoin, sweet clover, and buckwheat are valuable farm crops and excellent for bees in the areas that have been indicated for each. In the regions favourable for alsike, white clover and sweet clover, where these are absent or scarce, the seed may profitably be scattered about.

In localities where alsike or white clover grows abundantly it is not wise to introduce sweet clover as the bees will work on it busily when it is not secreting much nectar, often neglecting the more valuable clovers, which produce a honey of superior quality. Red clover occasionally produces surplus honey when the flower tubes have been sufficiently shortened by drought for the bees to reach the nectar.

Bees are much attracted by the flowers of certain ornamental shrubs such as the Siberian Pea Tree (Caragana) and garden flowers such as mignonette, but these are seldom abundant enough to be of any practical value. Caragana hedges, however, should be planted around homesteads where bees are kept in the prairie provinces, as they provide not only food in spring, but also shelter from the wind.

\section{SWARMING}

Swarming is the bees' natural method of increase and is likely to occur in the majority of the colonies in spring and early summer when the hives are populous and honey is being collected, and also sporadically at any time in the summer during a honey flow. 
A few days before swarming the bees commence to rear queens, and the swarm containing the old queen usually issues about the time when the earliest queen cells are capped.

The swarm generally settles upon the branch of a trce near the apiary. In securing the swarm, advantage should be taken of the bees' fondness for running into a cavity.

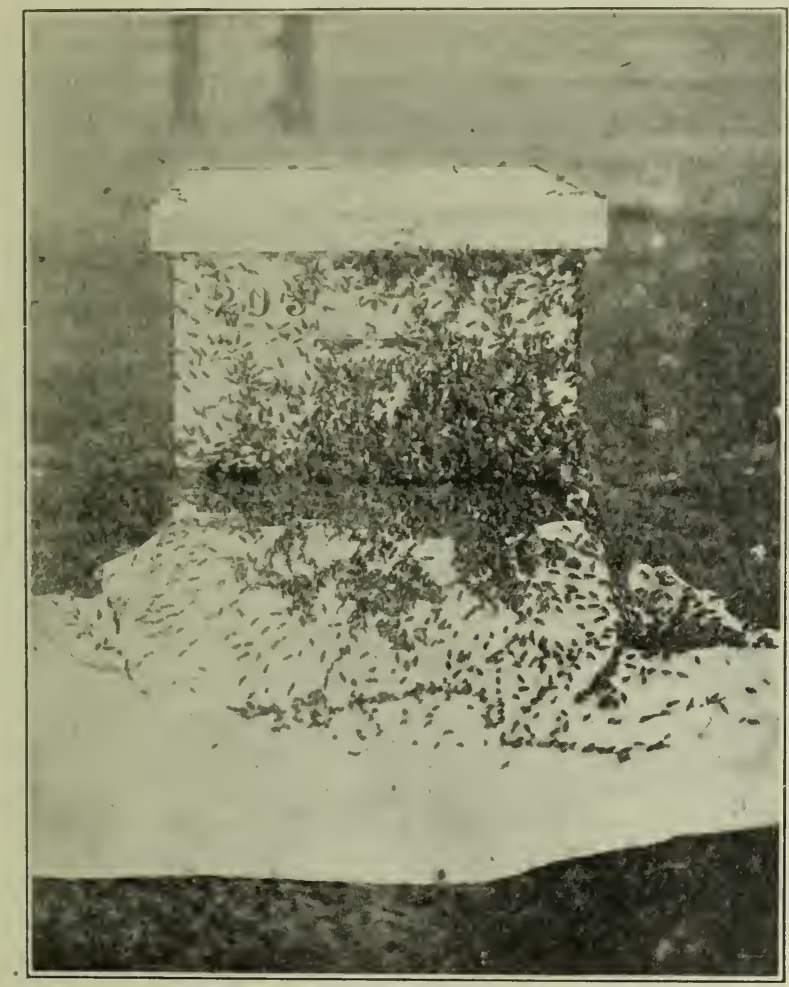

FIG. 39.-Swarm Entering Hive.

A new hive containing drawn comb or frames fitted with foundation should be prepared to receive the swarm. This hive may be brought close to the clustering swarm. Some of the bees should be shaken into the hive; the remainder should then be shaken into a box and immediately dumped on to a sheet spread before the entrance of the hive. If it is not convenient to bring the new hive to the swarm the bees should be shaken first into the box which should be then turned upside down on the ground nearby and propped up with a stick or stone to collect the stragglers and in the evening the bees are shaken out in front of the new hive. A comb containing brood may be placed in the new hive to prevent the swarm from absconding.

A swarm will need feeding on the third day after hiving if bad weather has prevented the bees from collecting honey. About eight days after the issue of the first swarm the first of the young queens will emerge and then a second swarm may go off with some of these queens. A third swarm may come out and go off a few days later. Second and third swarms are usually too weak to be of much value, and should be prevented by destroying all the queen cells but one in the parent colony within seven days after the first swarm comes off; or, destroying all the queen cells and introducing a new queen. 
It should be noted that the earliest sign of definite preparation for swarming is the presence of eggs in queen cells, the first of which are usually laid about eight days before the swarm is due to leave. Queens are also reared when the colony is preparing to supersede its failing queen, but in this case there is much less than the normal amount of brood. A colony that is superseding its queen is not unlikely to swarm if it is strong, though it usually delays to do so until the first of the young queens emerge.

Since queens are sometimes lost on their mating flight it is advisable to make an examination of colonies that have thrown swarms about twelve days after the young queen has emerged. If eggs are present the queen is probably fertilized. If there are no eggs, a frame of brood in all stages should be given; from this the bees will raise a queen if their queen is lost, but it is better to give a laying queen.

\section{SWARM CONTROL}

The time when success in beekeeping was measured by the number of swarms hived has passed, and nowadays the progressive beekeeper endeavours to prevent swarming. One of the troubles encountered in permitting bees to swarm is the frequent difficulty of capturing the swarm which may collect in an inaccessible situation, or even fly across the country. Then there is the time spent in watching for the bees to swarm and in hiving swarms. But by far the most serious disadvantage of swarming is the fact that the swarm and the parent colony produce less honey than the same bees would have had they remained in one colony. Indeed, instances are not rare in which unrestricted swarming has entirely prevented the production of surplus honey in an apiary. It is not too much to say that the control of swarming is probably the most important and difficult problem that most beekeepers in Canada have to face. Careful study of the bees' behaviour is needed to successfully cope with it. Fortunately for the beekeeper, several days' warning of the probability of the issuing of a swarm is given by the appearance of eggs in queen cells.

Colonies vary much in their propensity to swarm, even under the same conditions and in the same apiary. By replacing the queens of colonies that swarm with queens that are the progeny of queens whose colonies have not swarmed the beekeeper may hope to reduce the percentage of colonies that swarm. Another point that should be noted is that colonies containing queens under a year old are less inclined to swarm than those in which the queen is older.

The most successful measures of swarm control are, however, by manipulation. Preparations for swarming may often be prevented by giving an abundance of ventilation during the honey flow, by raising the front of the hive from the floor boards by means of small blocks; by giving the bees plenty of room for brood production and storage of honey; by raising a few frames of brood from the brood chamber at each examination or by destroying all queen cells that contain eggs or larvæ. Where hives smaller than the 10 -frame Jumbo are used it is a good plan to allow the queen a second chamber for brood production. For hives smaller than the 10-frame Langstroth a deep chamber should be used. For the 10-frame size a shallow super is sufficient. In using the double brood chamber the first preparations for swarming can usually be detected by merely tipping the upper chamber and finding queen cells along the lower edges of the upper combs. (See fig. 40). For colonies that have made advanced preparations for swarming either of the following methods can be used (1) As soon as larvæ are found in queen cells remove the old queen and destroy all queen cells; ten days later again destroy all queen cells and introduce a young laying queen. (2) At the time larvæ are found in queen cells remove all frames of brood from the brood chamber and replace them with drawn combs leaving the queen on these combs. 
The brood can either be used for making nuclei or placing it over a queen excluder on top of the colony.

Some colonies, however, especially those in which the bees are crowded for the production of comb-honey, may persist in building queen cells. Colonies that behave in this way not only entail a great deal of labour on the part of the beekeeper in searching for and destroying the cells (which is useless should

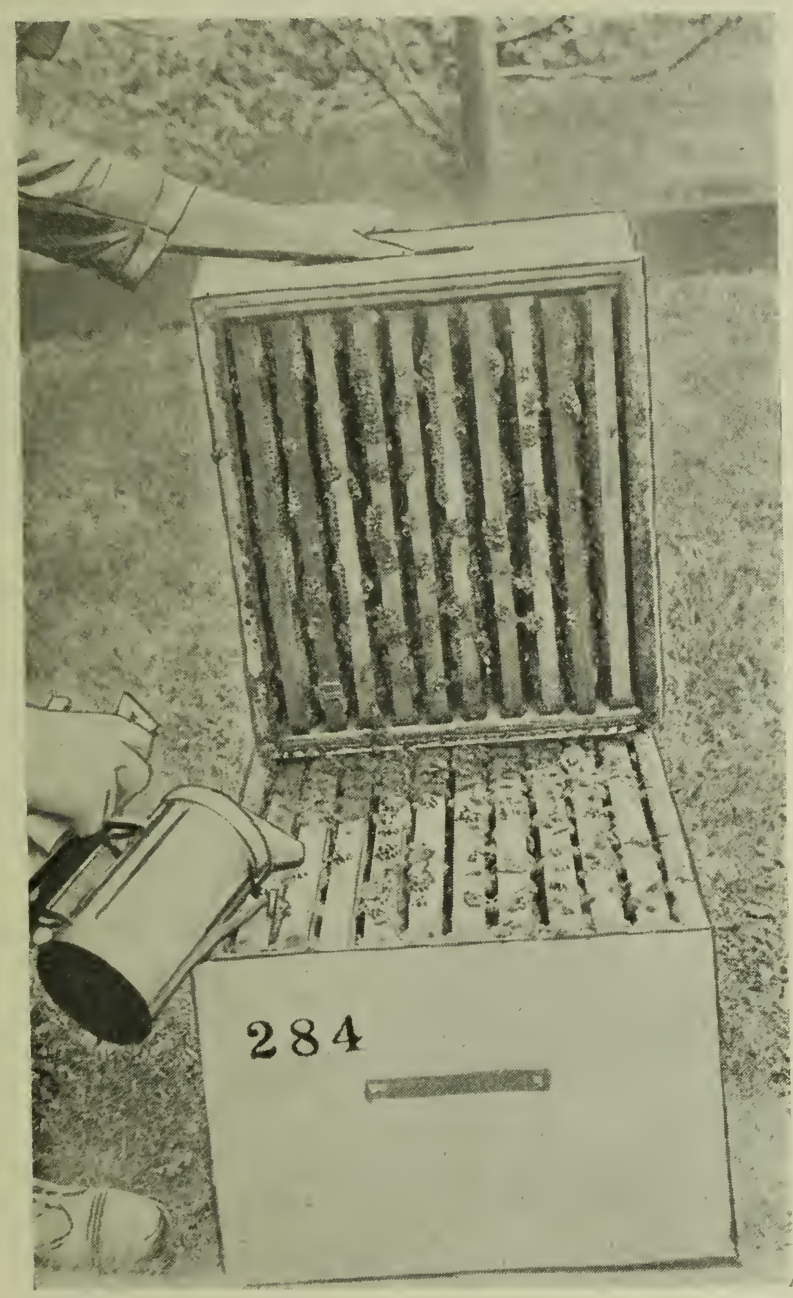

FIG. 40.-Detecting preparations for swarming by tipping super.

one cell be missed), but they become lazy. The best way to deal with such colonies is to permit them to swarm or to make artificial swarms from them, but, at the same time, to compel nearly all the field bees, by manipulation that is about to be described, to join the swarm so that the swarm may continue the work of honey storing and the parent colony may be so depleted of bees that it will not swarm again. 
In order to prevent the possibility of the swarm flying away it is a very good plan to clip the queen's wings; this should be done at the second examination of the colonies in the early spring before the bees become numerous enough to make it difficult to find the queen. Clipping the wings also affords a ready means of marking the queen. $\mathrm{W}^{\mathrm{t}}$ hen clipping is practised and swarming allowed, the grass around and to some distance in front of the hives should be kept short during the swarming season, and someone should be present in the apiary to attend to the swarm when it emerges, and find and pick up the queen. While the swarm is still in the air the queen is placed in a cage, and the hive is turned around and placed at right angles to its former stand. Without delay a new hive containing frames fitted with drawn combs or foundation is placed on the old stand and the queen in her cage is placed at the entrance of this hive so that the swarm upon returning finds her and enters the new hive. The queen may then be set free among the bees. The supers are removed from the old hive and given to the swarm over a queen excluder. The old hive is then gradually turned so that at the end of three days its entrance is again facing the same direction as that containing the swarm. On the seventh day when the bees are working freely the parent colony is then removed to another part of the apiary, the field bees will then enter the new hive and thus strengthen the swarm and the parent colony is too weak to throw after swarms.

In regions where the nights are warm the swarm may be made artificially from a colony that has larvæ in queen cells by shaking the bees off their combs into a new hive on the old stand. Sufficient bees should be left with the brood to feed it and prevent its getting chilled.

Occasionally colonies are found that will swarm with only eggs or young larvæ in queen cells or even before any queen cells have been built, but these cases are rare.

Swarming is more frequent when the honey flow is light or irregular than when it is abundant and steady.

\section{DIVIDING COLONIES FOR INCREASE}

To increase the number of colonies without natural swarming dividing may be practised. If a crop of honey is desired colonies should not be divided before the honey flow. Heavy increase can only be made at the expense of honey production. As a rule no colony should be divided until the bees nearly or quite fill the brood chamber. The part that is removed to a new stand should consist largely of young bees, because these are not so likely to return to the parent hive as the field bees. All or nearly all its brood should be capped as eggs and young larvæ are likely to be destroyed in large numbers. The part that does not contain the queen should be supplied with a fertile queen or a ripe cell, that is, one from which the queen is about to emerge. With a normal colony it is hardly possible to fulfil all these conditions in one operation.

One of the best methods of dividing a colony into two and not affecting the honey crop to any great extent is the following: During the first week of the clover honey flow remove the queen and one frame of emerging brood with adhering bees from the strongest colonies and place them in a new hive on a new stand, fill up the hive with one comb of honey and eight empty combs. This nucleus will build up into a strong colony by the fall when the queen can be replaced if necessary. Nine or ten days after removing the queen either destroy all the queen cells except one in the parent colony or better still destroy all the cells and introduce a laying queen. 
If a larger increase is desired either of the following methods can be used:-

(1) The queen is found and placed with one comb of brood containing no queen cells in a new hive which is then filled up with frames of empty comb or foundation. This hive is then put on the old stand, a queen excluder is placed over it and on top of this is put the old hive containing the remainder of the brood. Nine or ten days later the old hive, which now contains young bees and capped brood but no eggs or young larvæ is removed and divided into three parts, each division is placed on a new stand and a fertile queen or ripe queen cell is introduced to it, any queen cells that may have been built in the combs above the queen excluder having been cut out on the fifth day after the first operation, and again at the second operation on the ninth or tenth day. If no queen or queen cell can be introduced the new colony may be allowed to requeen itself from the queen cells that have been built.

(2) As soon as the colony is strong enough to spare brood, two or three frames of emerging brood with adhering bees are taken and placed in a new hive on a new stand, taking care that the queen is not on these combs. Fill up both hives with drawn combs. A young laying queen is then given to this new hive. About two or three weeks later more brood can be taken and another colony started giving it also a laying queen. The first nucleus made can be drawn upon for brood later in the season.

It is not advisable to make divisions after the middle of July because the new colonies will hardly have time to build up to full strength before winter, nor after the honey flow has ceased because of the risk of robbing.

\section{POLLEN}

The yellow, white or red pellets that the bees carry home from the fields on their hind lege are not wax, but pollen. This material is packed into the cells around the brood nest and is used largely in preparing brood food. A shortage of pollen that occurs in some places in early spring is rare in this country, the willows especially supplying an abundance of this material.

\section{THE PRODUCTION OF WAX}

Beeswax being worth more than twice as much per pound as honey, all the wax that is produced in the apiary should be saved. In an apiary worked for extracted honey the wax will come principally from cappings. In every apiary old combs that have been rejected for some fault, pieces of adventitious comb, pieces of drawn comb that have been cut out of worker combs, trimmings of foundations, etc., accumulate. A special box should be kept in the honey house to receive these scraps of wax. The best way to deal with cappings and pieces of clean new comb is to place them in a solar wax extractor, consisting of a glass covered box containing a sheet metal tray, which will melt the wax by the heat of the sun during the warmer months of the year; but combs that contain much pollen or have been used for rearing brood so often that they have become darkcoloured cannot be rendered profitably in the solar extractor and must be melted over a fire in boiling water or by steam. A certain amount of wax may be extracted from such combs by rendering them in a wax extractor made on the principle of a potato steamer, but to get nearly all the wax out of them it is necessary to subject the molten mass to pressure. Two excellent wax presses, known as the "Sibbald" and the "Hershiser" can be obtained from any manufacturer of bee supplies and either of these will soon pay for itself in an apiary 
of thirty or more colonies. If the combs are rendered and pressed out of doors, the work should be done during the honey flow so that robbing will not take place. Bee supply dealers will readily take beeswax in exchange for comb foundation, charging only a few cents per pound for making the foundation.

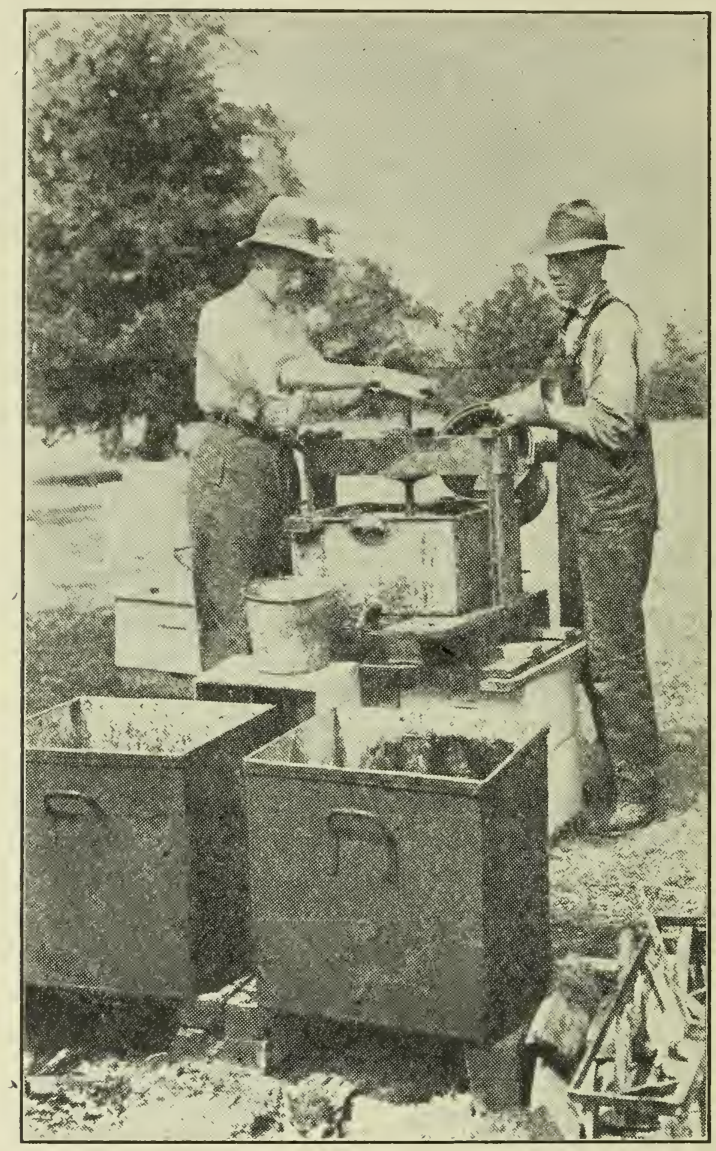

FIG. 41.-Rendering o!d combs in wax press.

Rendering wax can also be done during the winter months but should be done in a warm room.

\section{WINTERING BEES}

Bees do not become torpid in winter like other insects, but they generate heat and consume their stores. In cold weather the bees form a compact spherical cluster, the outside ring of which, according to Dr. Phillips, does not go below a temperature of 57 degrees F. Successful wintering depends principally upon the number of bees in the cluster, the youth of the bees, sufficient and wholesome stores, and protection from cold. When good protection is provided the bees do not need to produce so much heat consequently less stores are consumed and there is less drain upon the vitality of the bees.

Preparation of bees for winter, therefore, begins by seeing that each colony has a good fertile queen and enough bees to crowd the spaces between seven to ten combs, the more the better, and that these colonies consist principally of young 
bees that have done but little field work. Weak colonies must be united or brought together two in one hive with a tight-fitting division board between them. To get plenty of bees reared in August and September in regions where but little honey is gathered during these months, the queen should be one that has been reared during the summer preferably during July. Since such a queen will also usually build up her colony more rapidly and to greater strength in the spring, and will be less inclined to swarm than an old queen, the advantages of requeening colonies that have old queens are great and it will often pay to buy queens for this purpose if they have not been reared.

Each colony should have thirty to forty-five pounds of wholesome sealed stores if it is to be wintered out-of-doors, the amount depending on the intensity of the cold, and thirty to thirty-five pounds if it is to be wintered in the cellar. The weight of an ordinary 10-frame Langstroth hive made of white pine with walls seven-eighths of an inch thick, with five-eighths inch thick bottom board, combs, bees and pollen, but without cover, is, if dry, usually between 30 pounds and 35 pounds, so that in weighing hives for the winter the weight of stores present may be estimated by deducting 35 pounds from the total weight of the colony. Any deficiency in weight is made good by giving the bees full combs of honey or by feeding as rapidly as possible during the fourth week in September or (the first two weeks in October in southern Ontario), with sugar syrup made. and supplied as described under "Feeding", allowance being made for loss due to evaporation and consumption.

To avoid dysentery it is good practice to give each colony at least ten pounds of syrup. This is stored next to the cluster which occupies the empty parts of the comb from which the last brood emerged, and it is therefore consumed first, so that the accumulation of the faeces is delayed. At the Central Experimental Farm, Ottawa, where a considerable amount of honey is gathered from wild flowers in August, it has been found that colonies whose stores have been thus supplemented with about ten pounds of syrup winter better than those whose stores consist of honey only, and this has been found to be the case in many places in Canada. If honey dew or other stores that quickly produce dysentery are suspected to be present in quantity, the combs containing these stores should be removed and replaced with combs of clover or buckwheat honey, if these are not available move the central combs to the outside and fill up the hive with empty combs and give sugar syrup.

In most places in Canada the bees may be wintered successfully out-of-doors, provided adequate protection is given, but in regions where the winter is very long and cold it is advisable to winter them in a cellar. In places where there is a choice between the two methods, outdoor wintering is often preferred, especially by absentee beekeepers, for out-apiaries because the bees need no attention from the time they are prepared and packed for winter at the end of September until spring has opened. If, however, a good cellar where the best conditions of temperature, ventilation and humidity can be secured the bees can be wintered over safely with less expense than by building cases.

\section{OUTDOOR WINTERING}

Bees wintered outside should be snugly packed in cases that will allow for three or four inches of packing material between the hive and the inner wall of the case, on the bottom and all sides and eight to ten inches on top. Cases that will hold one or more hives can be used. These cases must be provided with an entrance opposite each hive and with a waterproof cover. It should also be raised about four to six inches from the ground on a frame. A good economical case is one that will take four hives as shown in fig. 42. A suitable size for the outside entrance is six inches long by one inch high. 
During the coldest months this can be reduced to three-eighths of an inch long by one inch high by a revolving block. To prevent the entrance becoming clogged with ice during the winter there should be no projecting ledge beneath it. To be buried by snow does no harm to the bees during the winter but it is sometimes advisable to clear the entrances during the latter part of March when the snow is very deep, and to see that the entrances are not clogged with dead bees.

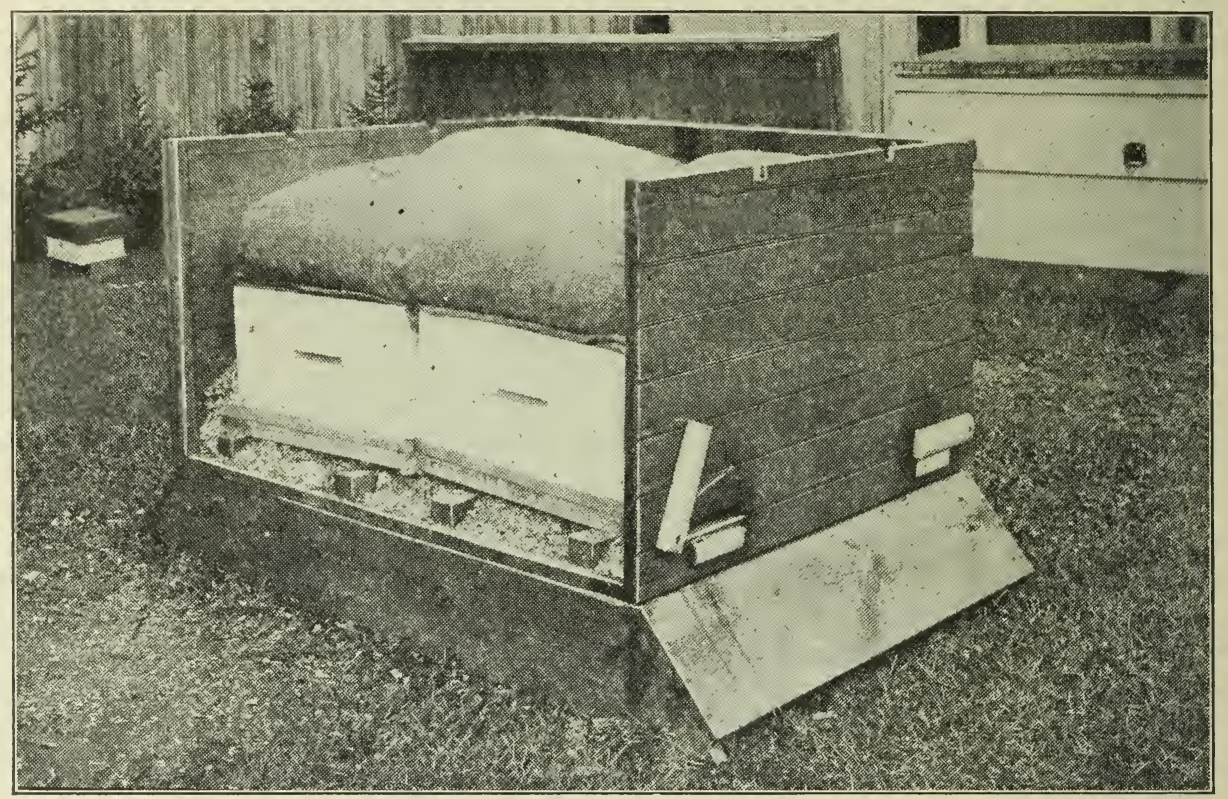

FIG. 42.-Wintering case for four hives, with side removed.

The colonies should be placed in the cases during the latter part of September or early in October and packed on the bottom and all four sides. The bees should then be given the required amount of stores as rapidly as possible. After the feeding is done the top packing should be given, this can be handled better if it is in the form of a cushion. The quilts can be left over the frames or empty bags spread over them, the hive covers, however, should be removed.

Bees wintered out-of-doors must be sheltered from wind. Protection from wind is especially important during the winter and is also advantageous during summer. If the apiary is not surrounded by evergreens or other satisfactory shelter a board fence about eight feet high should be erected around the apiary. The boards should not be tight-fitting but a space of about one inch should be left between each board. It is necessary to emphasize the importance of wind protection in the winter, because it is too often given insufficient attention.

Bees wintered out-of-doors start breeding earlier than those wintered in the cellar, and they benefit by the better protection provided by the wintering cases not only in the spring but in the fall.

\section{CELLAR WINTERING}

The bee cellar should be well ventilated but not draughty, and the temperature should be kept steady at about two to five degrees below that at which the bees would begin to show signs of restlessness. The best temperature in the early part of the winter will usually be around 48 degrees F., but, towards the spring, as the bees become more restless, a somewhat lower one (42 degrees 
F. to 45 degrees $F$.) with more fresh air will be needed. The air in the bee cellar must not be too dry, but it must not be damp enough for moisture to condense on the floors of the hives, and the cellar should be well drained. The bees must be kept in darkness and should be left undisturbed.

The cellar of the residence is usually satisfactory for wintering bees, or it can be made so, the furnace helping to supply the required temperature and ventilation.

A portion of the cellar should be boarded off for the bees. The principal faults in cellars are insufficient insulation to keep the temperature within the stated limits, insufficient ventilation, and insufficient or excessive humidity. The combination of a too low temperature with excessive humidity is particularly injurious.

A bee cellar to contain many colonies should be furnished with an air shaft to draw off the foul air, the draught being regulated by dampers. Good insulation may be secured by having the cellar wholly underground or in the side of a hill, and the fresh air may be brought in through a six-inch or eight-inch earthenware drain pipe laid under the ground.

The bees should be brought into the cellar as soon as possible after the last good flight that they are likely to get. This is usually some time in November. It is advantageous to contract the entrances and give light protection for two or three weeks previously. During transportation to the cellar the entrances to the hives should be temporarily closed with, for instance, soft paper or burlap. Inside the cellar the entrances should be opened to full size to allow sufficient ventilation and to facilitate the ejection of dead bees. The hives may be raised behind slightly to allow the dead bees to roll out. It is a good practice to replace the cover of the hive with three or four empty sacks. The dead bees should be swept out of the cellar two or three times during the winter if they accumulate and become offensive.

The date that the bees should be taken out of the cellar depends upon their condition and the weather. It is usually about the time when the first willows are in bloom, but it may be advisable to bring them out earlier if they are restless and dying fast. They should be brought out when the weather is mild, but too cool for them to fly at once, preferably late in the afternoon of the day before a good flying day is expected. To select the day the forecasts of the Dominion weather service published in the daily newspapers may be helpful.

It is not advisable to winter bees in trenches dug in the ground nor in the upper rooms of houses. Should a colony, through accident, have been put away for the winter light in stores thin cakes of candy, made as explained under "Feeding," should be placed over the frames to avoid starvation, but to have to feed bees in winter is a sign of bad management.

\section{TRANSFERRING}

To transfer a colony of bees from a box hive into a hive with movable combs, the box hive should be moved from its stand and a hive containing drawn combs and one comb of brood should be set in its place. After the bees have been subdued with smoke, pull off part of the top and turn the box upside down. Next irivert an empty box over the top, taking care that the end of the box is even with the back of box hive so that the bees have a continuous wall from the hive into the box; then with the aid of smoke and rapping the sides of the hive drive the bees from the box hive into the box on top, taking care that the queen leaves the old hive. The bees in the box can then be shaken down in front of the new hive. After about two-thirds of the bees and the queen have been drummed out set the box hive behind and with the entrance at right angles to that of the new hive. Twenty-one days later all of the brood in the old hive 
will have emerged when the remaining bees can be drummed out as before and the bees given to the new hive. At this time a young queen may be present and she may either be used for another colony or nucleus or she may replace the old queen that was originally in the box hive. The combs from the old hive may be rendered to wax.

Another method is to tear the top from the box hive and over it fit a movable frame hive containing drawn combs and one of brood. As soon as the queen from the old hive is working in the new hive place a queen excluder between the two hives. Twenty-one days later all the brood will have emerged below when the old hive can be removed and the new hive placed on the old stand.

The best time to transfer colonies is when nectar is coming in as the bees are then less inclined to rob.

To transfer colonies located in hollow trees and other places where the bees cannot be drummed out the cornbs must be cut out with the bees still adhering to them.

Where the combs cannot be got out as, for instance, in the case of colonies located between the walls of a house, a bee-escape may be placed over the hole through which the bees pass in and out. The hive, in which has been placed a frame of brood with a queen and filled with combs is then set up close to the hole. The field bees, being unable to return home, will enter the new hive and these are joined by bees passing out through the escape. In a few weeks' time almost all the bees except the queen will have left their old home and entered the new hive. A gocul bee escape for this purpose may be made from a piece of wire cloth by shaping it into a cone six inches long with a hole at the apex just large enough for one bee to pass. Supers can be given to this colony and in the fall, if the bee escape is removed from the cavity, the bees will rob out the honey and store it in the supers.

\section{UNITING}

In uniting colonies there are several principles to be borne in mind. The bees know the exact location of their hive, consequently, colonies to be united during the active season should stand within eight or ten feet of one another, otherwise bees will get lost. If it is desired to unite two colonies standing further apart, they may be gradually moved towards each other at the rate of two or three feet each day on which the bees fly freely until they stand side by side. In cool weather in autumn when the bees remain for days together in the hives, colonies in different parts of the apiary may be united with only trifling loss. Each colony has its own odour which the bees recognize, so that it is necessary to guard against fighting, especially at times when honey is scarce. At such times robbing, too, has to be avoided, and it is, therefore, advisable to defer the uniting until late in the day. To avoid fighting, both colonies are well smoked, and the combs are arranged in the new hive with a view to mixing the bees as much as possible. The brood combs should be placed in the centre of the hive and the heavier combs of honey at the sides, the combs that are light in weight or otherwise undesirable being left out. From these the bees may be shaken on to a large board leaned against the entrance. The bees usually take good care of the queen, but as a precaution she may be caged in the hive for 48 hours. If both colonies have queens it is advisable to keep the poorer one caged in the hive until it has been ascertained whether the other has been accepted or not.

A simple way to unite colcnies situated in different parts of the apiary in moderately cool weather in the autumn is to place the hive containing the 
weaker or queenless colony on isp of the other with a sheet of newspaper or wire screening between them. When, after some time, the imprisoned bees succeed in gnawing their way through the paper there is no fighting and few return to the old location. If screening is used it should be removed after two days. Five days after uniting the double colony should be examined and all brood placed in the lower story, the upper story being removed.

Swarms that have recently emerged may be united by simply shaking them together.

Should any of the weak colonies be headed with young queens and it is desirable to save them through the winter, two weak colonies may be brought together into one hive. As soon as the weather is cool enough for the bees to cluster in the hive remove five of the lightest combs from each of the colonies

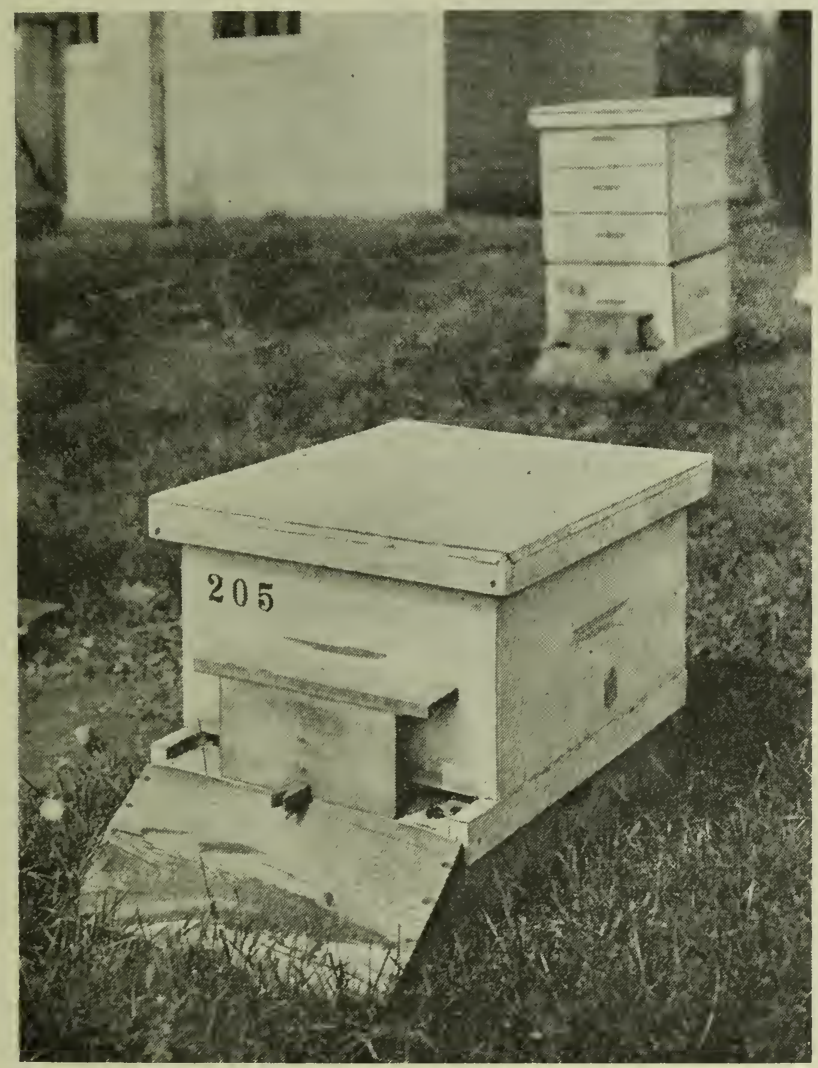

Fig. 43.-Two weak colonies in one hive.

to be brought together, pushing the remaining five combs over to one side of the hive. Two days later place a tight fitting division board in the centre of one of the hives with the combs and bees of that hive to one side of it and then place the five combs and bees from another prepared hive on the other side of the division board. Close the entrance in the centre so as to give an entrance to each side. These double colonies can be safely wintered in the cellar or in cases outside after they are fej. (Fig. 43.) 


\section{REQUEENING}

The queen being the mother of the colony, she is by far the most important bee in the hive. Should she die, leaving no young worker larvæ from which another queen can be raised, the colony will dwindle away unless another queen be given to it. A queen may prove unsatisfactory and require replacing for several reasons. She may be a worthless drone breeder, or she may be unprolific. The prolificness of a quecn is very likely to be reduced after her second year so that she fails to maintain the large population of the colony that is needed for getting a maximum honey yield. Another common reason for requeening is to change the race of the colony from black bees to Italians. If the Italian queen has been mated by a pure Italian drone all the bees in the colony will be pure Italians as long as the queen remains alive.

\section{PURCHASING ITALIAN QUEENS}

In purchasing queens care should be taken to get them from a reliable breeder whose apiary is free from disease. Fertile Italian queens reared during the current year are obtainable from the end of June (earlier if ordered from the southern States) to beginning of October.

In purchasing from a professional breeder of Italians it is usually advisable to order "untested" queens, that is, queens that have been kept only until they have commenced laying, in preference to "tested " queens, that is, queens whose worker offspring have been found to be uniformly banded with yellow to the extent demanded by trade, because the untested queens are less liable to sustain injury in transit, and those sent out by a good breeder are usually purely mated; besides, uniformity in the colour of workers does not prove they are pure.

The queens are sent by mail accompanied by about a dozen workers and a supply of candy in small wooden boxes covered with wire cloth. (See Fig. 44.) Full directions for introducing are also sent with each queen.

\section{QUEEN INTRODUCTION}

Before a queen is introduced into a colony the old queen must be removed. If possible, this should be done from twelve to twenty-four hours, no longer, before the introduction of the new queen. Beginners sometimes experience much difficulty in finding the old queen, especially if she is a black one. When the hive is opened she will be in the brood nest and should be diligently searched for on each comb containing brood before the bees have begun to rush about the hive or gather in knots, which usually occurs after the hive has been open a few minutes. If by this time the queen has not been secured the hive should be closed and another search made a few hours later. As a last resort the queen may be isolated by sifting the bees through a queen excluder placed over the entrance of an empty hive into which the combs are placed after the bees have been shaken off them onto a runway placed in front of the hive.

Precautions have to be taken in introducing the new queen to prevent the workers attacking and killing her. One of the most reliable and widely practised methods of queen introduction is to confine the queen in the hive in a wire cloth cage until she has acquired the odour of the colony. A queen introducing cage may easily be made from a piece of wire screening $2 \frac{1}{2}$ inches square by cutting a half-inch square out of each corner and folding over the sides so formed. This cage with the queen inside is pressed into a tough portion of comb near the centre of the hive. Only one or two of the cells enclosed by the cage should contain honey. The queen should be liberated about forty-eight 
hours later, provided the bees are not clustering closely around her, in which case she is left caged another day or two. The colony should not be disturbed or examined to see if the queen is safe until five days after the queen's release.

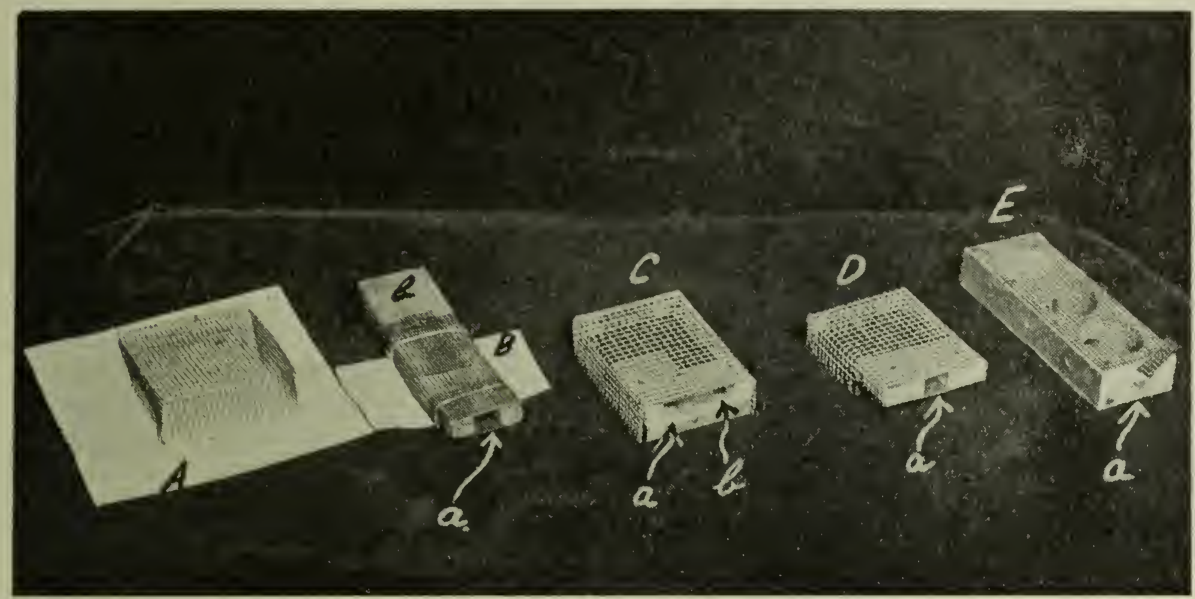

Fig. 44.-A. Push-in cage made of wire screening.

B. Miller introducing cage. (a) Hole for candy. (b) Plug of wood to be removed when placing queen in cage.

C. \& D.-Combination cage for pushing into comb and which will allow for bees to release queen. (a) Long hole for candy. (b) Short hole for candy and covered on inside by piece of zinc excluder.

E.-Mailing cage. (a) Hole for putting queen into cage.

Another very good queen-introducing cage is the "Miller" introducing cage, which contains a hole plugged with candy. The bees will usually eat through the candy in about twenty-four hours, and will thus release the queen automatically without any disturbance of the bees by the beekeeper. To delay the release of the queen the candy may be kept covered during the first twentyfour hours with a piece of wood or tin. The candy is made by mixing powdered sugar and honey into a stiff dough. The travelling cage in which the queen is mailed is usually adapted for use as a candy introducing cage, and it is often used in commercial apiaries to save trouble, but it is safer to take the queen out of the travelling cage and introduce her alone, or with a few recently emerged workers from the hive in a new cage. As a precaution against introducing disease the mailing cage and workers may be destroyed.

Queens are less liable to be attacked and killed by the workers after introduction during a honey flow than during a honey dearth. The period immediately after the honey flow when robbers are prowling about should, if possible, be avoided for introducing queens. In autumn the colony should be well supplied with food before the queen is liberated.

If the colony has been queenless for more than three days, all queen cells should be cut out at the time of caging the queen in the hive. If eleven or more days have elapsed since the colony lost its fertile queen and young brood was in the hive, one or more virgin queens will be present and must be found and killed before the queen is introduced.

\section{REARING QUEENS}

Too little attention has been paid in Canada to queen rearing. A large apiary kept for honey production possesses all the best conditions for the successful rearing of queens and frequently also for obtaining a high percentage of matings with drones of selected parentage for the improvement of stock.

Space forbids giving more than an outline of the process. 
Beginners may save queen cells from their best colonies that swarm, breaking up the colony into several little colonies or nuclei shortly before the young queens are due to hatch, each nucleus consisting of two combs containing brood with adhering bees, honey and a queen cell. Spare queen cells may be given to other nuclei specially formed to receive them.

However, it is better to rear queens from the best colonies that do not swarm. This may be done by transferring with the turned-up point of a sharpened quill or special grafting tools about twenty young worker larvæ of the desired parentage into artificial (or natural) queen cells and giving them to a colony that has been queenless for several hours and from which all open brood has been removed. The colony should contain plenty of young bees for feeding the larvæ. The larvæ used for the cells should not be more than about two days old. The artificial queen cells may be made by dipping the rounded and moistened tip of a wooden stick three-eighths of an inch thick into melted wax to a depth of one-half inch three or four times, the cups so formed being afterwards fixed on to the edge of a narrow board which is suspended in the hive. Handy queen cell cups that can be used repeatedly may be made by hollowing out one end of a short cylinder of wood to the size of a queen cell base and lining it with wax. The bases of the cups are fastened to the edge of the board by means of projecting nail points. The operation of transferring the larvæ is carried on during the honey flow, and care is taken to see that the larvæ are

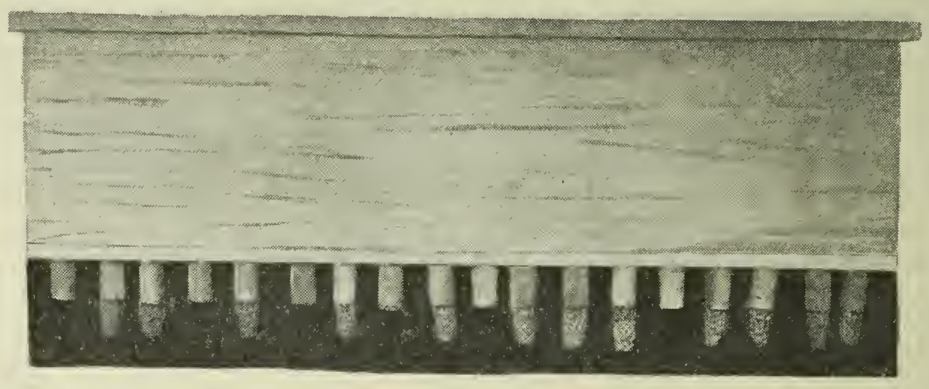

FIG. 45.-Carrier of queen cells.

continuously supplied from the time of transference with an abundance of brood food. For this purpose the cups may be primed with food from an uncapped queen cell, just before the larvæ are transferred to them. The young bees are then more likely to accept them and to supply the young larvæ with plenty of food. On the tenth morning after the transference of the larvæ the queens will be due to emerge in a few hours and the queen cells should be distributed to nuclei. Cell protectors made of wire wound in a spiral with a hole at the tip of the cell through which the queen will emerge may be used. These protectors prevent the bees from tearing open the sides of the cell. In due time the queen in each nucleus will get mated, provided no accidents occur, and she may be introduced to any colony requiring a queen at any convenient time thereafter. 


\section{FEEDING}

The various occasions on which feeding is necessary or advisable have been mentioned under "Spring Management," "Swarming," and "Wintering," and only a few remarks on how to make and give the food are here necessary.

Syrup made from the best grade of white granulated sugar is a cheap and safe substitute for honey in spring and summer, and a desirable supplementary food for winter.

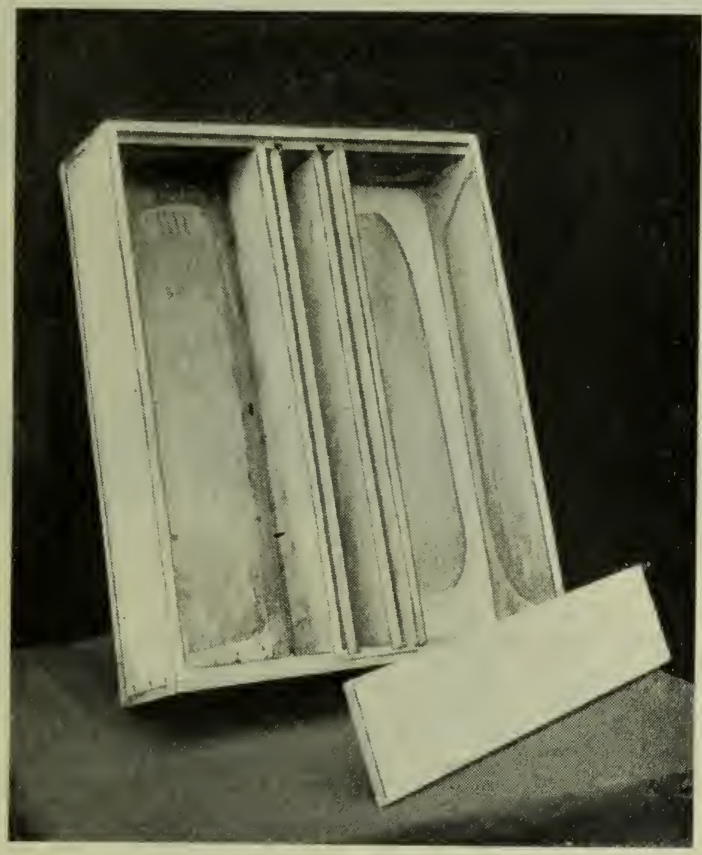

Fic. 46.-Miller Feeder.

For spring and summer feeding, two parts by measure of sugar stirred into three or four parts of water until dissolved make a satisfactory syrup to carry the bees over a period of dearth.

For autumn feeding, use two parts of sugar to one of water. To get the sugar to dissolve completely in the case of autumn syrup the water must be hot. If the syrup is made over the fire the sugar must be added to the water in small quantities at a time and kept constantly stirred until dissolved to prevent it from settling on the bottom of the vessel and burning, because burnt sugar is very unwholesome for bees and would cause their death during the winter. The best method is to first bring the water to a boil and then remove it from the fire and immediately stir in the required amount of sugar until it has all dissolved.

Syrup made as described above should be given inside the hive and coverer up so that bees from the other hives cannot get access to it. To prevent undue excitement and robbing, it is best to feed in the evening.

There are many kinds of bee feeders. For stimulative feeding in the spring and summer, a good one is a five-pound pail with a few small holes punched in the cover. For rapid feeding in autumn there is nothing better than a tenpound honey pail with thirty or forty holes punched in the cover, or the Miller feeder, which consists of a wooden box so constructed that the bees cannot get drowned. (Figs. 46 and 47.) These are placed on top of the frames and an empty super or extension will be needed to cover it. 
Having to feed bees during the winter is a sign of bad management, but should such an emergency arise candy made as follows and placed over the frames beneath the quilt will often save a colony from starvation:-

Dissolve three pounds granulated sugar in one pint of boiling water. After sugar has dissolved bring to a boil over a slow fire and boil till it reaches 280 degrees Fahrenheit or when the candy will form hard brittle strings when dropped

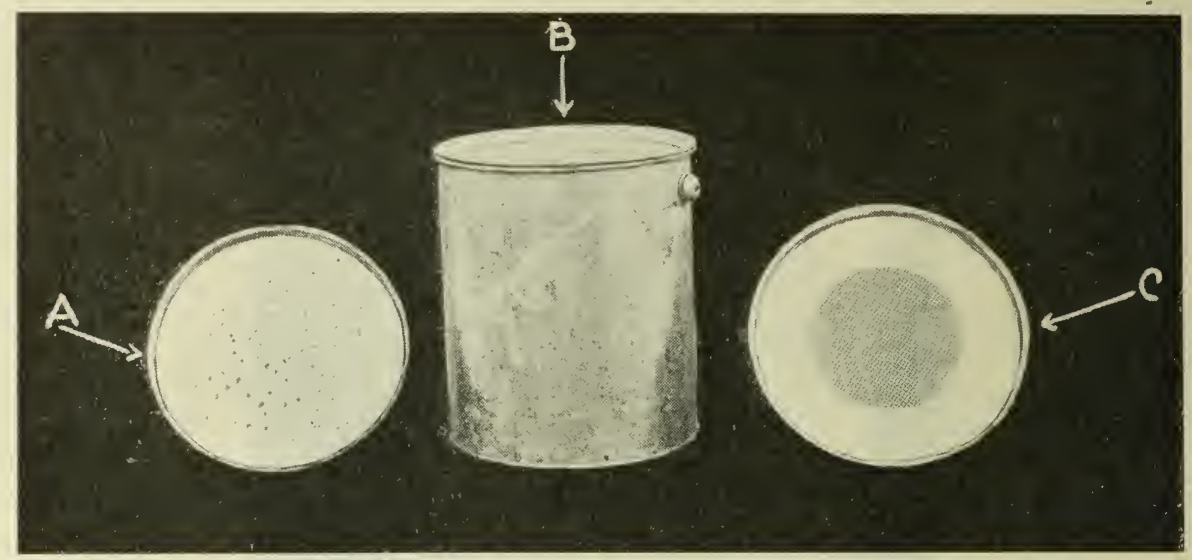

Fig. 47.-Honey pail feeder. (a) Ordinary cover punched with shingle nail. (b) 10-pound pail fitted with special cover. (c) Special cover supplied by manufacturers.

into cold water. Pour into moulds and allow to harden. Do not disturb the candy after pouring or scrape it from the dish in which it was boiled into the mould or it will crystallize. When hard the candy should be light amber in colour and transparent.

Care should be taken not to burn or scorch the sugar when cooking.

\section{ROBBING}

In warm weather when there is little or no honey to be got from the flowers the bees will easily yield to any temptation to obtain it by any other means that come in their way. After more or less fighting they will overpower any very weak colonies, especially those that are queenless and will carry the honey to their own hives. Robbing may also be started by the carelessness of the beekeeper during manipulation, especially when removing the honey or feeding.

During a honey dearth the beekeeper should in all his work carefully avoid doing anything that will excite robbing, for robber-bees are a constant annoyance and danger in the apiary.

No colony should be allowed to grow weak and no honey or syrup should be exposed in the apiary. If robbing has begun the attacked colonies should have a bunch of wet grass or weeds thrown over the entrance. Hives should be opened as little as possible, and then only during the hour before sunset or early in the morning or under a bee tent. Robbing is most likely to be troublesome in the late summer during the decline of, and immediately after, the honey flow. It is advisable at this time to contract the entrances of all hives. One can tell if a colony is being robbed by seeing the robbers enter hurriedly with the abdomen contracted and leave with the abdomen distended, flying straight home. Old robbers have a shiny appearance, the hair having become rubbed off. The extracting should only be done in a bee-tight house and combs and honey should also be stored where the bees cannot reach them. 


\section{BEE DISEASES}

Five bee diseases are known to occur in Canada-three affecting the brood, namely, American foul brood, European foul brood and Sacbrood; and two affecting the adult bee-paralysis and dysentery.

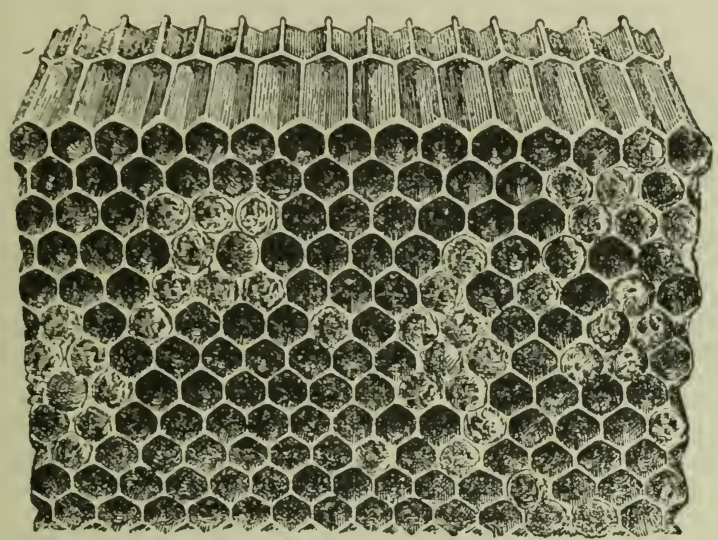

Fig. 48.-American foul brood comb showing irregular cappings and scales. The position of the comb ind cates best way to view the scales. (Phillips, F'armers' Bull. No. 442. U.S. Dept. Agric.)

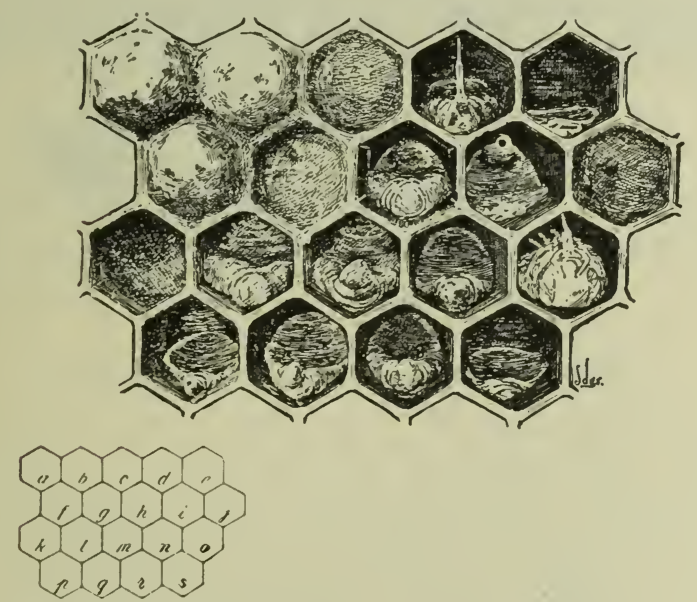

Fig. 49.-American foul brood; a, b, f, normal sealed cells; $c, j$, sunken cappings, showing perforation; $g$, sunken capping not perforated; h, l, m, n, q, r, larvæ affected by disease; e, $i, p, s$, scales formed from dried-down larvæ; d, o, pupae affected by disease. Twice natural size. (Phillips, Farmers' Bull. 442. U.S. Dept. Agric.)

American foul brood and European foul brood are serious diseases which have caused enormous loss to the beekeepers of Canada They are highly infectious, but by proper treatment they can both be controlled and their spread checked It is, therefore, important that every beekeeper should acquaint himself with the symptoms of foul brood and the proper methods of treatment and should keep a careful watch for its appearance in his apiary. 


\section{AMERICAN FOUL BROOD}

This disease affects principaily the larvæ just after they have been capped over. In a colony suffering from American foul brood the cappings of some of the cells are seen to be discoloured and they may be sunken, irregularly perforated or removed altogether. If these affected cells be examined it will be found that the larvæ in many of them have sunk down in the cell and have become a coffee-coloured and viscid mass. If a match or toothpick be inserted into the cell the rotting mass adheres to it and can be drawn out into a string an inch or two long. Affected pupæ usually have the tongue adhering to the upper wall of the cell. There will often be other cells in which the decayed larvæ has dried down to a scale which adheres tightly to the lower wall of the cell. In a badly affected colony a disagreeable odour is usually noticeable. The colony grows weak through the diminishing number of emerging bees and usually dies sooner or later. Queen or drone larvæ are rarely affected.

American foul brood is rather widely distributed in Canada having been found in most of the provinces.

\section{EUROPEAN FOUL BROOD}

In European foul brood most of the larvæ are attacked and die before the cell is capped over, usually while very small, but a few capped larvæ are often affected also. In most cases the larvæ loses its plump shape and lies in the

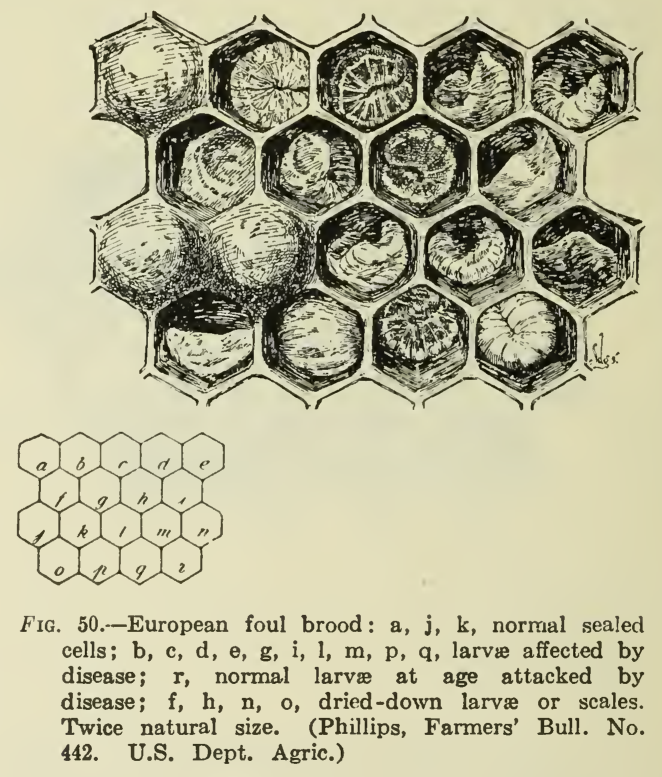

bottom of the cell, a shapeless collapsed mass, giving the appearance of being melted, and its colour changes from pearly white to yellow or grey. Others do not have this melted appearance but dry up into a greyish coloured scale at the bottom of the cell. These larvæ retain their curled up position and have a segmented appearance due to the trachæ showing through the skin. The decaying larvæ are usually not ropy as in American foul brood, but a slight ropiness may be observed due to the presence of other organisms.

Queen and drone larvæ are quickly attacked by this disease, as well as the worker brood. The scale to which the larvæ eventually dries down does not adhere to the cell, and most of these scales are carried out by the bees. A slight, 
sour odour is usually present in cases of this disease, and a disagreeable odour of putrefaction is also sometimes noticed. The symptoms of the disease are more variable than those of American foul brood. European foul brood is most destructive in late spring and early summer before the honey flow. During the lioney flow it disappears, to return in the fall or the following spring. It spreads through the apiary and district more rapidly than American foul brood.

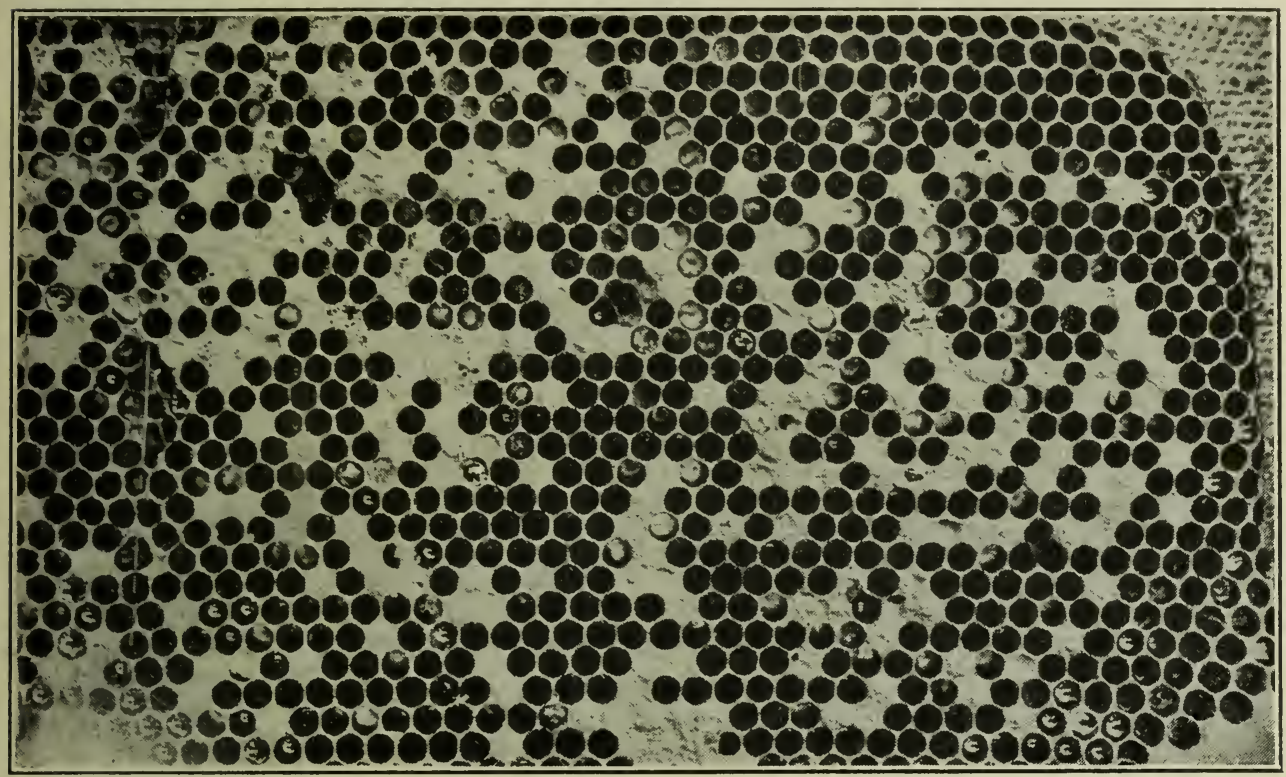

Fic. 51.--European foul brood.

Black bees are more susceptible to European foul brood than Italians, but both races are equally susceptible to American foul brood. Neglected apiaries of black bees quickly die out when attacked by European foul brood, and many a careless beekeeper has been put out of business by it.

\section{METHODS OF SPREADING FOUL BROOD}

Both American foul brood and European foul brood spread from colony to colony and from apiary to apiary in much the same way. An affected colony becomes very weak or dies. The hive is robbed and the honey containing the germs of the disease is carried by the robbers to their own hives. The beekeeper may unwittingly aid the spread of the disease by feeding the bees with infected honey or by putting swarms into hives or upon combs that have come from diseased colonies. Discarded receptacles that have contained honey from a diseased colony, if not thoroughly cleaned, may also be a source of infection.

\section{PREVENTIVE MEASURES}

The following precautionary measures are recommended for adoption by all beekeepers: Never purchase colonies of bees unless it is certain that they are fre:? from disease. Never feed bees with honey of unknown origin. If the bees need feeding give sugar syrup, not honey. Do not purchase old combs, used hives, or second hand bee supplies unless it is certain that they came from healthy apiaries. Keep all colonies strong. The disease should be explained to neighbouring beekeepers, and they should be invited to co-operate in its prevention and treat- 
ment. Such practices as leaving colonies to die on their stands and exposing combs of honey taken from colonies that have died for the bees to feed upon are very bad beekeeping, and may result in all the apiaries in the neighbourhood becoming diseased. Those who keep bees in box hives should be urged to transfer them to hives with movable combs.

\section{TREATMENT OF AMERICAN FOUL BROOD}

The treatment of American foul brood consists in the removal and destruction of all infected matter and compelling the colony to make a fresh start by building new combs and gathering fresh stores.

The bees should be treated, if possible, during the honey flow so that the other bees in the apiary will not be inclined to rob, and also that the treated bees may make a good start. If no honey flow is taking place, the newly treated bees will need feeding with syrup. To further reduce the risk of robbing the work should be done towards evening unless the number of colonies to be treated is great. To facilitate rapid handling the frames in the colonies to be treated may be loosened the day before treatment is given. Before treatment is begun everything required should be in readiness.

One new hive must be ready, containing nine frames fitted with full sheets of foundation, and one dry comb which should be in the centre of the hive. An empty hive should also be ready to receive the diseased combs. The colony should be lightly smoked and removed from the stand, upon which should be then placed the new hive. Bees should be transferred from the diseased colony by being shaken or brushed from the combs on to large sheets of paper directly in front of the new hive Infected combs should then be placed in the empty hive and covered. All infected material should be moved to a bee-tight building and the paper on which the bees were shaken and the brush or wing used to brush them from the combs, should be burned.

Twelve hours after the bee: are transferred, remove the drawn comb from the new hive and burn it, replacing it with a full frame of foundation.

If several colonies are affected and have become weak they can be strengthened by uniting two or more colonies two weeks before treatment is given.

Where only a few colonies are treated the safest plan is to burn all infected combs, and thus safeguard against the disease spreading. Where a large number of colonies are treated, the combs can be boiled down and the wax extracted, but bees must not be allowed to gain access to the infected combs, or reinfection of the whole apiary may take place. Hive bodies, floor boards and covers can be disinfected by lightly burning orer the inside surfaces. A gasoline torch is most suitable for this purpose.

Some beekeepers may prefer the older method which consists of first shaking the bees on to starters of foundation and three days later again shaking them on to full sheets of foundation. The second shaking, however, often discourages the bees and causes them to swarm; therefore, the dry comb method is preferable. Where the beekeeper has no dry combs the other method must be used.

If the colonies are found affected in the fall and the beekeeper has some full combs of honey from healthy colonies, the bees can be transferred to these combs in a new hive by shaking the bees on to sheets of paper in front of the hive and allowing them to run in. All combs from the diseased colonies must be destroyed and all hives disinfected by burning. The best time for this treatment is early in the fall when the bees are still flying, but care must be taken to prevent robbing.

All short-cut methods for treatment of colonies affected with American foul brood should be avoided. They may prove successful in the hands of an expert, but he is the least likely to employ them. In fact many beekeepers who 
find an occasional colony affected with American foul brood prefer to take no chances, but suffocate the bees and then burn the contents of the hive. This is a sure cure and is the safest plan to prevent the spread of the disease.

\section{TREATMENT FOR EUROPEAN FOUL BROOD}

Manipulation as for American foul brood has little or no effect on European foul brood. Good beekeeping methods are preventive measures and if these are carried out European foul brood should not cause much alarm. Losses from this disease will be reduced to a minimum if weak and queenless colonies are united in the spring and only strong colonies, headed with Italian queens from good resistant stock, are kept, together with plently of wholesome stores for the winter. If the disease does occur in strong colonies it seldom becomes serious. If the disease is already present it may be controlled by making the colonies strong by uniting and introducing young Italian queens from resistant stock to all infected colonies. This should be done in the early spring, as most of the damage is done during the spring and early summer. There is no need to destroy or disinfect any combs or supplies when dealing with European foul brood.

\section{SACBROOD}

This disease seldom causes any serious losses among the bees. Colonies may become weakened and the honey crop may be affected, but a colony is seldom killed outright by it. To the inexperienced the symptoms of Sacbrood may be confused with those of American or European foul brood. The disease usually appears during the spring and early summer, disappearing again shortly. There are few cases in the summer when the main honey flow is on.

Both sealed and unsealed larvæ may be affected with this disease. Larvæ dead from sacbrood will usually be found stretched out along the lower wall of the cell and often with the anterior end turned up towards the upper wall. The colour changes from a pearly white and may vary from yellow to dark brown or grey. The skin of the larvæ becomes toughened so that the dead mass may be lifted out like a small sac, the contents of which are watery. Queen and drone larvæ may also be affected.

\section{TREATMENT FOR SACBROOD}

The disease is of such a character that where only strong colonies headed with vigorous queens, and good beekeeping methods are practised, no other treatment is necessary. If a colony becomes weakened and the disease is persistent, a young vigorous queen should be introduced.

\section{OTHER AFFECTIONS OF THE BROOD}

Brood may die from various causes other than disease. It may get chilled or starved. When the honey flow is suddenly stopped by the onset of unusually cold weather the bees will destroy a large quantity of drone brood and sometimes also worker brood. Such dead brood is soon removed by the bees.

Another condition that may be mistaken for disease is what is known as bald headed brood, in which the pupæ are uncapped or only partly capped. If the uncapped cells are in lines it may be suspected that wax moth larvæ are working in the combs, but if the uncapped cells are mixed or scattered and the pupæ are seen to be normal there is nothing seriously wrong.

\section{DISEASES OF ADULTS}

Among the few adult bee diseases in Canada, dysentery is the most important. Dysentry is caused by the consumption of unwholesome stores such as honey 
dew, dandelion honey and often by late gathered honey, a:ıd by the bees retaining the fæces within the intestines for an unnatural length of time. Dysentery is more prevalent during the early spring just after the long confinement during the winter. Dysentery may also be caused by any undue excitement within the hive during the winter, or by late fall breeding when the young bees are unable to take a flight before going into winter quarters. After one or two good flights, however, the disease soon disappears. Healthy bees eject their fæces during flight, but during the months of winter when flight is impossible the fæces will accumulate in the intestines, in some cases to such an extent that it will be voided inside the hive and the combs and hive will become badly stained. A disagreeable odour is always present with dysentery.

The beekeeper should see that his bees go into winter quarters with plenty of wholesome well-ripened honey, and also that the bees receive no excessive disturbance from the time they are placed away for the winter until they are brought out in the spring. Where the honey in the hive is of uncertain quality, it is well to feed the bees with 15 to 20 pounds of sugar syrup in the fall.

Disappearing Disease and Paralysis are names given to obscure diseases, which usually appear in the apiary during the spring and early summer, or after a long spell of wet weather. Only in ::ire cases do they persist during the entire season.

The infected bees appear to be paralyzed. They can only fly a few feet, falling to the ground and after crawling about for a short time they soon die. The abdomen is usually distended, as in cases of dysentery. Infected colonies may become seriously weakened, but seldom die out entirely. A colony showing symptoms of disease one year may be entirely free from it the following season. These diseases do not appear to spread rapidly; one colony in an apiary may be affected without others becoming infected. The treatment recommended is strong colonies headed by young, vigorous queeis. Very little is known of these diseases and further investigations may reveal other diseases now classified under these names.

Nosema Apis.-This disease is caused by a small parasite invading the alimentary canal of the bee, and although it has been found in Canada, this disease does not appear to be of very great importance.

Isle of Wight Disease.-So far this disease has not appeared in Canada or the United States but beekeepers are warned to keep a careful watch for its appearance. Adult bees only are affected. All beekeepers who discover any signs of disease in adult bees should send samples at once to the Bee Division, Central Experimental Farm, Ottawa.

\section{ENEMIES OF THE BEE}

Wax Moth.-The larvæ of the Wax Moth (Galleria mellonela) are found in neglected apiaries where they destroy the combs and brood of weak colonies, and also the combs of colonies that have died out, lining the tunnels they make in the combs with a silky web. They will also get into the stored combs and destroy them. Colonies that are strong and well looked after resist the depredations of wax moth. The full grown caterpillar is about one inch in length and it spins an oval white cocoon in some crevice in the hive where it changes to the chrysalis. As the different stages of wax moth are killed by severe cold (11 ${ }^{\circ}$ F.) it is a good plan to store combs for the winter in the honey house and not in the cellar. All spare combs should be looked over and, if wax moth larvæ are present, given to the bees, or fumigated. To fumigate combs they should be placed in hives tiered one above the other with an empty hive or super on top In this super is placed a saucer containing bisulphide of carbon, the fumes of 
which, being heavier than air, settle down through the combs. Care should be taken not to bring a flame near, as the fumes are highly inflammable. Sulphur fumes may be used instead. Colonies affected with brood disease are very likely to become the prey of wax moth in the last stages of their existence.

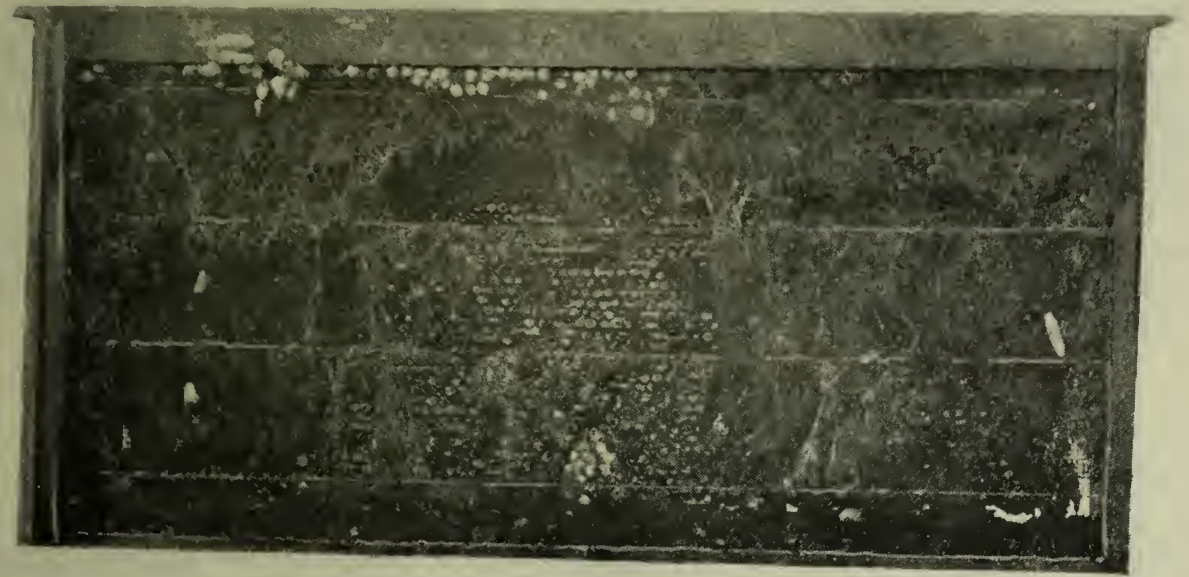

Fig. 52.-Comb destroyed by wax moth.

Other Enemies.-Amongst other enemies of the bee may be mentioned wasps, toads and certain birds. These do no serious harm to strong colonies. Mice and rats, however, will sometimes destroy colonies in the winter if care is not taken to exclude them from the bee cellar or wintering case. Colonies

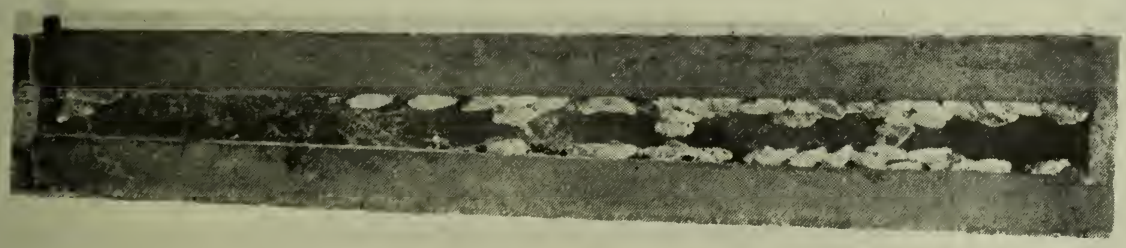

Fig. 53.-Cocoons of wax moth.

wintered outside may be protected by reducing the width of the entrance to three-eighths of an inch so that mice are unable to get in. In the cellar they can be poisoned. In storing combs for the winter a metal cover should be placed beneath and above the supers containing them. This will prevent damage from these pests. 


\section{BEE DISEASE LEGISLATION}

Owing to the severe losses of bees in Europe due to the Isle of Wight disease the importation of adult bees, second-hand supplies, etc., from Europe are prohibited under the following Ministerial Order issued May, 1923:-

\section{Department of Agriculture, Canada}

\section{Deputy Minister's Office, Ottawa.}

Under and by virtue of the authority conferred upon me by the provisions of the Order in Council of November 30, 1909, containing regulations relating to Animals' Quarantine, issued under authority of Edward VII, I do hereby order that:

On and after the 1st day of May, 1922, the importation into Canada of bees, used or second-hand hives, or raw hive goods or products, excepting honey or wax, from the continent of Europe, is hereby prohibited owing to the danger of introducing a contagious disease of bees known as "Isle of Wight" disease.

Dated at Ottawa, this twenty-second day of April, 1922.

(Sgd.) J. H. Grisdale, Deputy Minister of Agriculture.

The following provinces now have foul brood acts: Prince Edward Island, Nova Scotia, New Brunswick, Quebec, Ontario, Manitoba and British Columbia.

Under these Acts inspectors are employed to inspect any apiary within the province and to report to the Minister of Agriculture or the Provincial Apiarist. Beekeepers in the above-mentioned provinces are advised to write to their Provincial Apiarist asking for a copy of the Provincial Act.

\section{BEES AND FRUIT}

The value of bees as pollinators in orchards has already been referred to in the discussion upon the advantages of beekeeping.

Complaints are sometimes made of the poisoning of bees as the result of their visiting fruit bloom that has been sprayed with insecticides. Fruit trees should never be sprayed with poison while in full bloom, as insects visiting the flowers will be killed and in this way the proportion of fruit that will set will be reduced. Some of the provinces now have laws forbidding the use of sprays containing poison while the trees are in bloom.

The recent use of dust for dusting fruit trees is causing heavy losses to beekeepers, especially in Nova Scotia. The dust evidently falls on other plants that are blooming at the time of dusting and the bees gather the poison and die off in large numbers. The young brood is also killed through the poisoned food given them. At the present time the only remedies that can be suggested is the cutting of all other bloom in the orchards or by the use of some repellant in the dust used. As the dust, is carried long distances by air currents the former method would only partially overcome the difficulty.

Bees may, at times, be seen feeding on ripe plums and other sweet fruit, and this has led some fruit growers to fear that they may damage fruit. Experiments conducted in the apiary of the Central Experimental Farm in 1901, and elsewhere, have shown conclusively that bees do not injure sound fruit. It is only when the skin has been broken by birds or wasps or in some other way that the bees suck the fruit juices. 


\section{BEEKEEPERS' ASSOCIATIONS}

Beekeepers, like the members of any calling, are greatly helped by getting into touch with one another for the exchange of ideas and the discussion of problems relating to their welfare.

Most of the provinces now have a provincial or parent association. Within some of the provinces are many local or county associations that are affiliated with the larger associations. These societies are doing excellent work for the advancement of the industry. Some of them have started co-operative buying of bees and supplies and selling of honey to the benefit of their members. The members are also able to receive various bee journals at club rates. Every beekeeper should endeavour to join his nearest association and receive the benefits that can be derived from it. The Provincial Apiarist will be able to give the names and address of the secretaries of the various local associations in the different provinces.

\section{PUBLICATIONS ON BEEKEEPING}

No beekeeper should be without a book that treats in fuller detail than can be done here the different features of beekeeping. The following are standard works:-

"The ABC and XYZ of Bee Culture," by A. I. and E. R. Root. Published by the A. I. Root Co., Medina, Ohio, U.S.A. An attractively written and profusely illustrated encyclopedia of all the phases of practical beekeeping. Toronto.

"Beekeeping," by E. F. Phillips, Ph.D. Published by the Macmillan Co.,

"Langstroth and the Honey Bee," by Dadant, Hamilton, Ill., U.S.A.

"Productive Beekeeping," by Frank C. Pellet. One of Lippincotts farm manuals.

"A Thousand Answers to Beekeeping Questions," by Dr. C. C. Miller.

"Out-apiaries," by C. P. Dadant, Hamilton, Ill., U.S.A.

"Practical Queen Rearing;" by Frank C. Pellet.

"First Lessons in Beekeepıng," by Dadant.

"Scientific Queen Rearing," by Doolittle.

"How to Keep Bees," by Anna B. Comstock. Published by Doubleday, Page \& Co., New York, U.S.A.

Any of the above text books can be had from most of the bee supply houses or from the authors.

Several bee journals are published which keep the beekeeper in touch with current events and progress, and give helpful hints, and also information about the doings and personality of beekeepers, and about the meetings of the various beekeepers' associations. Canadian beekeepers will find much interesting and helpful information in any of the following journals: "The Beekeeper" published monthly at Peterborough, Ont.; "Les Abeille," published monthly by the Department of Agriculture, Quebec; " The American Bee Journal," published monthly at Hamilton, Ill., U.S.A.; and "Gleanings in Bee Culture," published monthly at Medina, Ohio, U.S.A. 


\section{BEEKEEPING AT THE DOMINION EXPERIMENTAL FARMS}

Bees are now kept at twenty of the Dominion Experimental Farms, namely, the Central Experimental Farm, Ottawa, and the following branch Farms: Charlottetown, P.E.I.; Nappan, N.S.; Kentville, N.S.; Fredericton, N.B.; Ste. Anne de la Pocatiere, Que.; Lennoxville, Que.; La Ferme, Que.; Kapuskasing, Ont.; Morden, Man.; Rosthern, Sask.; Scott, Sask.; Lethbridge, Alta.; Lacombe, Alta.; Beaverlodge, Alta.; Fort Vermilion, Alta.; Invermere, B.C.; Summerland, B.C.; Agassiz, B.C.; and Saanichton, Vancouver island, B.C.

At all these stations with the exception of Beaverlodge, and Fort Vermilion, Rosthern, and Scott, where the bees have not been kept sufficiently long to produce definite results, beekeeping has been found to be profitable. At Lethbridge, alfalfa has proved the principal source of surplus honey. At Morden, Lacombe, and Invermere the sources are mixed. At the remaining stations alsike and white clover are the principal but by no means the only sources

\section{CONCLUSION}

In the foregoing pages an endeavour has been made to present briefly the main features of successful bee management in as concrete a form as possible. It may be well in conclusion to summarize the most important points in a few words.

The bee year may be said to commence in the autumn, and success the following season depends very largely on the proper preparation of the bees for winter, followed by careful and systematic spring and summer management. Colonies should be kept strong and every queen that is not prolific and does not produce industrious and hardy workers should be replaced. A sufficient supply of standard hive parts, frames and foundation to meet all possible needs should be procured and made up before the busy season. To the message "better keep bees" we would add with greater emphasis the one "keep bees better." The successful beekeeper is the one who has learnt how the bees will act under various conditions and how these conditions and the actions of the bees can be controlled. 


$$
\text { - }
$$




CALBCA OTTAWA K1A OC5

The following publications of the Department of Agriculture relating to Beekeeping are available on application to the Publications Branch, Department of Agriculture, Ottawa:-

Wintering Bees in Canada, Bulletin 22, New Series.

Beekeeping in Canada, Exhibition Circular 18.

Facts about Honey, Exhibition Circular 51.

Bee Diseases, Exhibition Circular 105. 
OTTAWA

F. A. ACLAND

PRINTER TO THE KING'S MOST EXCELLENT MAJESTY 1923 